\title{
BIOCHEMICAL AND MOLECULAR CHARACTERISATION OF THE PROPOSED P2Y 1 -P2Y 12 RECEPTOR HETERODIMER IN TSA201 CELLS
}

by

SAMUEL DAVIS

A thesis submitted in partial fulfilment for the degree of Master of Research in Pharmacology 
'This thesis is the result of the author's original research. It has been composed by the author and has not been previously submitted for examination which has led to the award of a degree.'

'The copyright of this thesis belongs to the author under the terms of the United Kingdom Copyright Acts as qualified by University of Strathclyde Regulation 3.50. Due acknowledgement must always be made of the use of any material contained in, or derived from, this thesis.'

Signed:

Date: 


\section{Acknowledgements}

I would like to extend my thanks and gratitude to everyone who has assisted me in various ways through this year long project, and helped to make it a most enjoyable and rewarding time that I shall never forget and would happily do again without hesitation.

To my supervisor, Dr Charles Kennedy, I would like to thank him for putting together this project, and for teaching me the fundamentals of cell culture, transfection and $\mathrm{Ca}^{2+}$ imaging. His enthusiasm for the project helped drive me to get the most out of it, and I am especially grateful for having access to his advice and experiences about purinergic signalling.

To my co-supervisor Dr Margaret Rose Cunningham, thanks greatly for teaching me the biochemical techniques (especially the co-IP), furthering my knowledge/experience of cell culture/transfection and for your many encouraging suggestions of ways and directions in which I could further expand on the data that I was obtaining. Thanks also for all of the interesting discussions that we had, both related to the project and to various other topics.

I would also like to extend an especial thanks to $\mathrm{Dr}$ Rothwelle Tate, for his patience, understanding and expertise whilst training and mentoring me in the molecular biology related techniques, and for answering all of my many questions - plus also for putting up with me continuing to work in his lab area for so long!

Thanks also to Graeme for guiding me through setting up and running the platereader $\mathrm{Ca}^{2+}$ assay, and also for the rest of your help with the Western blotting and various other experiments in the lab area. All the best for the rest of your PhD.

To Moa, good luck with continuing the investigation of the proposed dimer during your $\mathrm{PhD}$, I wish you the very best.

To anyone else not mentioned who provided materials, reagents, advice and other resources or support, thank you very much!

Lastly, to my Mum and Dad, thanks for your continuing support during the last year, which I could not have done without, especially when writing this thesis. 


\section{Table of Contents}

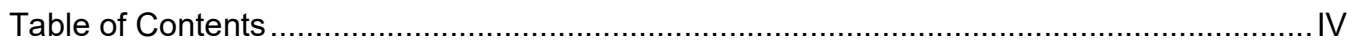

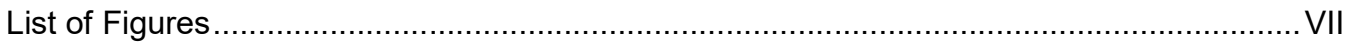

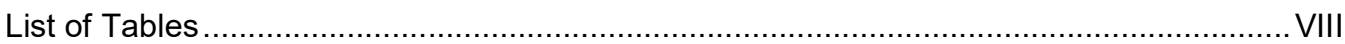

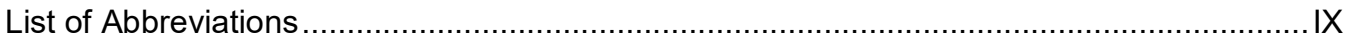

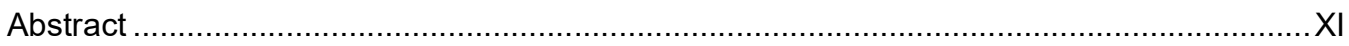

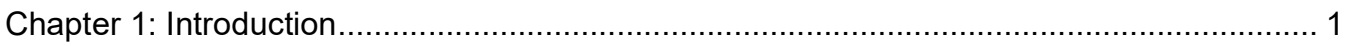

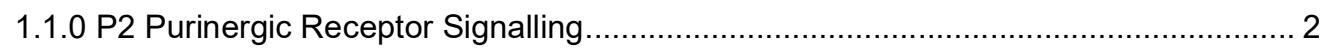

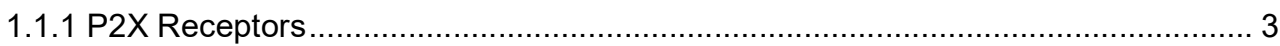

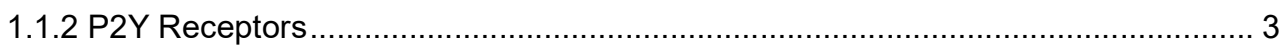

1.1.3 Human $P 2 Y_{1}$ and $P 2 Y_{12}$ Receptor Tissue Distribution ....................................... 5

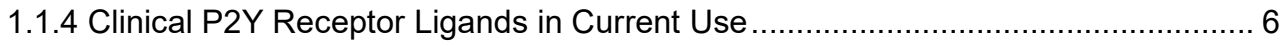

1.1.5 Cell Lines Used for In-vitro P2Y Receptor Studies................................................ 6

1.2.0 The Role of the Purinergic System in Pain ............................................................... 7

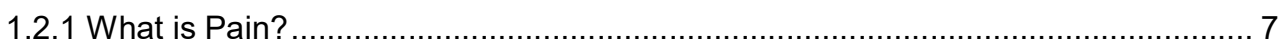

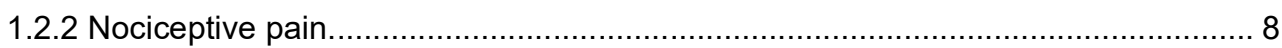

1.2.3 Inflammatory Pain: the Development of Peripheral and Central Sensitisation........ 9

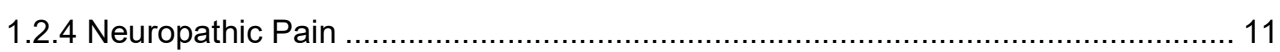

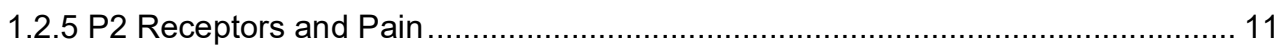

1.3.0 G Protein-Coupled Receptor Dimerisation ....................................................... 13

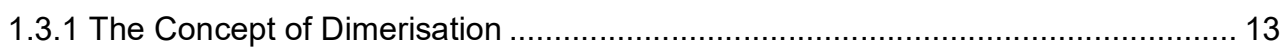

1.3.2 A Brief History of Dimerisation and Research Techniques ............................... 14

1.3.3 The Dynamic Nature of Dimerisation ............................................................. 17

1.3.4 Functional Examples of GPCR dimers ...................................................... 17

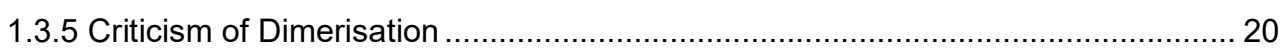

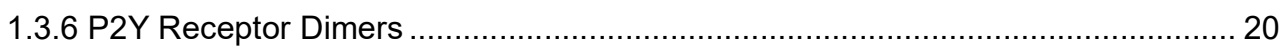

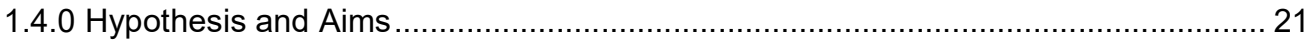

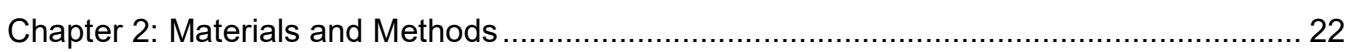

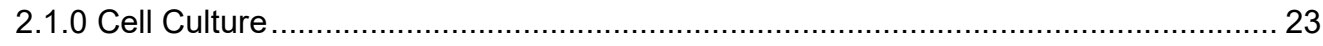

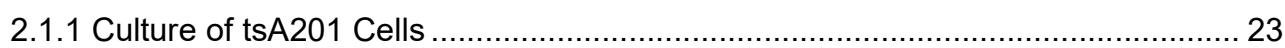

2.1.2 Preparation of Coverslips of Cells for LS-50B Ca ${ }^{2+}$ Flux Imaging ....................... 23

2.1.3 Transient Transfection of Coverslip-plated Cells with Lipofectamine-2000.......... 24 
2.1.4 Transient Transfection of $60 \mathrm{~mm}$ Dishes of Cells with Linear Polyethylenimine (PEI)

2.2.0 Assessment of Receptor Function by $\mathrm{Ca}^{2+}$ Flux Imaging …................................ 25

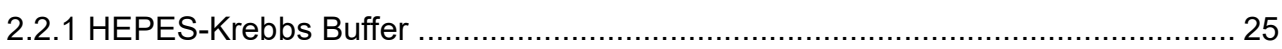

2.2.2 Cal-520 AM Fluorescent Dye Preparation ..................................................... 25

2.2.3 $\mathrm{Ca}^{2+}$ Flux Imaging of Transfected Tagged Receptor Constructs with the Perkin-

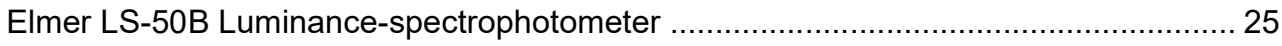

2.2.4 $\mathrm{Ca}^{2+}$ Flux Imaging with the Molecular Devices FlexStation 3 Platereader ........... 26

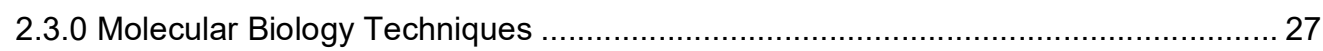

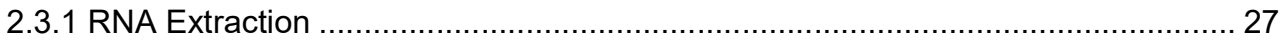

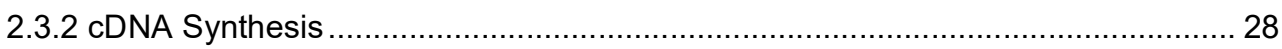

2.3.3 Reverse Transcriptase Polymerase Chain Reaction ........................................ 28

2.3.4 Agarose Gel Electrophoresis ................................................................... 32

2.3.5 Gel Band Purification and Sanger Sequencing ............................................. 33

2.3.6 Verification of the tsA201 Cell Line by Short Tandem Repeats .......................... 34

2.4.0 Co-immunoprecipitation and Western Blotting ..................................................... 34

2.4.1 Immunoprecipitation ................................................................................. 34

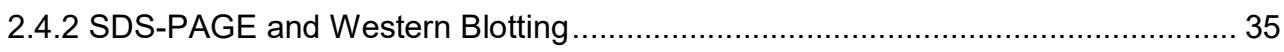

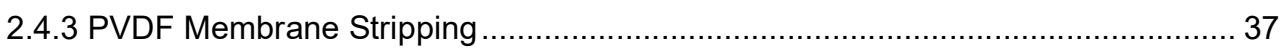

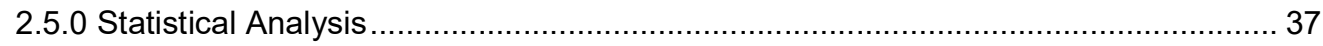

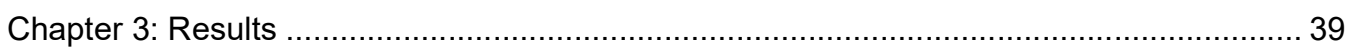

3.1.0 Cell Line Verification by Short Tandem Repeats ............................................... 40

3.2.0 Endogenous hP2Y Receptor Expression in the tsA201 Cell Line........................... 42

3.2.1 Reverse Transcriptase PCR Revealed the Expression of mRNA for Multiple hP2Y

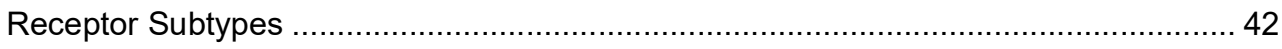

3.2.2 The RT+ Gel Bands Sequences Corresponded to the Expected Targets ............ 47

3.2.3 The RT- Gel Bands Sequences Matched with those of the Expected PCR

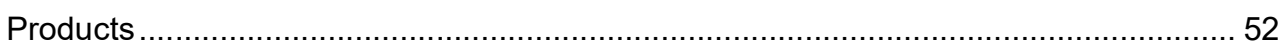

3.2.4 FlexStation $3 \mathrm{Ca}^{2+}$ Flux Imaging of Wild Type tsA201 Cells with Natural hP2Y

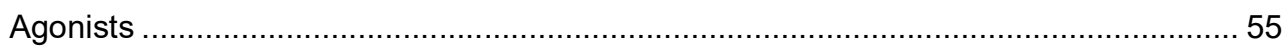

3.3.1 $\mathrm{Ca}^{2+}$ Imaging of Wild Type and Tagged hP2Y, Receptor Transfected tsA201 Cells

Demonstrated Functional Expression of the Constructs ........................................... 57

3.3.2 $\mathrm{Ca}^{2+}$ Imaging Established that the Tagged $\mathrm{hP}^{2} \mathrm{Y}_{12}$ Receptors could be Functionally

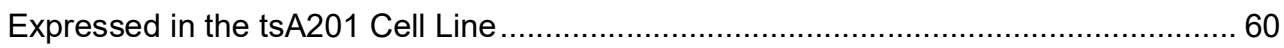

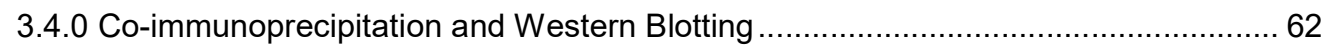

3.4.1 GFP-Immunoprecipitation and Blotting Showed that Individual FP Tagged

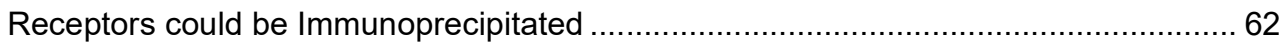


3.4.2 HA-Immunoprecipitation and Blotting Demonstrated Successful Immunoprecipitation of Individually Expressed HA Tagged Receptors...................... 62

3.4.3 HA-Immunoprecipitation of Differentially Tagged Co-expressed hP2Y 1 and hP2Y 12 Receptors and Blotting with Anti-GFP Demonstrated a High Molecular Weight Protein Complex. 65

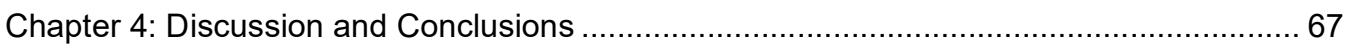

4.1.0 Endogenous hP2Y Receptor Expression in the tsA201 cell line.......................... 68

4.2.0 Tagged Receptor Construct Cellular Expression ........................................... 72

4.3.0 Interactions between the $\mathrm{hP}_{2} \mathrm{Y}_{1}$ and $\mathrm{hP} 2 \mathrm{Y}_{12}$ receptors .................................. 74

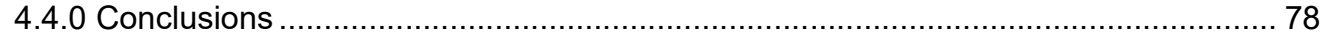

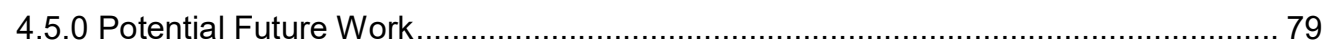

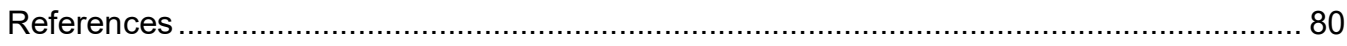




\section{List of Figures}

Figure 1: Interaction of inflammatory mediators on peripheral nociceptor surface receptors...

Figure 2: Possible stoichiometric models of $G$ protein coupling to receptors......

Figure 3: The mechanism behind the principle of resonant energy transfer methods.

Figure 4: Representative RT-PCR agarose gels of tsA201 hP2Y receptors.

Figure 5: The effect of RNAse $I_{f}$ treatment of RT- and RT+ template on $h P 2 Y_{1}$ and $\mathrm{hP} 2 \mathrm{Y}_{2}$ receptor $\mathrm{RT}$ - and $\mathrm{RT}+$ staining intensity.....

Figure 6: $\quad \mathrm{RT}-\mathrm{PCR}$ of $\mathrm{hP} 2 \mathrm{Y}_{11}$ and $\mathrm{hP} 2 \mathrm{Y}_{13}$ receptor sequences with increased primers concentrations and plasmid template amounts, plus HepG2 cDNA positive controls.

Figure 7: Alignments of the forward and reverse reads for the Sanger sequenced RT+ bands with the expected PCR products nucleotide sequences.

Figure 8: $\quad$ Alignments of the forward and reverse reads for the Sanger sequenced RT- bands with the primers resulting PCR products sequences

Figure 9: The effects of natural $\mathrm{P} 2 \mathrm{Y}$ receptor agonists on $\mathrm{Ca}^{2+}$ flux signal in wild type tsA201 cells.

Figure 10: The effect of ADP stimulation on intracellular $\mathrm{Ca}^{2+}$ signalling in wild type tsA201 cells and when transfected with hP2Y 1 -YFP or HA-hP2Y, receptor cDNA.

Figure 11: The effect of ADP stimulation on intracellular $\mathrm{Ca}^{2+}$ after transfecting hP2Y 12 -CFP or HA-hP2Y 12 receptor cDNA into the tsA201 cell line.....

Figure 12: Immunoprecipitation of singular FP tagged and HA tagged $\mathrm{hP}_{2} \mathrm{Y}_{1}$ and hP2Y 12 receptors.

Figure 13: $\mathrm{HA}$ co-IP of co-expressed tagged $\mathrm{hP}_{2} \mathrm{Y}_{1}$ and $\mathrm{hP}_{2} \mathrm{Y}_{12}$ receptors in tsA201 cells.

Figure 14: Potential hP2Y receptor mediated signalling pathways and heterodimers in the ts $\mathrm{A} 201$ cell line. 


\section{List of Tables}

Table 1: $\quad$ Properties of human P2Y receptors.................................... 4

Table 2: $\quad$ Ligand binding affinities of the $\delta-\kappa$ opioid dimer and its constituent

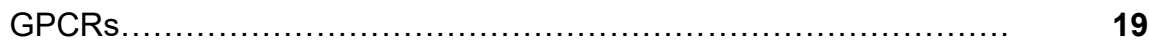

Table 3: $\quad$ Primer sequences used for the RT-PCR ............................ 29

Table 4: $\quad$ Sequences amplified by the RT-PCR primers........................ $\quad 30$

Table 5: $\quad$ RT-PCR hP2Y receptor positive control templates.................... 32

Table 6: $\quad$ Primary antibodies used for Western Blotting........................... $\quad 36$

Table 7: $\quad$ The received and the reference European Collection of Authenticated

Cell Cultures Short Tandem Repeats profiles for the tsA201

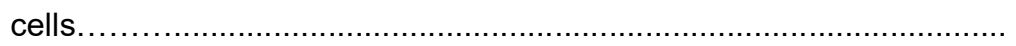




\section{List of Abbreviations}

\begin{tabular}{|c|c|}
\hline $\mathrm{AC}$ & Adenylyl cyclase \\
\hline ADP & Adenosine diphosphate \\
\hline ANOVA & Analysis of variance \\
\hline APS & Ammonium persulfate \\
\hline AR & Adrenoreceptor \\
\hline ATP & Adenosine triphosphate \\
\hline BLAST & Basic Local Alignment Search Tool \\
\hline BRET & Bioluminescent resonant energy transfer \\
\hline BSA & Bovine serum albumin \\
\hline cAMP & Cyclic adenosine monophosphate \\
\hline cDNA & Complementary deoxyribonucleic acid \\
\hline CFA & Complete Freund's adjuvant \\
\hline CFP & Cyan fluorescent protein \\
\hline CNS & Central nervous system \\
\hline Co-IP & Co-immunoprecipitation \\
\hline DMEM & Dulbeco's Modified Eagles medium \\
\hline DNA & Deoxyribonucleic acid \\
\hline DRG & Dorsal root ganglia \\
\hline DTT & Dithiothreitol \\
\hline EBI & European Bioinformatics Institute \\
\hline ECACC & European Collection of Authenticated Cell Cultures \\
\hline ECL & Enhanced chemiluminescence \\
\hline ESSFT & Extra sum of squares $\mathrm{F}$ Test \\
\hline FIIP & Formalin induced inflammatory pain \\
\hline FP & Fluorescent protein \\
\hline FRET & Försters resonant energy transfer \\
\hline GABA & Y-aminobutyric acid \\
\hline GABA & Y-aminobutyric acid \\
\hline GDP & Guanosine diphosphate \\
\hline GFP & Green fluorescent protein \\
\hline GPCR & G protein-coupled receptor \\
\hline GTP & Guanosine triphosphate \\
\hline HA & Haemagglutinin \\
\hline HEK-293 & Human embryonic kidney cells \\
\hline
\end{tabular}




\begin{tabular}{|c|c|}
\hline HRP & Horseradish peroxidase \\
\hline IASP & International Association for the Study of Pain \\
\hline IP & Immunoprecipitation \\
\hline $\mathrm{IP}_{3}$ & Inositol 1,4,5-trisphosphate \\
\hline LDS & Lithium dodecyl sulphate \\
\hline mRNA & Messenger ribonucleic acid \\
\hline MUSCLE & MUltiple Sequence Comparison by Log- Expectation \\
\hline PCR & Polymerase chain reaction \\
\hline PEI & Polyethylenimine \\
\hline $\mathrm{PI} 3-\mathrm{K}$ & Phosphatidylinositol-4,5-bisphosphate 3-kinase \\
\hline $\mathrm{PIP}_{2}$ & Phosphatidylinositol 4,5-bisphosphate \\
\hline PLC & Phospholipase C \\
\hline PTX & Pertussis toxin \\
\hline PVDF & Polyvinylidene difluoride \\
\hline RET & Resonant energy transfer \\
\hline RNA & Ribonucleic acid \\
\hline RT & Reverse transcriptase \\
\hline SDS & Sodium dodecyl sulphate \\
\hline SDS-PAGE & Sodium dodecyl sulphate polyacrylamide gel electrophoresis \\
\hline SEM & Standard error of the mean \\
\hline siRNA & Small interfering RNA \\
\hline STR & Short tandem repeats \\
\hline SV40 & Simian virus 40 \\
\hline TBE & Tris-Borate-EDTA \\
\hline TEMED & Tetramethylethylenediamine \\
\hline TRPV & Transient receptor potential cation channel subfamily $\mathrm{V}$ \\
\hline tsA201 & Temperature sensitive antigen 201 \\
\hline UDP & Uridine diphosphate \\
\hline UTP & Uridine triphosphate \\
\hline WT & Wild type \\
\hline YFP & Yellow fluorescent protein \\
\hline
\end{tabular}




\begin{abstract}
The P2Y receptor family represents a wide-ranging set of G-protein-coupled receptors that respond to purinergic ligands, and are involved in many physiological processes. From signalling assays in tsA201 cells, the Kennedy lab has previously proposed the formation of a constitutive heterodimer between co-expressed human $P 2 Y_{1}$ and $P 2 Y_{12}$ receptors; this could represent a target for the control of pain sensing neurones. Therefore, it was aimed in this project to characterise if the receptors physically interacted using coimmunoprecipitation, and also to investigate the endogenous expression of other potentially interacting hP2Y receptors in the tsA201 cell line.

In this study, tsA201 cells were determined to express mRNA for hP2Y, 2, 4, 6, 12, 14 receptors using reverse transcriptase PCR and confirmatory Sanger sequencing. Furthermore, the cells demonstrated $\mathrm{Ca}^{2+}$ responses to all of the natural $\mathrm{hP} 2 \mathrm{Y}$ receptor agonists tested, the order of potency being ADP > ATP > UTP > UDP. When co-expressing hP2 $\mathrm{Y}_{1}$ and $\mathrm{hP} 2 \mathrm{Y}_{12}$ receptors oppositely tagged with a $\mathrm{HA}$ or fluorescent protein (FP), immunoprecipitating for the HA tag and blotting for the FP showed a visible high molecular weight protein complex of $\sim 130$ to $>250 \mathrm{KDa}$ for either combination of receptors. This implied that the FP tagged receptor had co-immunoprecipitated with the other HA tagged receptor as this protein was also visible when blotting for the HA tag, signifying the presence of both tagged receptors in the complex.
\end{abstract}

These results were overall suggestive of functional hP2 $\mathrm{Y}_{1,2,12}$ receptor expression in the tsA201 cell line, and possibly also hP2Y 4, 6, 14 receptors. The high molecular weight protein complex detected could represent a constitutive $\mathrm{hP}_{2} \mathrm{Y}_{1}-\mathrm{hP} 2 \mathrm{Y}_{12}$ receptor heterodimer as proposed. Whilst it was not possible to specifically either confirm or refute the physical formation of the heterodimer with the data acquired, it was potentially supportive, and furthermore suggested other future paths of investigation. 
Chapter 1: Introduction 
Over $20 \%$ of the population in Europe have been reported to suffer from chronic pain (van Hecke et al., 2013). Unfortunately, current treatments are typically of poor efficacy and are associated with side effects, mainly due to an inadequate understanding of the underlying mechanisms; this highlights the need for research into fresh methods by which pain may be managed (Labianca et al., 2012; van Hecke et al., 2013). In recent years the Kennedy lab group at the University of Strathclyde has been characterising a potential novel target for modulating pain sensing neurones activity: in 2010 it was postulated that $\mathrm{P}^{2} \mathrm{Y}_{1}$ and $\mathrm{P} 2 \mathrm{Y}_{12}$ purinergic receptors may form a $G$ protein-coupled receptor (GPCR) dimer complex (Shrestha et al., 2010). This followed observations in temperature sensitive antigen 201 (tsA201) cells, which suggested that when recombinant receptors were transiently coexpressed and targeted by selective ligands they were able to inhibit neuronal currents in coexpressed two pore potassium channels with novel pharmacological effects; these channels have a well-defined role in pain sensing. Later $\mathrm{Ca}^{2+}$ signalling assays conducted in the same cell line corresponded with the electrophysiology data. It is therefore in this project intended to biochemically characterise the mechanisms by which these two receptors interact, and investigate other potentially interacting factors which may have been responsible for the signalling effects observed.

In this introduction the following areas will be covered: firstly, P2 purinergic receptor signalling with be examined, with the focus being on $\mathrm{P} 2 \mathrm{Y}$ receptors. Subsequently, the roles of $\mathrm{P} 2 \mathrm{Y}$, and briefly $\mathrm{P} 2 \mathrm{X}$, receptors in pain will be covered; additional contextual information on the neurobiology and pathophysiology of pain will also be presented. The concept of GPCR dimerisation will subsequently be reviewed, including research methods, functional consequences and known/proposed P2Y receptor dimers. Lastly the aims of this project will be defined.

\subsubsection{P2 Purinergic Receptor Signalling}

Although traditionally considered only as a product of intracellular energy transfer in the Krebs cycle and as source of a phosphate group for kinases, in the past 40 years it has since been recognised that adenosine triphosphate (ATP) and other purine molecules such as adenosine form part of a wide ranging extracellular signalling system. Initially identified as an inhibitory neurotransmitter from non-adrenergic, non-cholinergic nerves in the gut, later experiments revealed that ATP was a co-transmitter in many neurones, which was highly controversial at the time as it violated the so called "Dale's principle" of each neurone only releasing a single neurotransmitter (Burnstock, 2009; Burnstock, 2013b). With further 
research it was recognised that purinergic signalling receptors could be separated into two families based on their agonist selectivity, with P1 receptors (also termed as adenosine receptors) being selective to adenosine, and P2 receptors to ATP and adenosine diphosphate (ADP). $\mathrm{P} 2$ receptors were later split into $\mathrm{P} 2 \mathrm{X}$ and $\mathrm{P} 2 \mathrm{Y}$ receptors based on their pharmacology (Burnstock and Kennedy, 1985), and starting in the early 1990's the receptors began to be cloned, confirming the differences between the two branches (Abbracchio and Burnstock, 1994) and leading to the discovery of many additional subtypes in each (reviewed in Weisman et al., 2006). Various drugs targeting aspects of purinergic signalling are now in clinical use, and more continue to be developed.

\subsubsection{P2X Receptors}

P2X receptors represent a diverse family of ionotropic receptors widely expressed throughout various systems of the body. Seven subunits have been presently characterised, with all responding strongly to ATP, but not ADP, uridine-triphosphate (UTP), uridinediphosphate (UDP) or UDP-glucose. P2X subunits can form homomeric or heteromeric receptors (Khakh et al., 2001; Kennedy et al., 2013) and have been associated with a wide variety of roles, including amongst others cardiovascular disease (Kennedy et al., 2013), cancer, kidney disease and osteoporosis (Burnstock, 2013). They have additionally been identified as having important roles in pain, as briefly surmised later on in section 1.2.5.

\subsubsection{P2Y Receptors}

P2Y receptors represent a family of $G$ protein-coupled receptors (GPCRs) that respond preferentially to ATP, ADP, UTP, UDP or UDP-glucose depending on the receptor subtype. P2Y receptors follow the standard GPCR structure of 7 transmembrane domains and belong to the Class A "rhodopsin like" family of GPCRs, which is the largest class (Abbracchio et al., 2006). These bind ligands on the transmembrane helices or extracellular loops, and represent the target of purines, many neuropeptides and most amine neurotransmitters. This contrasts with the smaller Class B ("glucagon/secretin") and Class C ("metabotropic glutamate") families of GPCRs, which bind ligands on their extracellular tails and are respectively receptors for peptide hormones and ligands such glutamate (Rang et al., 2011).

Currently eight P2Y subtypes have been characterised in humans (surmised in table 1), coupled to heterotrimeric $G$ proteins. $P 2 Y_{1}, P 2 Y_{2}, P 2 Y_{4}, P 2 Y_{6}$ and $P 2 Y_{11}$ receptors mainly couple to $G_{q / 11}$ a subunits, whilst $P 2 Y_{12}, P 2 Y_{13}$ and $P 2 Y_{14}$ receptors couple to $G_{i / 0}$; the $P 2 Y_{11}$ 
receptor additionally couples to $\mathrm{G}_{\mathrm{s}}$ (Abbracchio et al., 2006). Under certain conditions the receptors may also couple with other a subunits: the $\mathrm{P}_{2} \mathrm{Y}_{13}$ receptor for instance will also couple to $\mathrm{G}_{\mathrm{s}}$ when stimulated by high concentrations of ADP (Marteau et al., 2003). The sequence gaps in nomenclature represent receptors which were initially classified as P2Y receptors when first cloned, but are now classified as other receptor types.

Table 1: Properties of human P2Y receptors

\begin{tabular}{|c|c|c|}
\hline Receptor & $\begin{array}{l}\text { Natural } \\
\text { Agonist }\end{array}$ & $\begin{array}{l}\text { G protein - Main } \\
\text { Effector(s) }\end{array}$ \\
\hline $\mathrm{P}_{2 Y_{1}}$ & ADP & $\begin{array}{l}\mathrm{G}_{\mathrm{q}}-\mathrm{PLC} \beta, \text { Rac, Rho } \\
\text { activation }\end{array}$ \\
\hline $\mathrm{P}_{2} \mathrm{Y}_{2}$ & ATP/UTP & $\begin{array}{l}\mathrm{G}_{\mathrm{q}}-\mathrm{PLC} \beta \text { activation } \\
\mathrm{G}_{\mathrm{o}}-\mathrm{PLC} \beta, \text { Rac activation } \\
\mathrm{G}_{12}-\text { Rho activation }\end{array}$ \\
\hline $\mathrm{P}_{2 Y_{4}}$ & UTP & $\begin{array}{l}\mathrm{G}_{\mathrm{q}}-\mathrm{PLC} \beta \text { activation } \\
\mathrm{G}_{\mathrm{o}}-\mathrm{PLC} \beta \text { activation }\end{array}$ \\
\hline $\mathrm{P}_{2 Y_{6}}$ & UDP & $\begin{array}{l}\mathrm{G}_{\mathrm{q}}-\mathrm{PLC} \beta \text { activation } \\
\mathrm{G}_{12 / 13}-\text { Rho activation }\end{array}$ \\
\hline $\mathrm{P}_{2 Y_{11}}$ & ATP & $\begin{array}{l}\mathrm{G}_{\mathrm{q}}-\mathrm{PLC} \beta \text { activation } \\
\mathrm{G}_{\mathrm{s}}-\mathrm{AC} \text { activation }\end{array}$ \\
\hline $\mathrm{P}_{2 \mathrm{Y}_{12}}$ & ADP & $\begin{array}{l}\mathrm{G}_{\mathrm{i} / \mathrm{o}}-\mathrm{AC} \text { inhibition } \\
\mathrm{PLC} \beta, \text { RhoA activation }\end{array}$ \\
\hline $\mathrm{P}_{2 Y_{13}}$ & ADP & $\begin{array}{l}\mathrm{G}_{\mathrm{i} / \mathrm{o}}-\mathrm{AC} \text { inhibition } \\
\mathrm{PLC} \beta, \text { RhoA activation }\end{array}$ \\
\hline $\mathrm{P}_{2 Y_{14}}$ & $\begin{array}{l}\text { UDP/UDP- } \\
\text { glucose }\end{array}$ & $\begin{array}{l}\mathrm{G}_{\mathrm{i} / \mathrm{o}}-\mathrm{AC} \text { inhibition } \\
\mathrm{PLC} \beta \text { activation }\end{array}$ \\
\hline
\end{tabular}

Summary of the natural agonists and main $\mathrm{G}$ protein

effects in human $\mathrm{P} 2 \mathrm{Y}$ receptors (Adapted from Erb and Weisman, 2012). 
G Protein Cycle and Targets:

Binding of agonists to the receptor initiates the $G$ protein cycle. On the a subunit the exchange of Guanosine diphosphate (GDP) for intracellular guanosine triphosphate (GTP) is promoted, with the $\alpha$ subunit then disassociating from the $\beta y$ complex and interacting with its target protein. GTPase activity on the a subunit increases following target interaction, hydrolysing the GTP to GDP; the $\alpha$ subunit then re-joins with the $\beta y$ complex and the cycle is ready to repeat (Rang et al., 2011). With $G_{q / 11}$ coupled $\alpha$ subunits phospholipase $C-\beta$ (PLC $\beta$ ) is activated, cleaving plasma membrane phosphatidylinositol 4,5-bisphosphate $\left(\mathrm{PIP}_{2}\right)$ to inositol 1,4,5-trisphosphate $\left(\mathrm{IP}_{3}\right)$; intracellular $\mathrm{Ca}^{2+}$ release is then triggered following the action of $\mathrm{IP}_{3}$ on endoplasmic reticulum $\mathrm{IP}_{3}$ receptors. $\mathrm{PIP}_{2}$ cleavage additionally forms diacylglycerol, which consequently activates protein kinase $C$. Subunits coupled to $G_{i / o}$ and $\mathrm{G}_{\mathrm{s}}$ however are respectively associated with the inhibition and stimulation of adenylyl cyclase (AC) activity, leading to a corresponding decrease/increase in cyclic adenosine monophosphate (cAMP) formation and hence protein kinase A activity. The released $\beta Y$ complex can also modulate its own targets, including ion channels such as $\mathrm{N}$-type $\mathrm{Ca}^{2+}$ channels (Simon et al., 2002), and PLC $\beta$ to invoke $\mathbb{I P}_{3}$ based signalling in $G_{i / o}$ coupled receptors (Murthy and Makhlouf, 1998). Along with these typical second messenger actions, P2Y receptors are able to mediate cellular activities through other pathways (reviewed in Erb and Weisman, 2012). For example $G_{q / 11}$ subunits additionally bind to and stimulate the p63RhoGEF guanine nucleotide exchange factor, which can then act on downstream Rho targets (Lutz et al., 2005).

\subsubsection{Human $\mathrm{P}^{2} \mathrm{Y}_{1}$ and $\mathrm{P}_{2} \mathrm{Y}_{12}$ Receptor Tissue Distribution}

$\mathrm{P} 2 \mathrm{Y}$ receptors are widely expressed in the human body, with $\mathrm{P} 2 \mathrm{Y}_{12}$ receptors mainly expressed on platelets, where in concert with $\mathrm{P}_{2} \mathrm{Y}_{1}$ receptors they are involved in platelet activation and aggregation, resulting in the eventual cessation of bleeding (O'Connor et al., 2011). hP2 $Y_{12}$ receptors are also present on other tissues, including endothelial, epithelial and dendritic cells, vascular smooth muscle and leukocytes, where amongst other functions they have been identified as having roles in inflammation and vasoconstriction (Gachet, 2012; Shirashaki et al., 2013; Nylander and Schulz, 2016). Additional expression is shown on brain glial cells and on neurons (Hollopeter et al., 2000, Satoh et al., 2016), where they are proposed to have important roles in pain as described later in Section 1.2.5.

In contrast, the expression of $\mathrm{hP} 2 \mathrm{Y}_{1}$ receptors is substantially wider compared to $\mathrm{hP} 2 \mathrm{Y}_{12}$ receptors, with mRNA highly expressed in ovary, intestine, prostate, placenta and brain 
tissue, lesser expressed in heart, lung and placental tissue and negligibly expressed in kidney, liver, bone and cartilage tissue (Janssens et al., 1996; Moore et al., 2001); the expression pattern for certain tissues widely varies between studies. $\mathrm{hP}_{2} \mathrm{Y}_{1}$ receptors have been located in all regions of the brain (Moore et al., 2001) and are widely expressed on neurons (Moore et al., 2000); they have likewise been proposed to have key roles in pain as detailed later on.

This wide distribution highlights one of the potential difficulties of targeting P2Y receptors clinically, due to the likelihood of off-target effects; targeting the neuronal $\mathrm{P} 2 \mathrm{Y}_{1}$ or $\mathrm{P} 2 \mathrm{Y}_{12}$ receptors for instance for pain control purposes could also lead to abnormalities in platelet or immune cell function. Interestingly a proportion of the clinical effects of anti-thrombolytic platelet $\mathrm{P}_{2} \mathrm{Y}_{12}$ receptor antagonists may result from their additional actions on endothelial and vascular smooth muscle cells (Nylander and Schulz, 2016).

\subsubsection{Clinical P2Y Receptor Ligands in Current Use}

Despite the ubiquitous expression of P2Y receptors and the many potential drug targets, this has unfortunately so far largely not translated into clinically used drugs for the majority of subtypes; mainly this is due to the difficulties of developing sufficiently selective ligands (Jacobson et al., 2009). Currently out of the few drugs in human use, anti-thrombolytic platelet $\mathrm{P}_{2} \mathrm{Y}_{12}$ receptor targeting antagonists represent the largest class. The most common of these is the pro-drug clopidogrel (Plavix), but as this relies on efficient enzymatic conversion to its active metabolite it is less effective in some patients expressing enzyme polymorphisms, and newer directly active competitive $\mathrm{P}_{2} \mathrm{Y}_{12}$ receptor antagonists such as cangrelor (also known by its developmental name ARC-69931MX and the trade name Kengrexal) and ticagrelor (Brilinta) have since been developed (O'Connor et al., 2011). Cangrelor is highly selective for the $\mathrm{P}_{2} \mathrm{Y}_{12}$ receptor, and coupled with its potent inhibitory properties - a reported $\mathrm{pA}_{2}$ of 9.2 (Horváth et al., 2014) - it is also commonly used to test for the presence of functional $\mathrm{P} 2 \mathrm{Y}_{12}$ receptor expression (Suzuki et al., 2011).

\subsubsection{Cell Lines Used for In-vitro P2Y Receptor Studies}

Human embryonic kidney cells (HEK-293) - plus derivatives such as the Simian virus 40 (SV40) transformed tsA201 and HEK-293T lines -, and the human astrocytoma 1321N1 cell lines are some of the more commonly used lines in P2Y receptor research. The former is for its ability to transiently express recombinant receptors with high efficiency (Thomas and 
Smart, 2005), and the latter for the lack of any known endogenous P2Y receptor expression (Parr et al., 1994; Suzuki et al., 2011). However, despite the popularity of HEK-293 type cell lines for studying transfected $P 2 Y$ receptors, there have been few studies looking at the overall endogenous mRNA expression of the P2Y or other purinergic receptors; even fewer have studied functional expression. This is particularly important considering that HEK-293 cells are known to endogenously express P2Y receptor subtypes (Choi et al., 2008; Suzuki et al.,2011), and it is correspondingly difficult to characterise if any observed signalling or biochemical effects were induced or modulated through the endogenous receptors presence; this has previously been responsible for misleading and unclear data (Abbracchio et al., 2005). 1321N1 cells are therefore more appropriate for P2Y research due to their lack of endogenous expression, but their use is limited by the cells being much more difficult to efficiently transiently transfect (Marucci et al., 2011) compared to HEK-293 cell lines.

\subsubsection{The Role of the Purinergic System in Pain}

The role of the purinergic system in pain was first described when it was noted that ATP invoked a painful response in blister tests (Collier et al., 1966). P2Y receptors have been implicated in the pathogenesis and maintenance of both acute and chronic pain; the different types of pain will be discussed first to place later information in context. Whilst glial cell P2Y receptors are involved in pain, the better studied peripheral receptors will be mainly concentrated on later in this section; P2X receptors roles in pain will also be briefly discussed at the end.

\subsubsection{What is Pain?}

Pain is defined by the International Association for the Study of Pain (IASP) (2012) as "An unpleasant sensory and emotional experience associated with actual or potential tissue damage, or described in terms of such damage." It can be broadly separated into two categories, acute and chronic. Acute pain is generally defined as a response to tissue damage that provides a protective function and lasts for a short time, arbitrarily set by most sources as up to 30 days (Thienhaus and Cole, 2002); it can typically be described as being nociceptive or inflammatory. Pain which continues after this is described as chronic, and is accompanied by changes in the central nervous system (CNS); chronic pain can be a result of long term inflammatory pain or from neuropathic pain, which is of a distinct cause (Voscopoulos and Lema, 2010). 


\subsubsection{Nociceptive pain}

Nociceptive pain is defined by the IASP (2012) as "Pain that arises from actual or threatened damage to non-neural tissue and is due to the activation of nociceptors." This distinguishes from the definition of neuropathic pain, and describes pain experienced with a conventionally functioning somatosensory nervous system.

Pain transduction begins at the nociceptors, peripheral specialised neuronal fibres that respond to the presence of various noxious stimuli, including heat, mechanical pressure and chemicals (see Basbuam et al., 2009 and Dubin and Patapoutian, 2010 for reviews); these are located throughout the somatic (e.g skin, muscles) and visceral tissues to mediate pain sensing (Kruger et al., 2003). Upon stimulation, reaching their activation threshold and depolarising, nociceptors transmit an action potential along their axon to higher brain centres. There are several types of nociceptive fibres, which differ in both their conductive speed and structure: of the two types associated with pain signalling, medium diameter myelinated Aठ fibres mediate initial sharp, well localised, "fast" pain, and have a lower activation threshold. These contrast with the small diameter unmyelinated $C$ fibres which mediate dull, "slow", un-localised pain, additionally having a higher activation threshold. (Basbuam et al., 2009; Gereau and Cavallone, 2013; Steeds, 2013).

Nociceptive fibres synapse in the dorsal horn of the spinal column, and the signals are then transmitted along the "pain pathways" to the brain for processing (Gereau and Cavallone, 2013; Steeds, 2013). The ascending pain pathways transmit nociceptive signals to higher brain centres, the main two pathways being the spinothalmic and the spinoreticulothalamic tracts; the former relays the strength and site of painful stimuli, whilst the latter induces psychological effects of a painful experience (Almeida et al., 2000; Basbuam et al., 2009).

The descending pathways however are associated with the modulation of pain transmission, with the fibres utilising 5-HT and noradrenaline at synapses, and enkephalins released from spinal cord interneurones acting at pre-synaptic $\mu$-opioid receptors to inhibit neurotransmitter release from nociceptive fibres (Ossipov et al., 2010; Steeds, 2013; Gereau and Cavallone, 2013). 


\subsubsection{Inflammatory Pain: the Development of Peripheral and Central Sensitisation}

The concept of neuroplasticity - where the nervous system adapts to new conditions - is a key factor in the development of pain (Puretić and Demarin, 2012). Tissue damage induces inflammatory pain, caused by the release of inflammatory mediators and cytokines from surrounding cells, including bradykinin, prostaglandins and tumour necrosis factor- $\alpha$; these interact with voltage and ligand gated channels on chemical sensitive $C$ fibres, causing fibre stimulation and nociceptive transmission (Voscopoulos and Lema, 2010) (Figure 1). The nociceptor also induces the release of mediators such as substance $P$ for stimulation and sensitisation of itself - neurogenic inflammation (Richardson and Vasco, 2002). These factors induce peripheral sensitisation: the local nociceptive fibres become more sensitive through a lowering of the activation threshold so that normally non-painful stimuli induce pain (allodynia), and there are further increased responses to painful stimuli (hyperalgaesia). In acute pain this temporary sensitisation usefully deters further damage to tissues, and returns to normal following tissue healing (Bennet, 2000; Ringkamp et al., 2013; Cohen and Mao, 2014).

Continued inflammatory pain in conditions such as rheumatoid arthritis typically leads to a state of chronic pain where the inflammation and sensitisation no longer serve any useful protective purpose. Prolonged peripheral sensitisation induces central sensitisation, causing the CNS to be in a state of hyper-excitability and enhancing pain processing because of neuronal remodelling (Puretić and Demarin, 2012). Beyond the site of the tissue damage large diameter $A \beta$ fibres that mediate touch sensing may have their normally non-painful signals processed as pain (secondary allodynia), and changes in the descending pain pathways can inhibit anti-nociceptive modulation (secondary hyperalgaesia) (Devor, 2009; Ringkamp et al., 2013; Cohen and Mao, 2014). 


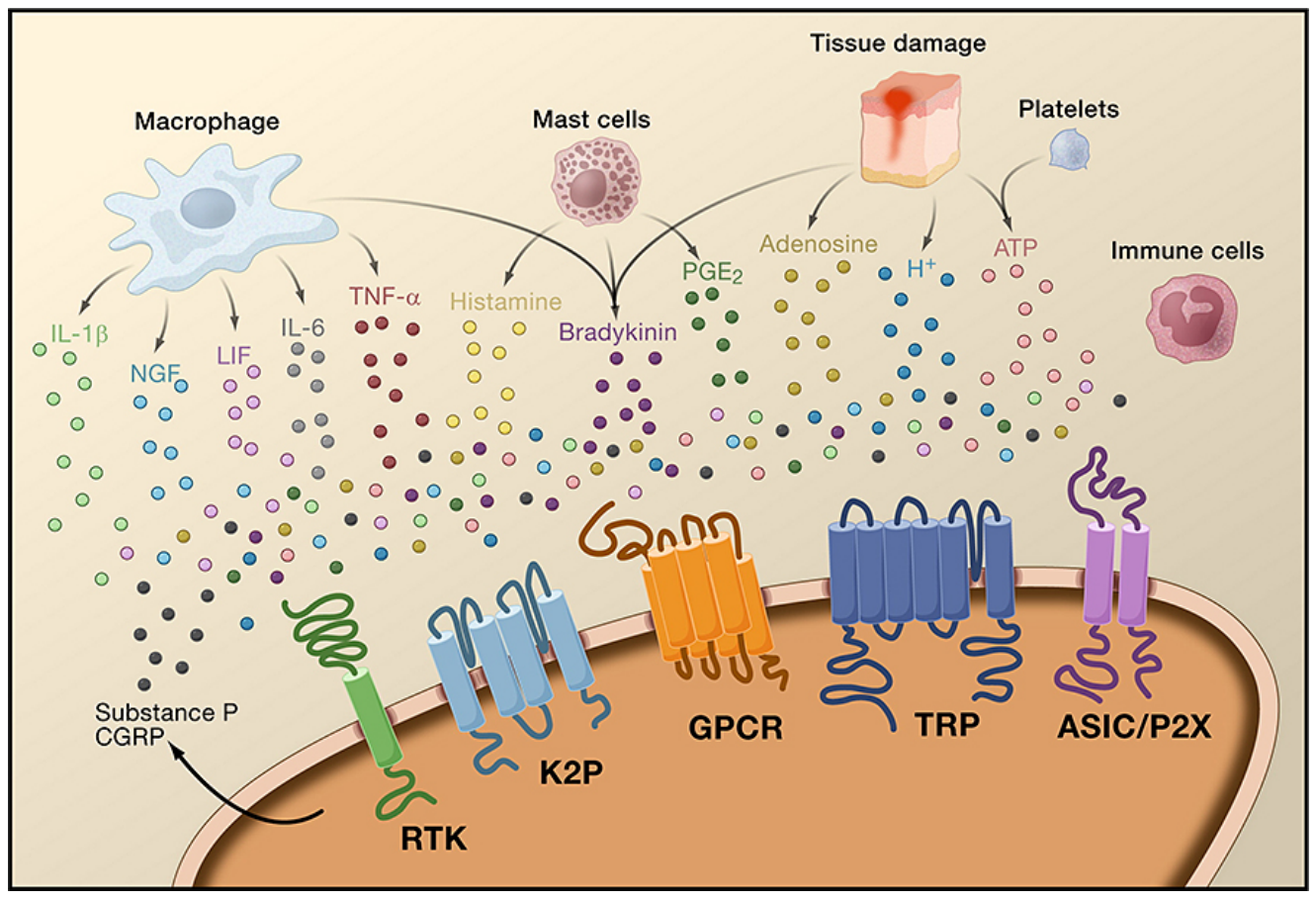

Figure 1: Interaction of inflammatory mediators on peripheral nociceptor surface receptors.

Tissue damage leads to the release of inflammatory mediators - the so called "inflammatory soup" - from surrounding cells and the nociceptor itself; these interact with surface receptors on the nociceptor, leading to nociceptive signalling and eventual peripheral sensitisation.

Reproduced from Cell, 139(2), Basbaum, Al; Bautista, DM; Scherrer, G; Julius, D., "Cellular and Molecular Mechanisms of Pain", 2009 with permission of Elsevier. 


\subsubsection{Neuropathic Pain}

Neuropathic pain is described by the IASP Taxonomy (2012) as "Pain caused by a lesion or disease of the somatosensory nervous system." As such neuropathic pain differs from nociceptive pain as it is mediated by direct damage to the neuronal fibres of the somatosensory system rather than nociceptor stimulation. Neuropathic pain is frequently described as an unremitting, "shooting", burning sensation that does not respond well to classical analgesics, and is associated with allodynia and hypersensitivity from abnormal action potential generation in the nociceptive pathways (Costigan et al., 2009; Voscopoulos and Lema, 2010; Cohen and Mao, 2014). Nerve injury induces Wallerian degeneration, resulting in production of algesic mediators and cytokines that act on the nociceptive fibre, and induce hypersensitivity in nearby uninjured fibres (Üçeyler and Sommer, 2006). Many of the mechanisms resulting in chronic neuropathic pain are similar to those in nociceptive pain: analogous neuronal remodelling mediating central sensitisation occurs, with the descending pathways losing their inhibitory functions and the changes being mediated by similar mechanisms (Costigan et al., 2009; Cohen and Mao, 2014).

\subsubsection{P2 Receptors and Pain}

Tissue injury results in the release of ATP and other purines that can act as mediators at P2 receptors expressed on sensory dorsal root ganglia (DRG), thereby influencing signalling through nociceptive fibres. With the possible exception of $\mathrm{P} 2 \mathrm{Y}_{11}$ all $\mathrm{P} 2 \mathrm{Y}$ receptor subtypes have been located on sensory DRG (Burnstock, 2013a; Magni and Ceruti, 2013), and there is extensive data on the role of $\mathrm{P} 2 \mathrm{Y}$ receptors in pain from animal models.

$\mathrm{P}_{1} \mathrm{Y}_{1}$ receptors appear to mediate heat sensitive nociception via interaction with transient receptor potential cation channel subfamily $V$ member 1 (TRPV ${ }_{1}$ ) receptors (Mallin and Moliver, 2010); low level $P 2 Y_{1}$ receptor stimulation with the selective agonist MRS2365 has been associated with an increase in thermal pain threshold, but has no effect in higher doses (Andó et al., 2010). Inhibition or knockout of P2Y $\mathrm{Y}_{1}$ inhibits the inducement of peripheral inflammatory sensitisation by complete Freund's adjuvant (CFA) (Mallin and Moliver, 2010), and additionally in formalin induced inflammatory pain (FIIP) $P 2 Y_{1}$ receptors are similarly pro-nociceptive (Barragán-Iglesias et al., 2015). $\mathrm{P}_{2} \mathrm{Y}_{2}$ and/or $\mathrm{P}_{2} \mathrm{Y}_{4}$ receptor activation with UTP raises the pain threshold in the hot plate test (Andó et al., 2010), and $\mathrm{P}_{2} \mathrm{Y}_{2}$ receptors appear to also be involved with $\mathrm{TRPV}_{1}$ and peripheral sensitisation (Moriyama et al., 2003); 
chronic inflammatory pain has been further reported to upregulate $\mathrm{P} 2 \mathrm{Y}_{2}$ receptor expression (Zhu et al., 2015).

The roles of $\mathrm{P}_{2} \mathrm{Y}_{4}$ and $\mathrm{P}_{2} \mathrm{Y}_{6}$ receptors in DRG are less clear, which is mainly due to a lack of sufficiently selective ligands. UTP or UDP administration is associated with an increase in pain threshold in the hotplate test (Andó et al., 2010), and both the receptors have been suggested to have an inhibitory role in spinal pain transmission (Okada et al., 2002). Recently though a study in rats by Barragán-Iglesias et al. (2015) using FIIP has suggested the involvement and upregulation of peripheral $\mathrm{P}_{2} \mathrm{Y}_{6}$ receptors in the development of chronic inflammatory pain; in the same study $\mathrm{P}_{2 Y_{11}}$ mRNA was located in rat DRG for the first time, and this was analogously upregulated. Activation of either $\mathrm{P}_{2} \mathrm{Y}_{6}$ or $\mathrm{P}_{2} \mathrm{Y}_{11}$ receptors before injection of formalin led to increased pain responses as quantified by flinching behaviour, and these were correspondingly reduced by the presence of antagonists prior to formalin injection.

P2Y 12, 13, 14 receptors have been suggested to have an inhibitory effect on nociceptive and inflammatory pain signalling: stimulation of any of these receptors has been associated with anti-nociceptive effects in CFA induced inflammatory pain when $\mathrm{P}_{2} \mathrm{Y}_{1}$ receptors are antagonised or knocked out (Mallin and Moliver, 2010). In contrast to this report though $\mathrm{P}_{2} \mathrm{Y}_{12}$ expression levels have also been seen to be up-regulated during hyperalgesia (Horváth et al., 2014), and selective P2Y 12 antagonists to be anti-nociceptive in all pain types in rodent models, with receptor knockout mice displaying effects similar to pharmacological inhibition (Andó et al., 2010; Horváth et al., 2014)

The effect of $\mathrm{P} 2 \mathrm{Y}$ receptors on neuropathic pain has revealed some interesting potential drug targets. The $\mathrm{P}_{2} \mathrm{Y}_{1}$ selective agonist MRS2365 has been associated with the reversal of mechanical allodynia following surgery in neuropathic pain models; UTP acting at the P2Y 2 and/or $\mathrm{P}_{2} \mathrm{Y}_{4}$ receptors was also anti-nociceptive, but to a much lesser extent (Andó et al., 2010). Selective $P 2 Y_{12}$ antagonism in particular has been associated with profound antiallodynic effects and inhibition of neuropathic pain development in several studies (TozakiSaitoh et al., 2008; Andó et al., 2010; Horváth et al., 2014). It has been demonstrated that a time dependence of peripheral and central P2Y 12 mRNA expression appears to exist, which correlates with the development of central sensitisation in rodent models for both inflammatory and neuropathic pain; this can be prevented by selective $\mathrm{P}_{2} \mathrm{Y}_{12}$ receptor antagonists or receptor knockout (Tozaki-Saitoh et al., 2008; Horváth et al., 2014). 
Amongst their many functions $\mathrm{P} 2 \mathrm{X}$ receptors have also been identified as having roles in pain: all sensory dorsal root ganglia neurones have been found to express $\mathrm{P} 2 \mathrm{X}$ receptors (Burnstock, 2013a). $P 2 X_{3}, P 2 X_{4}$ and $P 2 X_{7}$ receptors are especially implicated in the development and/or maintenance of chronic pain, which is abolished by selective receptor knockout or pharmacological inhibition (Hughes et al., 2007; Fabbretti, 2013; Tsuda et al., 2013).

Despite all this extensive research in animal models, there is however very little data regarding the role of the $\mathrm{P} 2$ receptors, or the effects of ligands targeting them, in any form of human pain (Burnstock and Sawynok, 2010). Whilst P2Y 12 receptor antagonists have been clinically used as anti-thrombolytic agents for several decades now, despite an extensive search of the literature it has only been possible to find minimal even anecdotal evidence of these drugs affecting pain perception in humans; this could be related to the doses used in clinical practice being lower than in animal model pain studies.

In a small, short duration, double blind, placebo controlled study with sickle cell anaemia patients, the platelet $\mathrm{P}_{2} \mathrm{Y}_{12}$ receptor antagonist prasugrel was associated with a lower rate and intensity of sickle cell related pain as quantified by patient diaries, but this did not reach the level of statistical significance (Wun et al., 2013). Subsequently a larger, multinational study of longer duration likewise did not find a significant effect, and the differences between the groups were not as pronounced as in the earlier study (Heeney et al., 2015). Whilst the thienopyridine class $\mathrm{P}_{2} \mathrm{Y}_{12}$ receptor antagonists clopidogrel and ticlopidine have been associated with a development or increase in joint pain and polyarthritis as a side effect in some patients (Garg et al., 2000; Dakik et al., 2002; Agrawal et al., 2013), this seems to be a class specific effect as it is typically relieved by switching affected patients to other P2 $\mathrm{Y}_{12}$ antagonists such as prasugrel (Coulter and Montandon, 2012; Agrawal et al., 2013). Because of the overall limited data available, it must be taken with caution therefore as to the extent that any animal model studies may be ultimately translatable to humans.

\subsubsection{G Protein-Coupled Receptor Dimerisation}

\subsubsection{The Concept of Dimerisation}

Traditionally GPCRs were considered to be monomeric entities that coupled with G proteins on a $1: 1$ stochiometric basis to cause physiological effects. However, whilst this model is indeed possible (Chabre and le Maire, 2005), it is now well established this simplistic view 
may not be appropriate in a number of cases, and that multiple GPCRs can interact with one another in various compartments to form dimeric complexes, which may be linked to one or several G proteins if expressed on the cell surface (Ferré et al., 2009; Kamal et al., 2011; Ferré et al., 2014) as illustrated in Figure 2. These may have different functional properties compared to their singular receptors, and have been long proposed as lucrative potential new drug targets, although this has not come to fruition yet (Bortolato et al., 2009). The alternate terms "oligomer" or "multimer" may be used in other literature, but in this thesis the term "dimer" will be used as it is seen as the smallest multimeric unit.

Dimers can be receptors both of the same type interacting together - "homodimers" - or of entirely different types, so called "heterodimers" (Ferré et al., 2009); indeed, two receptors does not seem to be the limit either, with evidence of higher order dimers - "multimers" appearing for numerous receptor types (Vischer et al, 2011). In some cases, such as most Class C GPCRs, it has been conclusively demonstrated that dimerisation is essential for normal receptor expression and function (Pin et al., 2007).

a)

Monomer

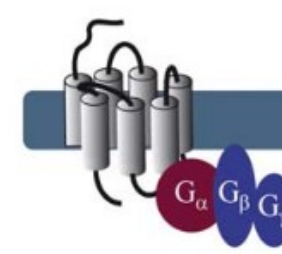

b)

Dimer

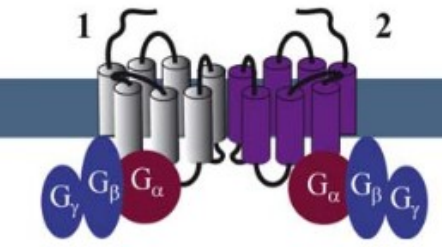

c)

Dimer

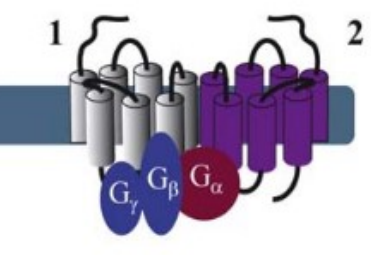

Figure 2: Possible stoichiometric models of $\mathrm{G}$ protein coupling to receptors

a) 1:1, the simplest possible model, a monomeric receptor coupled to a heterotrimeric $G$ protein b) 2:2, two $G$ proteins, each coupled to a protomer within a dimer complex c) 2:1, a single $G$ protein-coupled to both protomers of a dimer complex (Figure reproduced from Kamal et al., 2011 under an Open Access Licence).

\subsubsection{A Brief History of Dimerisation and Research Techniques}

The first indications of GPCR dimerisation came indirectly in the mid 1970's with pharmacological binding assays that appeared to show negative or positive cooperativity, suggesting the presence of multiple binding sites (Limbird and Lefkowitz, 1976; Maggi et al., 1980). Beginning in 1982 target size analysis experiments using radiation inactivation indicated that functional receptors tended to have a molecular weight twice or more the size of singular receptors measured using biochemical techniques, leading to suggestions that 
the functional receptors were formed of two or further subunits (Fraser and Venter, 1982; $\mathrm{Ng}$ et al., 2013). Using target size analysis several possible homodimers were identified, including for $\beta 2$ adrenoreceptors (AR) (Fraser and Venter, 1982), a1AR (Venter et al., 1984) and opioid receptors (McLawhon et al., 1983), but the technique was limited as it could not differentiate between receptor-receptor and other receptor-protein interactions (Rios et al., 2001).

Although this approach, and others such as trans-complementation where truncated mutated receptors of differing types displayed restored signalling and function when co-expressed (Maggio et al., 1993), provided a large pool of evidence supporting the concept of dimerisation, there was no direct proof. The development of differential epitope tagging of recombinant receptors combined with co-immunoprecipitation and Western blotting was a major step as it was able to detect direct receptor-receptor interactions. With the first application of this technique $\beta 2 A R$ homodimerisation was demonstrated by Hebert et al. (1996), providing the first direct physical evidence of dimerisation; it was shortly expanded to probing the heterodimerisation of $\delta$-к opioid receptors (Jordan and Devi, 1999) and has since become the most commonly used biochemical method (Szidonya et al., 2008). It does however have drawbacks such as that it requires a high level of receptor overexpression, which may artificially induce dimer formation (Szidonya et al., 2008); furthermore, incomplete solubilisation may cause formation of non-specific aggregates (Salim et al., 2002).

Biochemical techniques have a disadvantage in that they are unable to be used with living cells. More recently biophysical resonant energy transfer (RET) techniques such as bioluminescent RET (BRET) and Försters RET (FRET) have become popular, both for their ease of use and for their ability to quantify dimer formation in living cells ( $\mathrm{Ng}$ et al., 2013). RET (Figure 3) uses energy transfer from an excited fluorescent/luminescent "donor" molecule - for example cyan fluorescent protein [CFP] - expressed recombinantly on one receptor to an "acceptor" - in the case of CFP, typically yellow fluorescent protein (YFP) - on another receptor if in close enough proximity - approximately $50 \AA$ for BRET (Angers et al., 2000) -, producing detectable fluorescence (Goddard and Watts, 2012). The RET approach offers the some of the best resolution strategies for studying dimers (Goddard and Watts, 2012; Ng et al., 2013) and has been used to suggest the development of many different dimers. However, RET is limited as it functions on close rather than physical association, so it is important that protocols are followed and controls taken to avoid mis-interpretation (Marullo and Bouvier, 2007). Furthermore, a major additional drawback is that it can typically only be used in a tagged, recombinant overexpression system, and as so RET is usually unable to be used to detect native dimers (Persani et al., 2007). 
It has additionally become apparent that higher order "multimers" (also termed oligomers) may also form between GPCR dimers. Although potentially eluded to by early methods it wasn't until the development of modern co-immunoprecipitation and RET techniques that the concept was able to gain acceptance, but even these are unable to easily provide data on the order of a dimer. Amongst other studies, using three unique tags Park and Wells (2004) were able to co-immunoprecipitate muscarinic $M_{2}$ receptors of at least trimeric order. Some of the most compelling potential evidence for multimers has stemmed from the publication of GPCR structures using atomic force microscopy, with the rhodopsin structure appearing to consist of paracrystalline arrays of receptors (Fotiadis et al.,2004). However, the structure has been criticised on methodological grounds (Chabre and le Maire, 2005), and it has been pointed out that interpretation of atomic force microscopy images is somewhat subjective (Gurevich and Gurevich, 2008). Both the potential functional consequences and the existence of multimers in-vivo are still largely unclear.

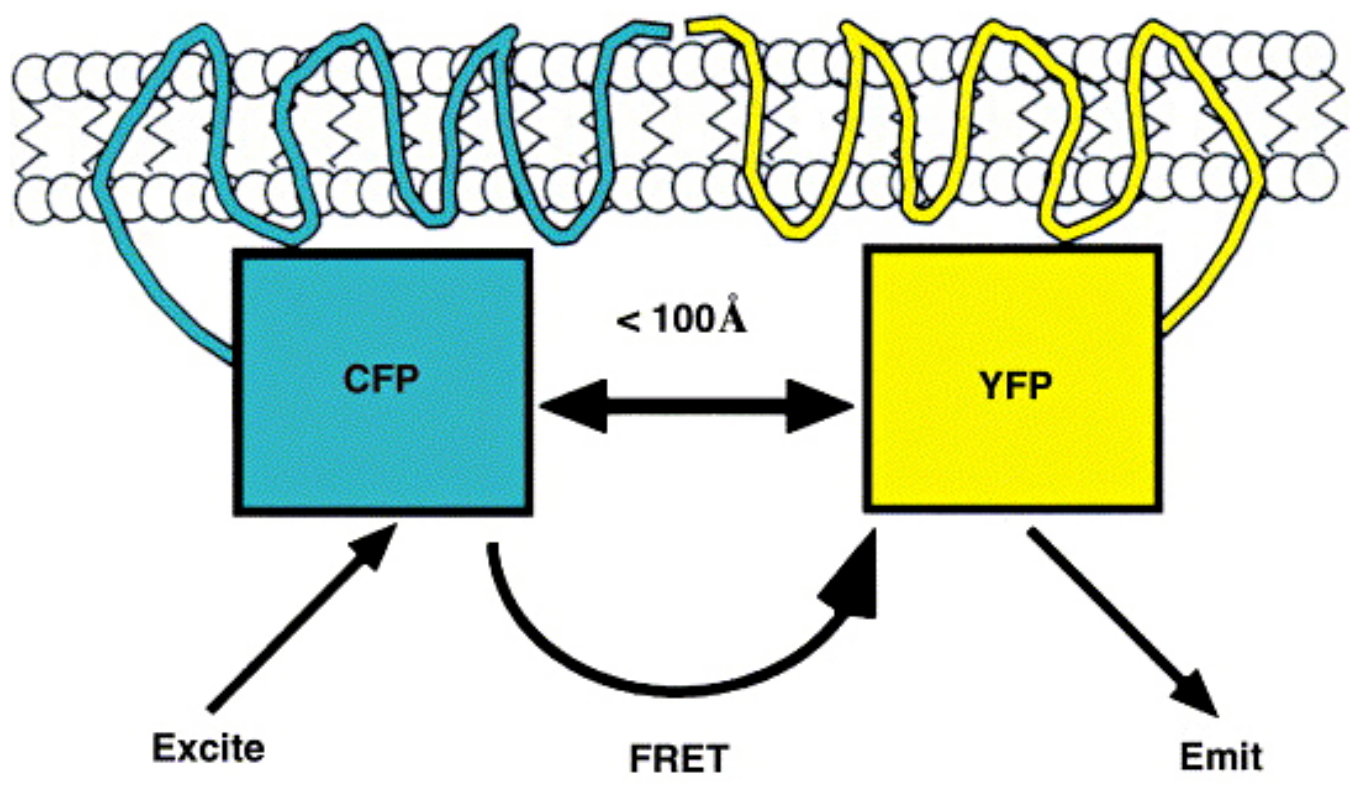

Figure 3: The mechanism behind the principle of resonant energy transfer methods

A fluorescent donor molecule - cyan fluorescent protein in this case - on one receptor is excited by a background fluorescent source, and if it is within close enough proximity then the partner acceptor molecule - yellow fluorescent protein in this case - will subsequently emit detectable fluorescence of a known wavelength from energy transfer. Although this example shows Försters resonant energy transfer (FRET), the principle is similar for other RET technologies

Figure reproduced from Methods, 27(4), Overton MC and Blumer KJ., "Use of fluorescence resonance energy transfer to analyze oligomerization of G-protein-coupled receptors expressed in yeast", 2002 with permission of Elsevier. 


\subsubsection{The Dynamic Nature of Dimerisation}

One point that has become clear is that GPCR dimerisation is typically dynamic, and as well as existing as dimers in a basal state the order of a GPCR may change in response to various factors. Using a biophysical single molecule technique for instance it has demonstrated that $\beta_{1} A R, \beta_{2} A R$, and $\gamma$-aminobutyric acid $B\left(G A B A_{B}\right)$ receptors each move between monomeric, dimeric or multimeric states based on a number of factors including agonist stimulation and receptor density (Calebiro et al., 2012). Additionally, a large proportion of $\mathrm{hP} 2 \mathrm{Y}_{1}$ receptors transfected into the HEK-293 cell line have been seen to exist as homodimers, but upon agonist stimulation the proportion of dimers to monomers further increases (Choi et al., 2008)

\subsubsection{Functional Examples of GPCR dimers}

Although by now it is commonly accepted that GPCRs form dimers, perhaps the most important information to date has come from cases where it has been found to affect GPCR function; some prominent examples will now be discussed.

\section{Receptor expression:}

It has been found that for cellular expression it is necessary for some GPCRs to first dimerise. The most well-known example is likely the $G_{A B A}$ receptor, which after being initially cloned was found to have substantially lower affinity for agonists than native receptors (Kaupmann et al., 1997), as it was unable to be expressed on the cell surface (Couve et al., 1998). Shortly another $G_{A B} A_{B}$ form was identified, $G A B A_{B(2)}$, and it was found to be vital for this to be co-expressed with the original cloned receptor $\left(G_{\left.A B A_{B(1)}\right)}\right)$ in order for a functional $G A B A_{B}$ receptor to be expressed, leading to the conclusion that $G A B A_{B}$ receptors are inherently heterodimers of these two subunits (Jones et al., 1998; Kaupmann et al., 1998; White et al., 1998). It has since been identified that in the heterodimer complex the $G_{A B A_{B(1)}}$ subunit expresses the orthosteric ligand binding site, whilst the $G A B A_{B(2)}$ subunit couples with the $G$ protein to mediate the signalling effects (Margeta-Mitrovic et al., 2001; Bettler et al., 2004). However there is evidence which challenges this essential heterodimerisation theory, as there is partial overlap or separation of function in certain cases: $\mathrm{GABA}_{\mathrm{B}(2)}$ has appeared to independently couple to $A C$ despite being lacking a ligand binding site (Martin et al., 1999), and $\mathrm{GABA}_{\mathrm{B}(1)}$ alone has been reported to inhibit TRPV 1 
sensitisation (Hanack et al., 2015). This may result from alternative isoforms of $\operatorname{GABA}_{B(1)}$ (Calver et al. 2000; Jacobson et al., 2006 Pinard et al., 2010).

Since this seminal discovery of $\mathrm{GABA}_{B}$ 's essential heterodimerisation it has become apparent that most Class C GPCRs function likewise, but some have been found to not be heteromers and may act through "cross talk" mechanisms that do not involve physical association (Prezeau et al., 2010).

\section{Pharmacology:}

For some dimer pairs it has been established that the fundamental pharmacology can alter upon dimerising; there have long been indirect indications of individual receptor types seeming to alter their binding affinity for specific ligands when other receptor types were coexpressed (Maggi et al., 1980). The opioid receptor family is probably the best characterised example in this area, with the first direct indications coming from Jordan and Devi (1999). Potential heterodimerisation between transfected $\delta$-opioid ( $\delta$-OR) and $\kappa$-opioid ( $\kappa-O R$ ) receptors was established using co-immunoprecipitation, and furthermore as summarised in table $2 \delta$ - $\kappa$ opioid dimers appeared to show practically no binding affinity for $\kappa$ or $\delta$ selective agonists, but incubation with specific ligands to one receptor type appeared to synergistically increase the binding affinity to agonists for the other receptor; $\delta$-к opioid dimerisation has subsequently been supported by later BRET analysis (Ramsay et al., 2002). Potential $\mu-\delta$ opioid dimers have also been found using co-immunopreceipitation (George et al., 2000; Gomes et al., 2000) and BRET (Gomes et al., 2004), and are reported to have similar ligand binding characteristics to $\delta$-к opioid dimers (Gomes et al., 2004; Gomes et al., 2011).

Although Jordan and Devi (1999) were unable to co-immunoprecipitate $\mu$-к opioid dimers, later studies have indicated heterodimers through both co-immunoprecipitation and BRET (Wang et al., 2005; Chakrabarti et al., 2010). $\mu$-к opioid dimers in contrast seem to retain their affinity for $\kappa$ selective agonists, whilst maintaining the reduced $\mu$-receptor binding affinity; binding of $\kappa$ selective agonists seems to increase $\mu$-receptor binding affinity, but no opposite effect has been observed (Wang et al., 2005) 
Table 2: Ligand binding affinities of the $\delta$ - $\kappa$ opioid dimer and its constituent GPCRs.

\begin{tabular}{|c|c|c|c|}
\hline Ligand & $\mathbf{K i}(\mathrm{nM})$ & & \\
\hline Agonists & $\kappa-O R$ & D-OR & $\kappa-O R / \delta-O R$ \\
\hline U69593 (к-OR selective) & $14.4 \pm 0.2$ & $>1000$ & $>1000$ \\
\hline DPDPE ( $\delta$-OR selective) & $>1000$ & $21.8 \pm 2.1$ & $>1000$ \\
\hline \multicolumn{4}{|l|}{ Antagonists } \\
\hline $\begin{array}{l}\text { Norbinaltorphimine (mainly } \\
\kappa-O R \text { selective) }\end{array}$ & $4.9 \pm 0.3$ & $31.8 \pm 1.2$ & $126 \pm 9.6$ \\
\hline TIPP ( $\delta$-OR selective) & $>1000$ & $0.28 \pm 0.6$ & $>1000$ \\
\hline \multicolumn{4}{|l|}{ Combinations of ligands } \\
\hline U69593 (+ $10 \mu \mathrm{M}$ DPDPE) & $14.4 \pm 0.4$ & - & $9.2 \pm 1.4$ \\
\hline DPDPE (+ $10 \mu \mathrm{M}$ U69593) & - & $24.8 \pm 1.6$ & $20.0 \pm 1.3$ \\
\hline
\end{tabular}

The effect of $\delta$ - $\kappa$ dimerisation on ligand binding affinity with a competition binding assay using the non-selective opioid receptor ${ }^{3}[\mathrm{H}]$-diprenorphine. \pm standard error of the mean. Adapted from Jordan and Devi (1999).

\section{Signalling:}

It has become apparent that dimerisation will sometimes alter the signal transduction mechanisms used by the constituent GPCRs. A prominent example is the dopamine $D_{1}-D_{2}$ heterodimer; $D_{1}$ and $D_{2}$ receptors are known to couple to $G_{s}$ and $G_{i / o}$ subunits respectively, and act through the second messenger AC system (Beaulieu and Gainetdinov, 2011). However, over the years reports were published where it appeared that a $D_{1}$ like receptor was able to stimulate intra-cellular $\mathrm{Ca}^{2+}$ release in striatal brain tissue (Undie et al., 1994; Wang et al., 1995; Pacheto and Jope, 1997; Jin et al, 2003; Tang and Bezprozvanny, 2004). This effect was insensitive to pertussis toxin (PTX) - a potent inhibitor of AC - (Wang et al., 1995 ) and was blocked by a $G_{q / 11}$ monoclonal antibody (Pacheto and Jope, 1997), which suggested $\mathrm{G}_{\mathrm{q} / 11}$ coupling. This release of intra-cellular $\mathrm{Ca}^{2+}$ was later found to only occur when $D_{1}$ and $D_{2}$ receptors were co-expressed together, and this could be blocked by PLC inhibitors, suggesting the possible formation of a $G_{q / 11}$ coupled dimer (Lee et al., 2004; Rashid et al, 2007). Co-immunoprecipitation (Lee et al., 2004) and RET (So et al., 2005) studies indicated formation of a $D_{1}-D_{2}$ heterodimer, which was later located in native striatal tissue (Lee et al., 2004; Rashid et al, 2007). 


\subsubsection{Criticism of Dimerisation}

Whilst the concept of dimerisation is now well established, and numerous studies on an array of GPCRs appear to support the notion, it has been questioned as to how much of this "evidence" can be seen as biologically relevant (Chabre and le Maire, 2005; Pin et al., 2007; Ferré et al., 2009; Teitler and Klein, 2012; Ferré et al., 2014). As previously stated all of the methods used to investigate in-vitro have their inherent advantages and disadvantages, but this has created a pool of disjointed and contradictory data which can have multiple interpretations (Gurevich and Gurevich, 2008; Palczewski, 2010; Vischer et al, 2011). The evidence for class A and B GPCRs forming dimers is much less clear cut than with class C GPCRs (Ferré et al., 2014), especially as only a small proportion of reported dimers have been characterised in native cells, even fewer in-vivo, and only a select number meet the guidelines reached by the International Union of Basic and Clinical Pharmacology (Pin et al., 2007). GPCR dimerisation remains a controversial area, and a detailed assessment of the evidence is beyond the scope of this review.

\subsubsection{P2Y Receptor Dimers}

It has been reported that P2Y receptors appear to be able to form both homodimers and heterodimers. As previously detailed in section 1.3.3 $\mathrm{P}_{2} \mathrm{Y}_{1}$ receptors appear to constitutively

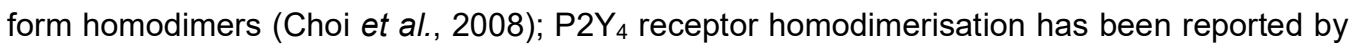
d'Ambrosi et al. (2006) using co-immunoprecipitation of tagged transfected receptors; later work by the same group has found that native $\mathrm{P}_{2} \mathrm{Y}_{4}$ receptors appear to exist predominantly as homodimers and homo-multimers (d'Ambrosi et al., 2007) using blue native and sodium dodecyl sulphate polyacrylamide gel electrophoresis (SDS-PAGE). In the same study it was also found that not only does $\mathrm{P}_{2} \mathrm{Y}_{6}$ seem also able to form homodimers, but that it can additionally form heterodimers with $\mathrm{P}_{2} \mathrm{Y}_{4}$ receptors in transfected and endogenous cells; whilst the native $\mathrm{P}_{2} \mathrm{Y}_{4}$ receptors preferentially consisted as homodimers and homooligomers, $\mathrm{P} 2 \mathrm{Y}_{6}$ receptors in contrast formed homodimers in response to agonist stimulation. $\mathrm{P}_{2} \mathrm{Y}_{12}$ receptors have been observed as predominantly existing as homo-oligomers; interestingly the active metabolite of the antithrombotic agent clopidogrel appears to interfere in this homodimerisation, which may represent part of its mechanism of action (Savi et al., 2006). The $P 2 Y_{12}$ receptors crystal structure when in complex with an antagonist molecule has further suggested dimeric interactions between $\mathrm{P}_{2} \mathrm{Y}_{12}$ receptors via cholesterol molecules (Zhang et al., 2015). 
Both $P 2 Y_{1}$ and $P 2 Y_{2}$ receptors have been reported to form heterodimers with adenosine $A_{1}$ receptors. The $\mathrm{P}_{2} \mathrm{Y}_{1}-\mathrm{A}_{1}$ dimer has complex effects on the pharmacology and signalling properties, including activation of both $G_{i}$ and $G_{q}$ subunits, and a substantial reduction in binding affinity for $A_{1}$ ligands, but a comparative increase for $\mathrm{P}_{2} \mathrm{Y}_{1}$ ligands (Yoshioka et al., 2001). $P 2 Y_{2}-A_{1}$ receptor dimerisation on the other hand didn't appear to have any effect on ligand binding affinity, but simultaneous stimulation with agonists for both GPCRs enhanced $\mathrm{G}_{\mathrm{q}}$ signalling and inhibited $\mathrm{G}_{\mathrm{i}}$ based signalling (Suzuki et al., 2006).

$\mathrm{P}_{2} \mathrm{Y}_{1}$ and $\mathrm{P} 2 \mathrm{Y}_{11}$ receptors have been reported to form heterodimers using both coimmunoprecipitation and FRET. Interestingly this dimerisation not only appeared to enable the agonist induced internalisation of the $\mathrm{P}_{2} \mathrm{Y}_{11}$ receptor, something that its monomer is not capable of, but it was also able to alter the ligand selectivity of the receptor (Ecke et al., 2008). Work in the Kennedy lab group has researched possible dimerisation between $P 2 Y_{1}$ and $\mathrm{P} 2 \mathrm{Y}_{12}$ receptors in tsA201 cells. The two co-expressed receptors appeared to interact to modulate the signalling activity of co-transfected two pore potassium channels, showing the pharmacological profile of both receptors, but the signalling properties of $\mathrm{P}_{2} \mathrm{Y}_{1}$ (Shrestha et al., 2010), and the formation of a heterodimer being proposed as the mechanism. Later $\mathrm{Ca}^{2+}$ signalling based pharmacological assays were able to reproduce this data (Naughton et al., 2014).

\subsubsection{Hypothesis and Aims}

It is hypothesised that $P 2 Y_{1}$ and $P 2 Y_{12}$ receptors will form a GPCR dimer complex upon coexpression in the tsA201 cell line, which will be detectable by co-immunoprecipitation. Therefore, it is aimed in this project to characterise the mechanisms by which the two receptors interact, in addition to evaluating other potentially interacting factors which may have had a role in influencing the signalling data seen previously.

It is firstly intended to characterise the expression of endogenous human P2Y receptor subtypes in the tsA201 cell line by reverse transcriptase polymerase chain reaction and functional assays. Recombinant haemagglutinin (HA) or fluorescent protein (FP) tagged human $\mathrm{P}_{2} \mathrm{Y}_{1}$ and $\mathrm{P} 2 \mathrm{Y}_{12}$ receptors will next be transfected into the tsA201 cell line, and $\mathrm{Ca}^{2+}$ flux imaging utilised to verify that the tagged receptors are functionally expressed and operate similarly. Whether the proposed $\mathrm{P}_{2} \mathrm{Y}_{1}-\mathrm{P}_{2} \mathrm{Y}_{12}$ receptor dimer forms physically will then be lastly investigated, using co-immunoprecipitation with subsequent Western blotting against the receptor tags. 
Chapter 2: Materials and Methods 


\subsubsection{Cell Culture}

All cell culture was carried out under aseptic conditions in a class II biological safety hood.

\subsubsection{Culture of tsA201 Cells}

tsA201 cells (European Collection of Authenticated Cell Cultures [ECACC] 96121229) were thawed from frozen stocks and maintained at $37^{\circ} \mathrm{C}$ in a $5 \% \mathrm{CO}_{2} 95 \% \mathrm{O}_{2}$ humidified atmosphere in Dulbeco's Modified Eagles medium (DMEM) augmented with 10\% foetal bovine serum, $1 \%$ non-essential amino acids and $1 \%$ penicillin $(10000 \mathrm{U} / \mathrm{ml}) /$ streptomycin $(10000 \mathrm{U} / \mathrm{ml})$ - referred to herein as "complete" media. All media components were sourced from Thermo Fisher Scientific.

The cells were grown in Corning T25 or T75 flasks and when at $70-90 \%$ confluence were washed twice with serum-free DMEM prior to being incubated with trypsin for 5 minutes at $37^{\circ} \mathrm{C}$ to detach. The cells were then brought up to the flasks working volume with complete media to inactivate the tryspin, and subsequently split and re-plated at between 1:2 and 1:10 in a new flask. Later on in the project the initial washes were omitted and versene solution was used in place of the tryspin, with the cells being placed in the incubator for 2 minutes to detach; the versene was subsequently removed by centrifugation after addition of complete media. The remaining cells were discarded or used for other experiments detailed further on; the media was changed every 2 days and the cells were utilised between passages 11 and 37.

\subsubsection{Preparation of Coverslips of Cells for LS-50B Ca ${ }^{2+}$ Flux Imaging}

tsA201 cells from splitting were gently pipetted onto $13 \mathrm{~mm}$ diameter poly-L-lysine $(1 \mathrm{mg} / \mathrm{ml})$ coated glass coverslips in a $35 \mathrm{~mm}$ sterile petri dish at a dilution suitable for a $\geq 80 \%$ confluent monolayer to have formed in 24 hours. The dishes were then placed in the incubator for two hours for the cells to adhere to the coverslips, and for wild type only cells the petri dish was filled with complete media 2 hours later for use in $24-48$ hours. 


\subsubsection{Transient Transfection of Coverslip-plated Cells with Lipofectamine-2000}

For experiments where $\mathrm{Ca}^{2+}$ flux was recorded, Lipofectamine-2000 (Thermo Fisher Scientific) was used to transiently insert cDNA sequences expressed in plasmids (HA$h P 2 Y_{1}, H A-h P 2 Y_{12}, h P 2 Y_{1}-Y F P$ and $h P 2 Y_{12}-C F P$ receptor containing plasmids were used) into the coverslip-plated cells. After allowing the cells 2 hours to adhere to the coverslips, the dishes had $2 \mathrm{ml}$ of serum-free DMEM added and were allowed to incubate for 15 minutes; 1 $\mu \mathrm{g}$ of the respective plasmid was used in a cDNA:Lipofectamine-2000 mix with a ratio of 1 $\mu \mathrm{g}: 1.5 \mu \mathrm{l}$, prepared in serum-free DMEM. This was left to incubate in the hood for 5 minutes before being slowly added to the dish of coverslips, which was gently rocked to mix; the dishes were then placed back in the incubator for 24 hours before the media (and plasmid) was aspirated off and replaced with complete media. The coverslip-plated cells were then used for $\mathrm{Ca}^{2+}$ flux imaging 24-48 hours later.

\subsubsection{Transient Transfection of $60 \mathrm{~mm}$ Dishes of Cells with Linear Polyethylenimine (PEI)}

For biochemical experiments, PEI (linear, MW-2500 from Polysciences Inc) was used for transient transfection of plasmids (containing HA-hP2Y1, HA-hP2Y12, hP2Y1-YFP or hP2Y12-CFP receptors or green fluorescent protein [GFP]) due to the prohibitive cost of using Lipofectamine-2000 for the quantity required. $60 \mathrm{~mm}$ dishes were seeded with cells on a 1:4 ratio of cells to complete media and later transfected when overall confluence was between $50 \%$ and $80 \%$. $2.5 \mu \mathrm{g}$ of each plasmid to be inserted $(2.5 \mu \mathrm{g}$ or $5.0 \mu \mathrm{g}$ total cDNA content) and $15 \mu \mathrm{g} \mathrm{PEI}$ were separately diluted in serum-free DMEM and after 5 minutes combined together by adding the PEI to the CDNA and leaving for at least 15 minutes at room temperature before adding to the dishes in serum-free DMEM drop by drop. The dishes were placed back in the incubator for 24 hours, with the media then replaced with complete media before the cells were harvested for immunoprecipitation experiments after a further 24 hours. 


\subsubsection{Assessment of Receptor Function by $\mathrm{Ca}^{2+}$ Flux Imaging}

\subsubsection{HEPES-Krebbs Buffer}

HEPES-Krebbs buffer (122 mM NaCl, $5 \mathrm{mM} \mathrm{KCl,} 10 \mathrm{mM}$ HEPES, $0.5 \mathrm{mM} \mathrm{KH}_{2} \mathrm{PO}_{4}, 0.5 \mathrm{mM}$ $\mathrm{NaH}_{2} \mathrm{PO}_{4}, 1 \mathrm{mM} \mathrm{MgCl}$, $11 \mathrm{mM}$ glucose, $1.8 \mathrm{mM} \mathrm{CaCl}$ ) was prepared immediately before each experiment and titrated to $\mathrm{pH} 7.30$ with $\mathrm{NaOH}$.

\subsubsection{Cal-520 AM Fluorescent Dye Preparation}

Cal-520 AM fluorescent dye (Abcam) was prepared from a frozen $1 \mathrm{mM}$ in DMSO stock to a final $5 \mu \mathrm{M}$ concentration in HEPES-Krebbs buffer plus 0.05\% F-127 Pluoronic acid (Thermo Fisher Scientific). The dye was added to the cells (for coverslips $1.5 \mathrm{ml}$ of solution per dish and for 96 well plates $100 \mu \mathrm{l}$ per well) and incubated at $37^{\circ} \mathrm{C}$ for 1 hour; 96 well plates were also given an additional 30 minutes of incubation at room temperature as recommended in the dyes product literature. Coverslips were washed twice with buffer prior to use whilst 96 well plates were aspirated and the dye replaced with $90 \mu \mathrm{l}$ of buffer in each well; all assays were ran at room temperature as recommended.

\subsection{3 $\mathrm{Ca}^{2+}$ Flux Imaging of Transfected Tagged Receptor Constructs with the Perkin- Elmer LS-50B Luminance-spectrophotometer}

In order to test whether the introduction of HA or FP tags interfered with normal receptor functioning and they could be functionally expressed, $\mathrm{Ca}^{2+}$ flux assays were used to determine if the receptors responded as expected to pharmacological ligands when transfected into coverslip-plated tsA201 cells. The coverslip being assayed was placed in a cuvette in the path of the LS-50B luminance/spectrophotometer (Perkin-Elmer) excitation beam and photodetector. HEPES-Krebbs buffer was continuously perfused into the cuvette at $4 \mathrm{ml} / \mathrm{min}$ by gravity and aspirated out by suction to maintain a constant flow of new buffer. Recordings were each made at a $10 \mathrm{~Hz}$ sampling frequency with $490 \pm 10 \mathrm{~nm}$ excitation and $525 \pm 10 \mathrm{~nm}$ emission settings using Perkin-Elmer FL Winlab V4.00.02 software.

After recording 30 seconds of baseline, ADP (Sigma-Aldrich) was added by changing the perfusion buffer over to a separate source containing the necessary concentration of ligand 
made up in buffer. This was allowed to perfuse until the $\mathrm{Ca}^{2+}$ response had peaked and the source was then switched back to buffer only; each recording was a total of 5 minutes long with a subsequent 5 minute washout period before the next ADP addition (10 minutes for 1 $\mu \mathrm{M}$ ADP and above). Each coverslip was initially subjected to two additions of $10 \mu \mathrm{M}$ ADP before proceeding to further experimentations, and after data capture the files were imported into GraphPad Prism 7 (GraphPad Inc), with every 20 time points averaged and response calculated by manually subtracting the baseline from the peak response.

For wild type (WT) and hP2Y 1 receptor transfected tsA201 cells ADP concentration-response curves were produced, with all responses being normalised as a percentage of that of the final $10 \mu \mathrm{M}$ ADP concentration. These were fitted with the "log(agonist) vs. response -variable slope" equation in GraphPad Prism 7 to calculate the $\log \mathrm{EC}_{50}$ - which is expressed in this thesis as the negative logarithmic form $\left(\mathrm{pEC}_{50}\right)-$, Hill slope and $E_{\max }$; the bottom parameter was constrained to 0 whilst the other parameters were fitted automatically;

$\mathrm{hP}_{2 \mathrm{Y}_{12}}$ receptor transfected cells however were tested by studying their response to the $\mathrm{hP}_{2 \mathrm{Y}_{12}}$ receptor antagonist cangrelor using a protocol developed previously in the lab group (see Naughton, 2014). 3 or 4 repeated additions of 300 nM ADP were made at 10 minute intervals to determine if the response was reproducible, and the coverslip then perfused with $1 \mu \mathrm{M}$ of cangrelor for 5 minutes to equilibrate. The $\mathrm{Ca}^{2+}$ response of $300 \mathrm{nM}$ ADP diluted in 1 $\mu \mathrm{M}$ cangrelor was then recorded, and after 5 minutes of washout to remove the antagonist the response to $300 \mathrm{nM}$ ADP alone was tested again; all responses were expressed as a percentage of the second initial $10 \mu \mathrm{M}$ ADP response.

\subsection{4 $\mathrm{Ca}^{2+}$ Flux Imaging with the Molecular Devices FlexStation 3 Platereader}

tsA201 cells were split into clear bottomed, black walled 96 well plates (Corning) at a low density and left to grow until uniformly confluent. Two hours before experimentations the complete media was replaced with serum-free DMEM, and the cells subsequently incubated with $5 \mu \mathrm{M}$ Cal-520 AM as described in section 2.2.2; afterwards the wells were aspirated and filled with $90 \mu \mathrm{l}$ of HEPES-Krebbs buffer, with the plate then loaded in the reading chamber of a Molecular Devices FlexStation 3 robotic platereader. The automated micro fluidics and dispensing system was loaded with the natural hP2Y ligands at 10x the concentrations (to account for serial dilution when added to the $90 \mu$ l buffer already in each well of cells) being tested along with a buffer only control well for each lane. ADP, ATP, UDP and UTP (all from Sigma-Aldrich) were prepared in buffer with the platereader programmed to apply the loaded 
concentrations of each to 3 adjacent lanes of the plate for triplicate reads. Upon running the $\mathrm{Ca}^{2+}$ assay the software (SoftMax Pro 7 ) was set with the excitation and emission frequencies as $490 \mathrm{~nm}$ and $525 \mathrm{~nm}$, to report averaged reads every 3 seconds, apply $10 \mu \mathrm{l}$ of respective agonist to the wells in the lane 17 seconds into each read and finish recording after 300 seconds; the photomultiplier tube sensitivity was set as "high". After the assay had finished the data was automatically transformed in SoftMax Pro to present as maximum minimum and analysed in GraphPad Prism 7, where the data was normalised as a percentage of the response to $10 \mu \mathrm{M}$ of agonist and the "log(agonist) vs. response -- variable slope" equation fitted. The bottom parameter was constrained to the average percent response to buffer only for the three lanes of each agonist, whilst all other equation parameters were fitted automatically up to the maximal response.

\subsubsection{Molecular Biology Techniques}

All molecular biology related work was conducted using RNAse/DNAse free consumables and filtered aerosol resistant pipette tips to avoid degradation or cross contamination of samples.

\subsubsection{RNA Extraction}

After growing to at least $70 \%$ confluence tsA201 cells were passaged with trypsin as previously detailed, centrifuged at 1000 RPM for 5 minutes, the pellet re-suspended in a known volume of complete media and a cell count performed using a haemocytometer to calculate the cell density and total count. After adjusting to approximately $3 \times 10^{6}$ cells in total the cells were then spun down at 1000 RPM for 5 minutes, the supernatants removed and the pellet lysed by addition of a mix of $350 \mu$ Bioline Buffer RLY and $3.5 \mu \mathrm{l} \beta$ mercaptoethanol. The pellet was then vigorously mixed by vortexing until homogenous and RNA extraction proceeded to or the lysate frozen at $-80^{\circ} \mathrm{C}$ for later extraction.

Because of the thick nature of the lysates they were passed through a Qiagen Qiashredder at full centrifuge speed for 2 minutes to homogenise; the standard Bioline Isolate II RNA Mini kit protocol for cultured cells was subsequently used for extraction, including the on-column DNAse I step; the RNA was eluted with $60 \mu$ of RNAse free water. RNA concentration and purity were then assessed through a Nanodrop 2000c spectrophotometer (Thermo Fisher Scientific). 
Because of issues associated with genomic DNA contamination of the eluted RNA, a post DNAse I reaction was further performed on the RNA using NEB DNAse I enzyme (New England Biolabs). NEB DNAse buffer was added to the RNA to a final concentration of $10 \%$ $(\mathrm{v} / \mathrm{v})$ along with $2 \mathrm{U}$ of DNAse I enzyme and the total volume brought up to $100 \mu \mathrm{l}$ with RNAse free water. This was then incubated at $37^{\circ} \mathrm{C}$ for 10 minutes in a Perkin-Elmer DNA Thermal Cycler 480 and the DNAse I was subsequently inactivated by incubation at $75^{\circ} \mathrm{C}$ for 10 minutes; afterward cleanup of the RNA was performed using the Bioline Isolate II RNA mini kit again, following the "RNA cleanup" protocol detailed in the product literature. Concentration and purity were lastly assessed again with the Nanodrop 2000c spectrophotometer: concentrations of $\geq 150 \mathrm{ng} / \mathrm{\mu l}$, and respective $A_{260 / 280}$ and $A_{260 / 230}$ ratios of 2.00 to 2.10 and $\geq 2.00$ were taken as appropriate for further use.

\subsection{2 cDNA Synthesis}

The extracted RNA was subsequently used to prepare cDNA (RT+) with Quanta Biosciences qScript cDNA Supermix. In RNAse free water supermix and RNA were combined on a 1 $\mu \mathrm{l} / 0.25 \mu \mathrm{g}$ ratio and brought up to a total volume of $5 \mathrm{x}$ that of the supermix; no reverse transcriptase (RT-) controls were further prepared identically except for the replacement of the supermix with water. The reactions were placed on a Perkin-Elmer DNA Thermal Cycler 480 programmed to $25^{\circ} \mathrm{C}$ degrees for 5 minutes, $42^{\circ} \mathrm{C}$ for 30 minutes and finally $85^{\circ} \mathrm{C}$ for 5 minutes to inactivate. The cDNA and RT- controls were then stored at $-20^{\circ} \mathrm{C}$ until use.

For one application, $50 \mathrm{U}$ of NEB RNAse $\mathrm{I}_{\mathrm{f}}$ was applied to half the volumes of newly synthesised RT+ and RT- templates to remove present RNA, with the samples incubated at $37^{\circ} \mathrm{C}$ for 30 minutes; the remaining volumes of the templates were not treated with the enzyme, but were still subjected to the incubation.

\subsubsection{Reverse Transcriptase Polymerase Chain Reaction}

The produced cDNA was subsequently amplified by polymerase chain reaction. Primers designed against all the hP2Y receptor subtypes were utilised as detailed in Table 3; these would therefore amplify the product sequences listed in Table 4. 
Table 3: Primer sequences used for the RT-PCR

\begin{tabular}{llll}
\hline $\begin{array}{l}\text { Receptor } \\
\text { Gene }\end{array}$ & Forward (sense) primer & Reverse (anti-sense) primer & $\begin{array}{l}\text { Product } \\
\text { Size (bp) }\end{array}$ \\
\hline hP2Y1 & CTTGGCGGGAGATACTTTCAG & CACAGGCTTGTATCTCCATTCTG & 147 \\
\hline hP2Y2 & CCTTTACTGCAGCATCCTCTTC & CAGCACCAACACCCACAC & 139 \\
\hline hP2Y4 & GTGAGGGAACCCAATAGTGATAC & AAAGAGTCGGCAACTGAAGG & 147 \\
\hline hP2Y6 & ACATCACCAAGACAGCCTAC & CTGGGTGAAGTAGAAGAGGATG & 149 \\
\hline hP2Y11 & GGAACTGGGTAGCAGACAC & TGGAACCCACTGAGTTTGTC & 122 \\
\hline hP2Y12 & ATGCCTGGATCCGTTCATC & TCATTTGGGTCACCACCATC & 141 \\
\hline hP2Y13 & ATGACTGCCGCCATAAGAAG & TGTACTATCCGAGTGTCTCTGG & 131 \\
\hline hP2Y14 & TTTACGTGCCCAGCTCTAAG & CTGCACACAAACACGTTCAG & 142 \\
\hline
\end{tabular}


Table 4: Sequences amplified by the RT-PCR primers

\begin{tabular}{|c|c|}
\hline $\begin{array}{l}\text { Receptor } \\
\text { Gene }\end{array}$ & Amplified Sequence \\
\hline \multirow[t]{3}{*}{$\mathrm{hP}_{2} \mathrm{Y}_{1}$} & CGGCTGTCTACATCTTGGTATTCATCATCGGCTTCCTGGGCAACAGCGTGGCCATCTGGATGTT \\
\hline & CGTCTTCCACATGAAGCCCTGGAGCGGCATCTCCGTGTACATGTTCAATTTGGCTCTGGCCGAC \\
\hline & TTCTTGTACGTGCTGACTCTG \\
\hline \multirow[t]{2}{*}{$\mathrm{hP}_{2} \mathrm{Y}_{2}$} & ССTTTACTGCAGCATCCTCTTCCTCACCTGCATCAGCGTGCACCGGTGTCTGGGCGTCTTACGA \\
\hline & ССтCTGCGCTCCCTGCGCTGGGGCCGGGCCCGCTACGCTCGCCGGGTGGCCGGGGCCG \\
\hline \multirow[t]{3}{*}{$\mathrm{hP}^{2} \mathrm{Y}_{4}$} & GTGAGGGAACCCAATAGTGATACCTGGTAAGGTGCTTCTTCCTCTTTTCCAGGCTCTGGAGAGA \\
\hline & AGCCCTCACCCTGAGGGTTGCAGGGAGGCAGGGATATCATGGGTGACCTCATCTCTCATAACCC \\
\hline & CTTCAGTTGCCGACTCTTT \\
\hline \multirow[t]{3}{*}{$\mathrm{hP}_{2 \mathrm{Y}_{6}}$} & ACATCACCAAGACAGCCTACCTGGCAGTGCGCTCGACGCCGGGCGTCCCCTGCACTGTATTGGA \\
\hline & GGCCTTTGCAGCGGCCTACAAAGGCACGCGGCCGTTTGCCAGTGCCAACAGCGTGCTGGACCCC \\
\hline & АТССТСTTCTACTTCACCCAG \\
\hline \multirow[t]{2}{*}{$\mathrm{hP} 2 \mathrm{Y}_{11}$} & GGAACTGGGTAGCAGACACAGGCTGAGGATCGGCACGGGAGCATGGCAGCCAACGTCTCGGGTG \\
\hline & CCAAGTCCTGCCCTGCCAACTTCTTGGCAGCTGCCGACGACAAACTCAGTGGGTTCCA \\
\hline \multirow[t]{3}{*}{$\mathrm{hP} 2 \mathrm{Y}_{12}$} & ATGCCTGGATCCGTTCATCTATTTTTTCCTTTGCAAGTCCTTCAGAAATTCCTTGATAAGTATG \\
\hline & CTGAAGTGCCCCAATTCTGCAACATCTCTGTCCCAGGACAATAGGAAAAAAGAACAGGATGGTG \\
\hline & GTGACCCAAATGA \\
\hline \multirow[t]{3}{*}{$\mathrm{hP2Y_{13 }}$} & ATGACTGCCGCCATAAGAAGACAGAGAGAACTGAGTATCCTCCCAAAGGTGACACTGGAAGCAA \\
\hline & TGAACACCACAGTGATGCAAGGCTTCAACAGATCTGAGCGGTGCCCCAGAGACACTCGGATAGT \\
\hline & $\mathrm{ACA}$ \\
\hline \multirow[t]{3}{*}{$\mathrm{hP}^{2 Y_{14}}$} & TTTACGTGCCCAGCTCTAAGAGTTTCATCATCTATCTCAAGAACATTGTTATTGCTGACTTTGT \\
\hline & GATGAGCCTGACTTTTCCTTTCAAGATCCTTGGTGACTCAGGCCTTGGTCCCTGGCAGCTGAAC \\
\hline & GTGTTTGTGTGCAG \\
\hline
\end{tabular}

The primers were designed to amplify the above sequences for each receptor when used in RT-PCR; these sequences were also compared with the Sanger sequenced gel bands (see section 2.3.5). 
After preliminary experiments with several polymerases, Promega GoTaq Green Hotstart PCR Mastermix polymerase was used for the amplification. The components were combined in $0.2 \mathrm{ml}$ thin wall PCR tubes on a ratio of 12.5 volumes of polymerase per 1 volume of template, with $0.4 \mu \mathrm{M}$ of each of the respective forward and reverse primers and brought up to a total volume twice that of the polymerase with RNAse free water; this was individually adjusted however when needed for specific targets. The templates used were cDNA (RT+), in addition to RT- and water controls: these were to respectively amplify the target nucleotide sequence if present on the cDNA, identify any contaminants in the RNA and identify contamination or off-target effects produced exclusively by the reaction components. The combined components were then subsequently placed in a Primus 96 Plus thermal cycler (MWG Biotech AG) programmed for 2 minutes of initial denaturation at $95^{\circ} \mathrm{C}$, and then 35 cycles of denaturation at $95^{\circ} \mathrm{C}$ for 45 seconds, 30 seconds of annealing at $55^{\circ} \mathrm{C}$ and 30 seconds of extension at $72^{\circ} \mathrm{C}$. After the final cycle there was an additional final extension at $72^{\circ} \mathrm{C}$ for 5 minutes before the reactions were held at $8^{\circ} \mathrm{C}$. Afterwards the PCR reactions were stored at $-20^{\circ} \mathrm{C}$ until use or agarose gel electrophoresis immediately proceeded to.

Positive control reactions were further prepared as above, using as the template either $1 \mathrm{ng}$ of plasmid containing the receptor cDNA sequence or cDNA isolated from cells endogenously expressing the required receptor mRNA. Due to challenges encountered with the plasmids potentially contaminating reaction components, all PCR reactions were eventually made up in a class II hood which had been exposed to short wavelength UVc light for 20 minutes to remove any DNA aerosols, and the positive controls were not opened in the presence of other reaction component stocks. The positive control PCR reactions were prepared separately using different pipettes to avoid contamination of the source templates and other reagents.

The following positive controls were used for each receptor subtype gene (Table 5): 
Table 5: RT-PCR hP2Y receptor positive control templates

\begin{tabular}{|c|c|}
\hline $\begin{array}{l}\text { Receptor } \\
\text { Gene }\end{array}$ & Control \\
\hline $\mathrm{hP2Y_{1 }}$ & hP2Y 1 -YFP plasmid \\
\hline $\mathrm{hP} 2 \mathrm{Y}_{2}$ & hP2Y $2-H A$ plasmid \\
\hline $\mathrm{hP}_{2} \mathrm{Y}_{4}$ & 1321N1-hP2Y 4 receptor cells mRNA \\
\hline $\mathrm{hP}_{2} \mathrm{Y}_{6}$ & Hep-G2 cells mRNA \\
\hline $\mathrm{hP}_{2 \mathrm{Y}_{11}}$ & $\mathrm{hP}_{2 \mathrm{Y}_{11} \text { plasmid }}$ \\
\hline $\mathrm{hP} 2 \mathrm{Y}_{12}$ & hP2Y ${ }_{12}-$ CFP plasmid \\
\hline $\mathrm{hP}_{2} \mathrm{Y}_{13}$ & $\mathrm{hP}_{2} \mathrm{Y}_{13}$ plasmid \\
\hline $\mathrm{hP}_{2 \mathrm{Y}_{14}}$ & $\mathrm{hP}_{2 Y_{14}-\mathrm{HA} \text { plasmid }}$ \\
\hline
\end{tabular}

\subsubsection{Agarose Gel Electrophoresis}

Agarose gels were prepared by dissolving molecular grade agarose (Bioline) in 1x TrisBorate-EDTA (TBE) buffer (UltraPure 10x TBE buffer, Thermo Fisher Scientific) to the percentage required: typically $2 \%(\mathrm{w} / \mathrm{v})$ gels were prepared, but for some applications $1 \%$ $(\mathrm{w} / \mathrm{v})$ gels were also used. This mixture was weighed, then boiled in a $900 \mathrm{~W}$ microwave until the agarose had dissolved and distilled water added to make up any volume lost through convection. After allowing to cool for a few minutes, ethidium bromide (Sigma-Aldrich) was added to the dissolved agarose to a concentration of $0.4 \mu \mathrm{g} / \mathrm{ml}$ and the solution gently poured into the gel tank (Bioscience Services Mini Q) to a thickness of $6 \mathrm{~mm}$ with a 16 well ( $5 \mathrm{~mm} \times 5 \mathrm{~mm} \times 1 \mathrm{~mm}$ per tooth) comb then carefully added; the gel was allowed to set at room temperature for at least 30 minutes. Running buffer was prepared by addition of ethidium bromide to $1 \mathrm{x}$ TBE buffer to a final concentration of $0.625 \mu \mathrm{g} / \mathrm{ml}$, this was added to the tank with the gel submerged to a final depth of $6 \mathrm{~mm}$ after the comb was removed. $15 \mu \mathrm{l}$ of sample was loaded per well in addition to one or two lanes with $5 \mu$ l of DNA size ladder (Bioline Hyperladder $1 \mathrm{~kb}$ or $100 \mathrm{bp}$ ); the power supply electrodes were attached to the tank and the electrophoresis ran at $4.0-4.5 \mathrm{~V} / \mathrm{cm}$ until the yellow tracking dye had ran off the bottom. The gel was then removed from the tank to an enclosed UV transilluminator where it was photographed with a Pulnix TM-300 (JAI) imaging system and Syngene Genesnap software. Adjustments to global image brightness, contrast and density were made in Adobe Photoshop Elements 8.0. 


\subsubsection{Gel Band Purification and Sanger Sequencing}

In order to confirm the identity of the expressed bands on the agarose gels, the bands were excised, purified and sequenced by the Sanger method (Sanger et al., 1977). Sufficient volumes of PCR reactions were prepared to load 3 adjacent wells of a gel with $15 \mu$ leach of the product; initially $1 \%$ agarose gels were used, but shortly $2 \%$ gels were used so to maximise the separation between bands. Following gel electrophoresis the gels were visualised on a UV transilluminator, and a scalpel used to carefully excise the bands of interest and remove as much exogenous agarose as possible. The excised DNA in the bands was then purified, initially using a Sigma GenElute Gel Extraction Kit as per the manufacturer's instructions and eluting with $25 \mu \mathrm{l}$ of RNAse free water. Because of poor yields that frequently failed to sequence, later purifications were made using an llustra GFX PCR DNA and Gel Band Purification kit (GE Healthcare) with the protocol recommended in the product literature; the DNA was eluted with $40 \mu \mathrm{l}$ of RNAse free water and then passed back through the spin column membrane to concentrate. After concentration measurement on the Nanodrop 2000c spectrophotometer the purified DNA was sent to GATC Biotech along with samples of the respective forward and reverse primers - for Sanger sequencing using their "SUPREMErun" service.

The received sequences were subsequently viewed in FinchTV V1.4.0 (Geospiza Inc, available at http://www.geospiza.com/ftvdlinfo.html), with poor quality bases at the beginning/end of each read being removed before exporting the sequence in FASTA format (with reverse reads converted to the reverse complement). Subsequently the NCBI nucleotide Mega "Basic Local Alignment Search Tool" (BLAST) was used to search for highly similar sequences. The Human Genomic and Transcript databases were searched and the default options used except for disabling low-complexity regions filtering.

The forward and reverse read sequences were afterwards aligned with each other and the expected PCR product sequence using the European Bioinformatics Institute (EBI) MUltiple Sequence Comparison by Log- Expectation (MUSCLE) (available at http://www.ebi.ac.uk/Tools/msa/muscle/). These were exported in the GCG MSF format for

processing with Boxshade (available at http://www.ch.embnet.org/software/BOX_form.html) to highlight similarity, selecting the "RTF new" format and setting "fraction of sequences" as 0.05 . 


\subsubsection{Verification of the tsA201 Cell Line by Short Tandem Repeats}

A short tandem repeats (STR) test was performed on the cells being maintained, in order to confirm the identity of the tsA201 cells prior to undertaking future experimentations. $90 \%$ confluent cells in a T75 were detached with trypsin and collected as previously described; after a cell count and centrifuging down at 5000 RPM for 5 minutes the resulting pellet was re-suspended in DMEM to a volume equal to $1000 \mathrm{cells} / \mu \mathrm{l}$ and $100 \mu \mathrm{l}$ of cells then applied to the collection card supplied by Public Health England for the test. After allowing to air dry for 2 hours the card was sent to Public Health England for STR cell line validation and the resulting profile compared with that deposited in the European Collection of Authenticated Cell Cultures.

\subsubsection{Co-immunoprecipitation and Western Blotting}

\subsubsection{Immunoprecipitation}

After 48 hours of growth and reaching confluence, transfected $60 \mathrm{~mm}$ dishes of tsA201 cells (expressing either singular or co-expressed transfected receptors) were washed with ice cold phosphate buffered saline (PBS), placed on ice and then lysed by addition of lysis buffer (50 $\mathrm{mM}$ Tris- $\mathrm{HCl}$ pH 7.4, 1\% Triton-X-100 plus Roche Mini Protease Inhibitor cocktail 1 tablet/10 $\mathrm{ml}$ added on the day of the experiment). The cells were scraped down and passed several times through a $21 \mathrm{G}$ or $23 \mathrm{G}$ syringe to break up clumps before being transferred to $1.5 \mathrm{ml}$ tubes. The lysates were left to rotate end over end at $40 \mathrm{RPM}$ in a $4^{\circ} \mathrm{C}$ atmosphere for at least 60 minutes, then spun down at 10000 RPM for 10 minutes in a $4^{\circ} \mathrm{C}$ atmosphere to pellet any cellular debris that had not lysed. The supernatants - crude whole cell lysates were removed to new tubes and $50 \mu$ of each was subsequently placed in another set of tubes along with $50 \mu \mathrm{l}$ of $2 x$ NuPage- lithium dodecyl sulphate (LDS) sample buffer (Thermo Fisher Scientific) plus $50 \mathrm{mM}$ dithiothreitol (DTT); these were then boiled at $95^{\circ} \mathrm{C}$ for 2 minutes to denature, providing the "input" samples.

The lysates were pre-cleared with Calbiochem Protein G Plus/Protein A Agarose Suspension (Merck Millipore). $20 \mu \mathrm{l}$ of beads were placed in new tubes and washed twice with lysis buffer before the supernatants were removed to leave the washed pellets. $300 \mu \mathrm{l}$ of each whole cell lysate was added to a tube of beads and left to rotate end over end in a $4^{\circ} \mathrm{C}$ 
atmosphere for at least 60 minutes before being pelleted by centrifugation and the precleared supernatants transferred into new tubes.

$20 \mu \mathrm{l}$ per sample of the respective agarose immunoprecipitation beads - anti-HA-agarose produced in mouse (Sigma-Aldrich) for HA immunoprecipitation and GFP-Trap (ChromoTek) for GFP - were washed twice with lysis buffer to remove any residual storage buffer, the supernatants were then removed and $300 \mu \mathrm{l}$ of each pre-cleared lysate added. These were left to rotate overnight at $40 \mathrm{RPM}$ in a $4^{\circ} \mathrm{C}$ atmosphere, the next day the bead-lysate complexes were washed 3 times with lysis buffer to remove any un-bound protein before being pelleted by centrifugation and the supernatants removed. For the GFP immunoprecipitations only, $30 \mu \mathrm{l}$ was removed from each to separate tubes and $30 \mu \mathrm{l} 2 \mathrm{x}$ NuPage-LDS sample buffer plus $50 \mathrm{mM}$ DTT added to elute the immunoprecipitated (IP) complexes; these samples were then boiled at $95^{\circ} \mathrm{C}$ for 2 minutes to denature. For $\mathrm{HA}$ immunoprecipitations the HA tagged proteins were eluted with 30-40 $\mu \mathrm{l} \mathrm{of} 200 \mu \mathrm{g} / \mathrm{ml} \mathrm{HA-}$ Peptide (Sigma-Aldrich), which was added to the washed bead-lysate complexes, gently vortexed and then left at room temperature for 20 minutes, lightly vortexing every 3 minutes. The tubes were then centrifuged at 5000 RPM for 5 minutes and the supernatants - IP samples - were carefully transferred to new tubes. Both the IP samples and the leftover beads - HA-peptide controls - then had 2x NuPage-LDS sample buffer plus 50 mM DTT added at the same volume as the HA-peptide and were subsequently boiled at $95^{\circ} \mathrm{C}$ for 2 minutes to denature.

\subsubsection{SDS-PAGE and Western Blotting}

The Biorad Mini-Protean Tetra system was used for Western blotting. 15-20 $\mu$ l of sample per lane were separated by $8.5 \%$ resolving gels $(30 \%[\mathrm{w} / \mathrm{v}]$ acrylamide, $0.8 \%[\mathrm{w} / \mathrm{v}]$ bisacrylamide in $380 \mathrm{mM}$ Tris-HCL pH 8.8, 0.10\% [w/v] sodium dodecyl sulphate [SDS]). 0.02\% $(\mathrm{w} / \mathrm{v})$ ammonium persulfate (APS) and $0.02 \%(\mathrm{v} / \mathrm{v})$ tetramethylethylenediamine (TEMED) were added to these components to polymerise the gel, which was quickly poured between pre-assembled $1.0 \mathrm{~mm}$ (medium) glass plates (Biorad) with a thin layer of $100 \%$ isopropanol on top to ensure level setting and give an indication of when the gel had set. After setting the isopropanol was washed out with distilled water and exogenous liquid gently drawn out with filter paper; the $4 \%$ stacking gel $(30 \%[\mathrm{w} / \mathrm{v}]$ acrylamide, $0.8 \%[\mathrm{w} / \mathrm{v}]$ bis-acrylamide diluted in $123 \mathrm{mM}$ tris-HCL $\mathrm{pH}$ 6.6, 0.01\% [w/v] SDS, 0.1\% [w/v] APS, 0.07\% [v/v] TEMED) was quickly poured on top of the resolving gel and a $1.0 \mathrm{~mm} 10$ or 15 well comb (Biorad) inserted gently between the plates and into the stacking gel. After the stacking gel had set the plates 
were transferred to Biorad Mini-Protean Tetra electrophoresis holders, placed in the electrophoresis chamber and the comb removed; the tank was then filled with running buffer (25 mM Tris, $192 \mathrm{mM}$ Glycine, $3.5 \mathrm{mM}$ SDS) up to the respective level for the number of gels. The samples were loaded with a Hamilton micro-syringe along with a lane of prestained protein standards ladder (Thermo Fisher Scientific); the chamber between the plates was topped up with running buffer before running the electrophoresis at $115 \mathrm{~V}$ until the bromophenol blue tracking dye had ran off the bottom of the gel.

The gels were subsequently transferred to polyvinylidene difluoride (PVDF) membranes with the Biorad Mini Trans-blot system. The membranes were activated by soaking in $100 \%$ methanol until translucent, followed by ice cold transfer buffer (25 mM tris, $192 \mathrm{mM}$ glycine, $20 \%$ methanol [v/v]). All components for the transfer were soaked in ice cold transfer buffer and each transfer cassette arranged with the bottom side of the cassette down followed by 3 $\mathrm{mm}$ sponge, $1 \mathrm{~mm}$ filter paper, the gel, the activated membrane, $1 \mathrm{~mm}$ filter paper and $1 \mathrm{~mm}$ sponge. The cassette was closed and inserted into the Biorad Mini Tran-blot Cell transfer chamber along with a cooling bath of frozen transfer buffer and the chamber filled to the level of the cassette clip with transfer buffer. The power supply was set to run at $300 \mathrm{~mA}$ for 105 minutes before the cassette was removed, the membrane extracted and put to block in $2 \%$ $(\mathrm{w} / \mathrm{v}$ ) bovine serum albumin (BSA) (diluted in 0.03\% NATT buffer: $300 \mathrm{mM} \mathrm{NaCl}, 40 \mathrm{mM}$ tris, $0.03 \%$ [v/v] Tween-20, pH7.4) on an orbital shaker at room temperature for at least 2 hours. The primary antibody - in $0.2 \%$ (w/v) BSA diluted in $0.03 \%$ NATT buffer - was then applied either by heat sealing the membrane in a plastic liner with the antibody or by adding the antibody directly to the membranes container. Preferentially the antibody was left to bind overnight (>12 hours) at room temperature on an orbital shaker, but in some cases where this was not possible the primary antibody was left to bind for at least 2 hours. The primary antibodies that were used are detailed in Table 6:

Table 6: Primary antibodies used for Western blotting

\begin{tabular}{llll}
\hline Antibody & Supplier & Species & Dilution \\
\hline Anti-aGFP & Chromobio & Rat & $1: 1000$ \\
\hline Anti-HA & BioLegend & Mouse & $1: 5000 / 1: 10000$ \\
\hline Anti- $\beta$-tubulin & Sigma-Aldrich & Mouse & $1: 3333$ \\
\hline
\end{tabular}

After the primary antibody had been applied for sufficiently long the membranes were washed in $0.03 \%$ NATT buffer 4 times at 15 minute intervals; horseradish peroxidase (HRP) conjugated secondary antibody for the respective species of the primary antibody was applied at 1:3333 dilution in $0.2 \%(w / v)$ BSA for at least an hour and half at room 
temperature on an orbital shaker before another 4 washes were undertaken. Enhanced chemiluminescence (ECL) was then used for detection: ECL-1 (100 mM Tris-HCL pH 8.5, $2.5 \mathrm{mM}$ luminol, $1.15 \mathrm{mM}$ coumaric acid) and ECL-2 (100 mM Tris-HCL pH 8.5, 0.064\% [v/v] $\mathrm{H}_{2} \mathrm{O}_{2}$ ) were applied to the membrane on a $1: 1$ basis to activate the conjugated HRP. The membranes were then placed in an exposure cassette beneath plastic wrap, and under safelight conditions exposed on UltraCruz autoradiography film (Santa Cruz Biotechnology), which was processed in a Kodak M-35M X-OMAT processor. The film was then scanned on a HP Deskjet 2540 and adjustments to the images global brightness, contrast and density were made in Adobe Photoshop 8.0.

\subsubsection{PVDF Membrane Stripping}

In order to re-probe the PVDF membranes they were stripped of any bound antibodies using Restore Western Blot Stripping Buffer (Thermo Fisher Scientific) at room temperature for 15 minutes on an orbital shaker. Unfortunately, this did not sufficiently remove higher affinity antibodies such as anti-HA or anti- $\beta$-tubulin and extending the incubation time did not improve removal; using it at $37^{\circ} \mathrm{C}$ as recommended in the product literature was associated with both the antibodies and proteins being removed from the membrane. It was therefore necessary in some cases to re-run samples on separate membrane or probe with antibodies in a strict order.

\section{$\underline{\text { 2.5.0 Statistical Analysis }}$}

All statistical analysis was undertaken in GraphPad Prism 7. The fitted parameters of different concentration-response curves were statistically compared with non-linear regression using the "compare" function with the extra sum of squares F test (ESSFT); $p$ values of $\leq 0.05$ were taken as statistically significant and the Holm-Sidak correction used to account for multiple comparisons.

The transfected $\mathrm{hP}_{2} \mathrm{Y}_{12}$ receptors responses were evaluated by first analysing the timecourse of the 3 or 4 repeated 300 nM ADP control responses with linear regression to determine if the repeated stimulation caused any overall changes in response by the cells. The repeated $300 \mathrm{nM}$ ADP responses were then averaged, and two-way analysis of variance (ANOVA) used to compare these responses to those of $300 \mathrm{nM}$ ADP both during and after cangrelor being present. The responses factor was set as repeated measures and the differently tagged plasmids as the second factor; when there was an overall significant 
difference for the factor and no significant interaction between the two factors multiple comparisons were made with a post-hoc Tukey test; $p$ values of $\leq 0.05$ were taken as statistically significant. 
Chapter 3: Results 


\subsubsection{Cell Line Verification by Short Tandem Repeats}

After receiving the cell line verification by short tandem repeats (STR) results, the received values for each genetic loci were compared to those listed for the tsA201 cell line by the European Collection of Authenticated Cell Cultures, and are both detailed in Table 7. The loci values were additionally checked against the German Collection of Microorganisms and Cell Cultures Profile Database (available at https://www.dsmz.de/services/services-humanand-animal-cell-lines/online-str-analysis.html) to identify if they could also correspond to other cell lines. Although there was a complete match with that of HEK-293 derived Hkb2O cells (score 1.00), the tsA201 line was unfortunately not listed in the database. All of the cell lines with a score of $>0.80$ were HEK-293 derivatives, which is reflective of their high degree of similarity, but regrettably no reference profile for the tsA201 cell line could be found in other databases using the full 18 loci received as the cells have not been commonly deposited in cell banks. Based on the fact that the cells were behaving functionally identically to those in previous experimentations in the lab group using the cell line, it was decided to proceed based on them being tsA201 cells. 
Table 7: The received and the reference European Collection of Authenticated Cell Cultures Short Tandem Repeats profiles for the tsA201 cells.

\begin{tabular}{|c|c|c|}
\hline Loci & Received Profile & ECACC Reference Profile \\
\hline Amelogenin & $\overline{X, X}$ & $\overline{X, X}$ \\
\hline vWA & 16,19 & 16,19 \\
\hline D16S539 & 9,13 & 9,13 \\
\hline CSF1PO & 11,12 & 11,12 \\
\hline TPOX & 11,11 & 11,11 \\
\hline TH01 & $7,9.3$ & $7,9.3$ \\
\hline D5S818 & 8,9 & 8,9 \\
\hline D13S317 & 12,12 & 12,12 \\
\hline D7S820 & 11,11 & 11,11 \\
\hline FGA & 23,23 & \\
\hline D3S1358 & 15,17 & \\
\hline D2S1338 & 19,19 & \\
\hline Penta D & 9,10 & \\
\hline Penta E & 7,15 & \\
\hline D8S1179 & 12,14 & \\
\hline D21S11 & $28,30.2$ & \\
\hline D18S51 & 17,18 & \\
\hline D19S433 & 18,18 & \\
\hline
\end{tabular}

DNA from the tsA201 cells being used was screened for various short tandem repeats markers by Public Health England for cell line verification, and the values received are listed as well as those deposited in the European Collection of Authenticated Cell Cultures for the cell line. 


\subsubsection{Endogenous hP2Y Receptor Expression in the tsA201 Cell Line}

\subsubsection{Reverse Transcriptase PCR Revealed the Expression of mRNA for Multiple hP2Y Receptor Subtypes}

The aim of these experiments was to determine the endogenous mRNA expression of the various $\mathrm{hP2Y}$ receptor subtypes in the tsA201 cell line with RT-PCR. As is illustrated in Figures 4A-D, following gel electrophoresis of the PCR reactions strong bands were produced in the RT+ lanes for $h P 2 Y_{1}, h P 2 Y_{12}$ and $h P 2 Y_{14}$; there were also weaker bands expressed in the RT+ lanes for $h P 2 \mathrm{Y}_{2}, \mathrm{hP}_{2} \mathrm{Y}_{4}$ and $\mathrm{hP} 2 \mathrm{Y}_{6}$ receptors, but neither $\mathrm{hP} 2 \mathrm{Y}_{11}$ nor $h P 2 Y_{13}$ receptors expressed $R T+$ bands. All of the RT+ bands shown were of the expected sizes and corresponded with that of the positive controls (the hP2 $Y_{11}$ and $h P 2 Y_{13}$ receptors positive controls however repeatedly failed to show products); they are representative of at least 3 individual experiments, although the positive control bands are only representative of at least a single experiment in some cases as the plasmid templates did not become available until later on in the research. To specifically confirm the RT+ bands identities, the reactions were repeated with the gel bands purified and then Sanger sequenced (see section 3.2.2).

However, in the case of the hP2 $\mathrm{Y}_{1}, 2,12$ receptors (and very inconsistently the hP2 $\mathrm{Y}_{4}, 14$ receptors) there were frequently also weaker bands present in the RT- control lanes. Generally the staining intensity was much weaker compared to the RT+ bands or positive controls, but regularly the $\mathrm{hP} 2 \mathrm{Y}_{12}$ receptor $\mathrm{RT}+$ was only very slightly more intense than the RT- (Figure 4D). The RT-band effect was inconsistent and varied greatly between each PCR reaction: batch to batch variation in the synthesised cDNA and RT- appeared to be at least partially responsible for this. To ascertain the RT- bands identity to determine if they were genomic DNA contamination they were sequenced (see section 3.2.3); using a different DNAse I enzyme (Precision DNAse Kit, Primer Design UK) did not appear to remove or further reduce the bands (data not shown). 

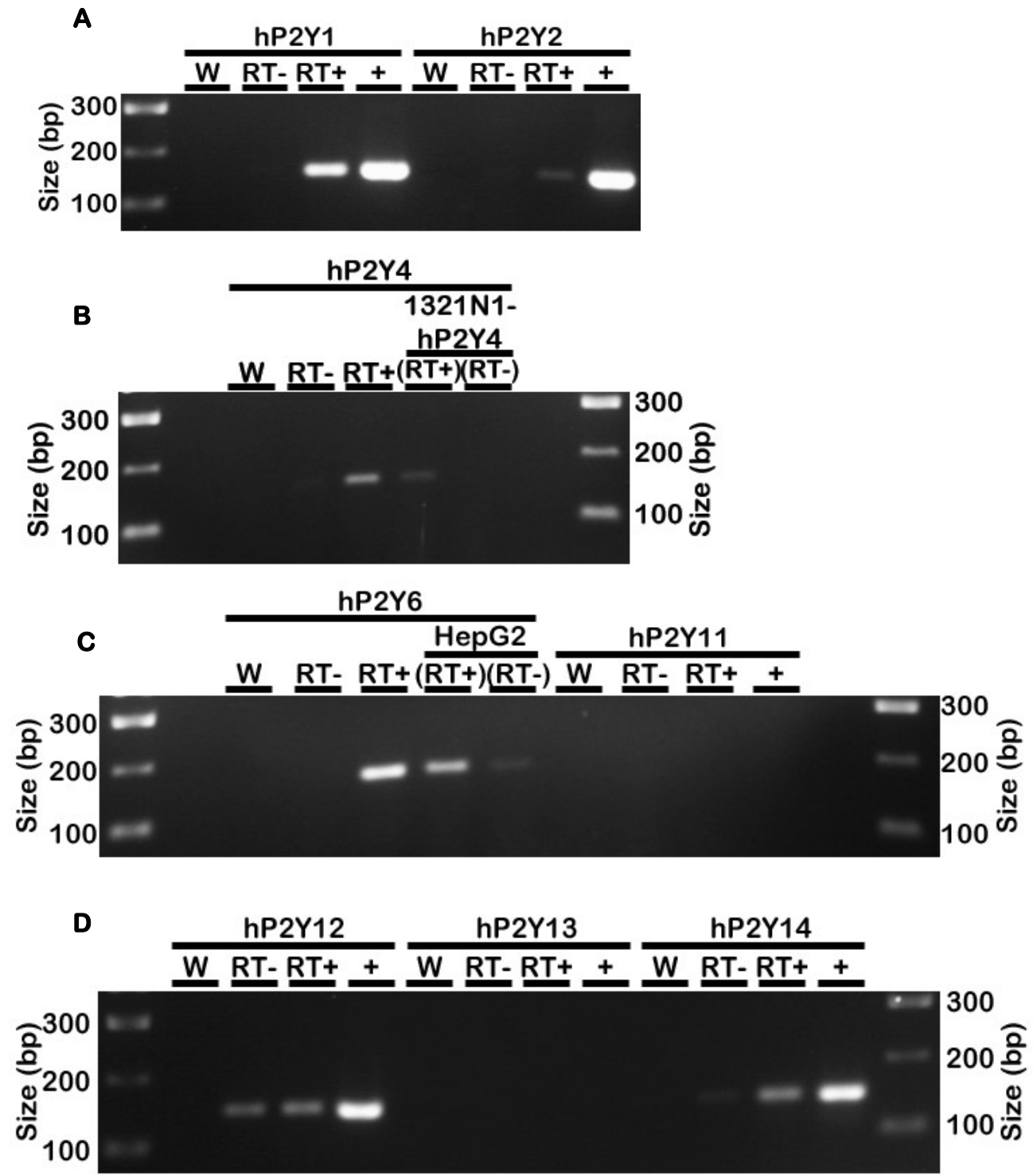

Figure 4: Representative RT-PCR agarose gels of tsA201 hP2Y receptors

Cultured tsA201 cells RNA was extracted, treated with DNAse I enzyme and cDNA then synthesised before amplifying with PCR using gene specific primers (see section 2.3.0) as indicated for (A) hP2Y1, 2 (B) 4 (C) 6, 11 and (D) 12, 13, 14 receptors and running the products on $2 \%(\mathrm{w} / \mathrm{v})$ agarose gels along with $5 \mu \mathrm{LNA}$ size ladder (outermost lanes). Water (W) and RT- control PCR products were additionally prepared and loaded for each receptor type, along with the RT+ product and a positive control reaction using an appropriate plasmid (+) or RT+ and RT- from an appropriate cell line (HepG2 or 1321N1$\mathrm{hP} 2 \mathrm{Y} 4$ cells) to act as a positive control. The RT+ bands are representative of at least 3 independent experiments, whilst the positive control bands are representative of at least 1 independent experiment. 
Although it is accepted to be seen as generally unlikely, it was also tested as to whether the polymerase itself could exhibit reverse transcriptase activity (Figure 5) and hence produce amplicons in the RT- controls. For this RNAse $\mathrm{I}_{\mathrm{f}}$ treated cDNA and RT- were utilised in the standard PCR reaction protocol detailed in section 2.3.3, with $\mathrm{hP} 2 \mathrm{Y}_{1}$ and $\mathrm{hP} 2 \mathrm{Y}_{2}$ receptors as the test subjects due to them both exhibiting consistent RT- bands and the $\mathrm{hP} 2 \mathrm{Y}_{2}$ receptor being typically weaker staining overall. For both replicate PCR reactions where the RNAse treated templates were used, whilst the overall intensity of the RNAse treated RT- was substantially reduced for the $\mathrm{hP}_{2} \mathrm{Y}_{1}$ receptor, the $\mathrm{RT}+$ intensity was relatively unaffected. Unfortunately, the RNAse appeared to have little to no effect on the $\mathrm{hP} 2 \mathrm{Y}_{2}$ receptor RTband density compared to un-treated RT-, and also induced a bright primer-dimer in the treated RT-. In light of these results it was decided that RNAse $I_{f}$ treated cDNA or RTcontrols would not be used in future PCR reactions, although it did raise questions as to why the $\mathrm{hP}_{2} \mathrm{Y}_{1}$ receptor $\mathrm{RT}$ - was reduced in intensity by the enzyme.

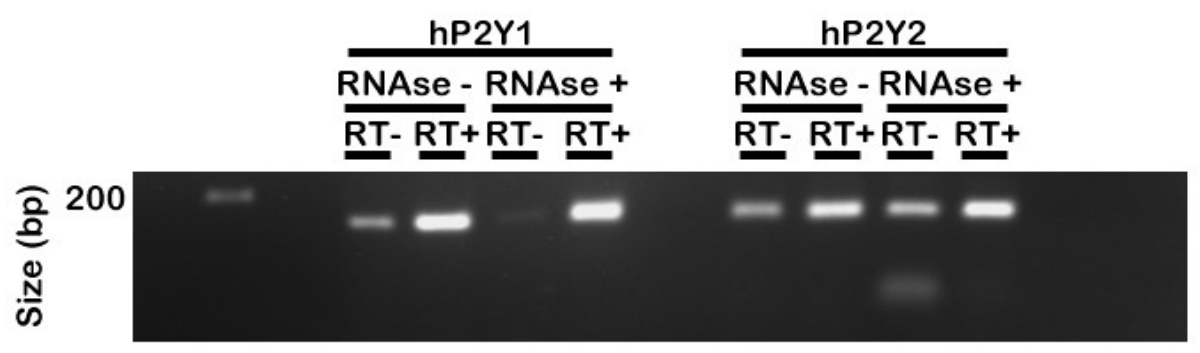

Figure 5: The effect of RNAse $\mathrm{I}_{\mathrm{f}}$ treatment of RT- and RT+ template on $h P 2 \mathrm{Y}_{1}$ and $h P 2 \mathrm{Y}_{2}$ receptor RT- and RT+ staining intensity.

Half the volumes of newly synthesised tsA201 RT- and RT+ templates were treated with $50 \mathrm{U}$ of NEB RNAse $I_{f}$ (RNAse+) and used in PCR reactions with primers for amplifying $\mathrm{hP}_{2} \mathrm{Y}_{1}$ or $\mathrm{hP}_{2} \mathrm{Y}_{2}$ receptor sequences, in addition a second set of reactions was prepared using the remaining volumes of templates which had not been RNAse $I_{f}$ treated (RNAse-). The reactions were then run out on $2 \%(\mathrm{w} / \mathrm{v})$ agarose gels with ethidium bromide staining. This figure is representative of two sets of PCR reactions and agarose gels from the same RT+ and RT- sources. 
Furthermore, signals were inconsistently present in the water controls for hP2 $\mathrm{Y}_{1}$ and $h P 2 \mathrm{Y}_{12}$ receptors and more rarely the $\mathrm{hP}_{2} \mathrm{Y}_{2}$ receptor, with the strength varying from reaction to reaction; these signals would appear with no clear pattern and when using either new or old reaction components. Switching polymerase to GoTaq Green Hotstart Mastermix from the Bioline Mytaq Mix that was first trialled appeared to remove the bands, but they started to appear again after using the GoTaq for a few weeks, suggesting contamination of the reaction mix in some form. Because the bands were of approximately the same sizes as the expected products, steps were taken to exclude aerosol genomic contamination by the plasmid positive controls or previous PCR products as a cause. Toward the end of the project the PCR reactions began to be made up in a Class II hood which had been UVc irradiated for at least 20 minutes to degrade any present DNA and prevent airborne contamination from the outside atmosphere. New, sealed reagents were used which were not opened except in the hood when none of the templates were present. Whilst this appeared to remove the bands in the majority of cases and also reduced the RT- bands, even these measures did not prevent the water amplicons from appearing in some PCR reactions; the exact cause was never entirely satisfactorily determined.

The $\mathrm{hP}_{2} \mathrm{Y}_{11}$ and $\mathrm{hP}_{2} \mathrm{Y}_{13}$ receptor $\mathrm{PCR}$ reactions persistently did not produce any visible products of the expected size, including with the positive controls. To try to determine the reason, PCR reactions against the two receptors were performed, but with the primer concentrations increased to $1 \mu \mathrm{M}$ and $10 \mathrm{ng}$ of each control plasmid used. As a further control a reaction with HepG2 cells cDNA as the template was also included for each as the cell line is reported to express mRNA for both receptors - although the presence of hP2 $\mathrm{Y}_{13}$ receptor mRNA appears to differ between reports (Jacquet et al., 2013; Goree et al., 2014). Unfortunately, these changes failed to produce any products of the expected size and those present were substantially larger (Figure 6), suggesting that either the primers were inappropriate, the plasmids were unsuitable as a positive control and/or the HepG2 cDNA did not express the required mRNA. 


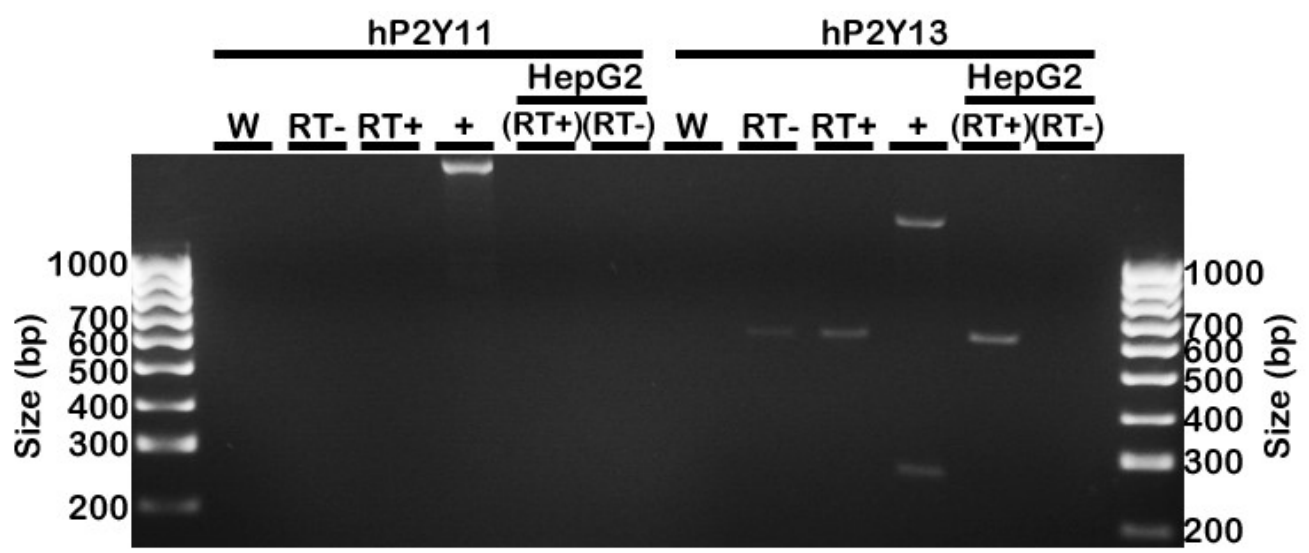

Figure 6: RT-PCR of $\mathrm{hP}_{2} \mathrm{Y}_{11}$ and $\mathrm{hP}_{2} \mathrm{Y}_{13}$ receptor sequences with increased primers concentrations and plasmid template amounts, plus HepG2 cDNA positive controls.

The $\mathrm{hP}_{2} \mathrm{Y}_{11}$ and 13 receptors PCR reactions did not appear to indicate formation of any products of the expected size in the RT+ or plasmid positive controls (+) lanes using the standard protocol, so they were repeated with the primers raised to $1 \mu \mathrm{M}$ each and the plasmid amounts increased to $10 \mathrm{ng}$. Furthermore, a HepG2 RT+ and RT- template reaction was made for each to act as an alternate positive control. These were run out on a $2 \%(\mathrm{w} / \mathrm{v})$ agarose gel with ethidium bromide staining and $5 \mu$ of DNA size ladder (outermost lanes). This is representative of a single experiment. 


\subsubsection{The RT+ Gel Bands Sequences Corresponded to the Expected Targets}

The sequenced $h P 2 Y_{1} R T+$ bands (Figure $7 A$ ) corresponded to that of $h P 2 Y_{1}$ receptor mRNA (accession NM_002563.4) with 100\% nucleotide sequence identity in both the forward and reverse reads; when aligned the reads corresponded with each other and the expected PCR product with no differences. The $h P 2 Y_{2}$ receptors $R T+$ bands sequence (Figure 7B) matched with that of all 3 transcript variants of $\mathrm{hP} 2 \mathrm{Y}_{2}$ receptor mRNA (accession numbers NM_176072.2, NM_176071.2 and NM_002564.3) with 99\% sequence identity in the forward read and $100 \%$ in the reverse. Alignment of the forward and reverse reads for the $\mathrm{hP}_{2} \mathrm{Y}_{2}$ receptor $\mathrm{RT}+$ band sequences revealed them to correspond to each other except for a single base change from $C$ to $A$ in the forward read at position 27 , which would have been responsible for the lower sequence identity in the read. This is not recorded in the GPCR Natural Variants Database (available at http://nava.liacs.nl/index.html) as a known variant of the $\mathrm{hP}_{2} \mathrm{Y}_{2}$ receptor, so it was likely simply a misread base. These reads both aligned precisely with the expected $\mathrm{hP} 2 \mathrm{Y}_{2}$ receptor $\mathrm{PCR}$ product sequence, apart from the aforementioned base change.

However, the reverse $\mathrm{hP} 2 \mathrm{Y}_{2}$ receptor $\mathrm{RT}+$ read also produced a $65 \%$ sequence identity match with 8 of the transcript variants of $\mathrm{hP}_{2} \mathrm{Y}_{6}$ receptor mRNA, although this was only over a small section toward the start of the sequence. When the full length sequences of $h P 2 Y_{2}$ and $\mathrm{hP}_{2} \mathrm{Y}_{6}$ receptors mRNA were aligned with each other in $\mathrm{NCBI}$ nucleotide BLAST, despite having $79 \%$ sequence identity this only covered $6 \%$ of the sequences total lengths (data not shown), and was therefore determined to be the reason for this match.

The sequenced $\mathrm{hP}_{2} \mathrm{Y}_{4}$ receptor $\mathrm{RT}+$ bands (Figure $7 \mathrm{C}$ ) corresponded to $\mathrm{hP} 2 \mathrm{Y}_{4}$ receptor mRNA (accession number NM_002565.3) with 100\% sequence identity for both the forward and reverse reads. Additionally, sequencing of the purified $\mathrm{hP}_{2} \mathrm{Y}_{6}$ receptor RT+ bands (Figure 7D) revealed a sequence which corresponded to 8 transcript variants (accession numbers NM_176797.2, NM_176798.2, NM_176796.2, NM_001277204.1, NM_001277205.1, NM_001277206.1, NM_001277207.1, NM_001277208.1) of hP2Y6 receptor mRNA, with $100 \%$ sequence identity for all in both the forward and reverse reads. For both the $\mathrm{hP}_{2} \mathrm{Y}_{4}$ and $\mathrm{hP} 2 \mathrm{Y}_{6}$ receptor $\mathrm{RT}+$ bands their respective forward and reverse reads aligned with each other with no missing or changed bases, and furthermore aligned with their expected PCR product sequences. 
The purified $\mathrm{hP}_{2} \mathrm{Y}_{12}$ receptor $\mathrm{RT}+$ bands sequence (Figure $7 \mathrm{E}$ ) matched with that of both $\mathrm{hP}_{2} \mathrm{Y}_{12}$ receptor mRNA transcript variants (accession numbers NM_176876.2 and NM_022788.4) with 100\% sequence identity in the forward read, and $99 \%$ for the reverse read due to a single missing base. Additionally, the sequenced $\mathrm{hP}_{2} \mathrm{Y}_{14}$ receptor RT+ bands (Figure 7F) corresponded to the sequences for both known transcript variants of hP2Y 14 receptor mRNA (Accession numbers NM_001081455.1 and NM_014879.3) with 100\% sequence identity in both the forward and reverse reads. For both of the receptors the respective forward and reverse reads were complementary, and further they matched with their expected PCR products with no differences apart for the missing base in the hP2 $\mathrm{Y}_{12}$ receptor reverse read. 


\section{A}

hP2Y1 RT+ Reverse

1 TCTTGGCGGGAGATACTTTCAGAAGGAGACTCTCCCGAGCCACAAGGAAAGCTTCTAGAA

P2Y1 RT+ Forward

1 -------------------------------------------- CTTCTAGAA

hP2Y1 PCR Product

1 -CTtgGCGgGAGATACTTTCAGAAGGAGACTCTCCCGAGCCACAAGGAAAGCTTCTAGAA

hP2Y1 RT+ Reverse

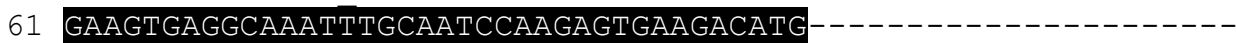

hP2Y1 RT+ Forward

10 GAAGTGAGGCAAATTTGCAATCCAAGAGTGAAGACATGACCCTCAATATTTTACCTGAGT

hP2Y1 PCR Product

60 GAAGTGAgGCAAATTTGCAATCCAAGAGTGAAGACATGACCCTCAATATTTTACCTGAGT

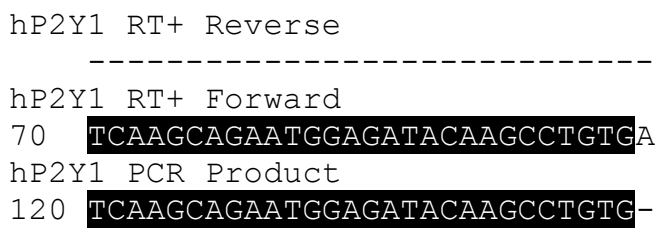

hP2Y1 RT+ Forward

70 TCAAGCAGAATGGAGATACAAGCCTGTGA

hP2Y1 PCR Product

120 TCAAGCAGAATGGAGATACAAGCCTGTG-

\section{B}

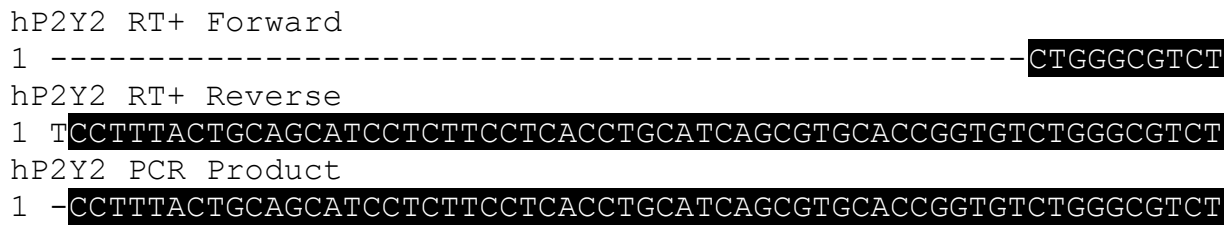




\section{C}

hP2Y4 RT+ Reverse

1 GTGAGGGAACCCAATAGTGATACCTGGTAAGGTGCTTCTTCCTCTTTTCCAGGCTCTGGA

hP2Y4 RT+ Forward

$1---------------------------------------------$ GGCTCTGGA

hP2Y4 PCR Product

1 GTGAGGGAACCCAATAGTGATACCTGGTAAGGTGCTTCTTCCTCTTTTCCAGGCTCTGGA

hP2Y4 RT+ Reverse

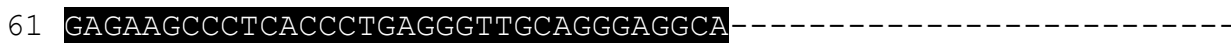

hP2Y4 RT+ Forward

10 GAGAAGCCCTCACCCTGAGGGTTGCAGGGAGGCAGGGATATCATGGGTGACCTCATCTCT

hP2Y4 PCR Product

61 GAGAAGCCCTCACCCTGAGGGTTGCAGGGAGGCAGGGATATCATGGGTGACCTCATCTCT

hP2Y4 RT+ Reverse

---------------------------

hP2Y4 RT+ Forward

70 CATAACCCCTTCAGTTGCCGACTCTTT

hP2Y 4 PCR Product

121 CATAACCCCTTCAGTTGCCGACTCTTT

\section{D}

hP2Y6 RT+ Forward

$1-----------------------------------------$ TGCACTGTAT

hP2Y6 RT+ Reverse

1 ACATCACCAAGACAGCCTACCTGGCAGTGCGCTCGACGCCGGGCGTCCCCTGCACTGTAT hP2Y6 PCR Product

1 ACATCACCAAGACAGCCTACCTGGCAGTGCGCTCGACGCCGGGCGTCCCCTGCACTGTAT

hP2Y6 RT+ Forward

11 TGGAGGCCTTTGCAGCGGCCTACAAAGGCACGCGGCCGTTTGCCAGTGCCAACAGCGTGC

hP2Y6 RT+ Reverse

61 TGGAGGCCTTTGCAGCGGCCTACAAAGGCACGCGGC

hP2Y6 PCR Product

61 TGGAGGCCTTTGCAGCGGCCTACAAAGGCACGCGGCCGTTTGCCAGTGCCAACAGCGTGC

hP2Y6 RT+ Forward

71 TGGACCCCATCCTCTTCTACTTCACCCAGA

hP2Y 6 RT+ Reverse

hP2Y 6 PCR Product

121 TGGACCCCATCCTCTTCTACTTCACCCAG- 


\section{$\mathbf{E}$}

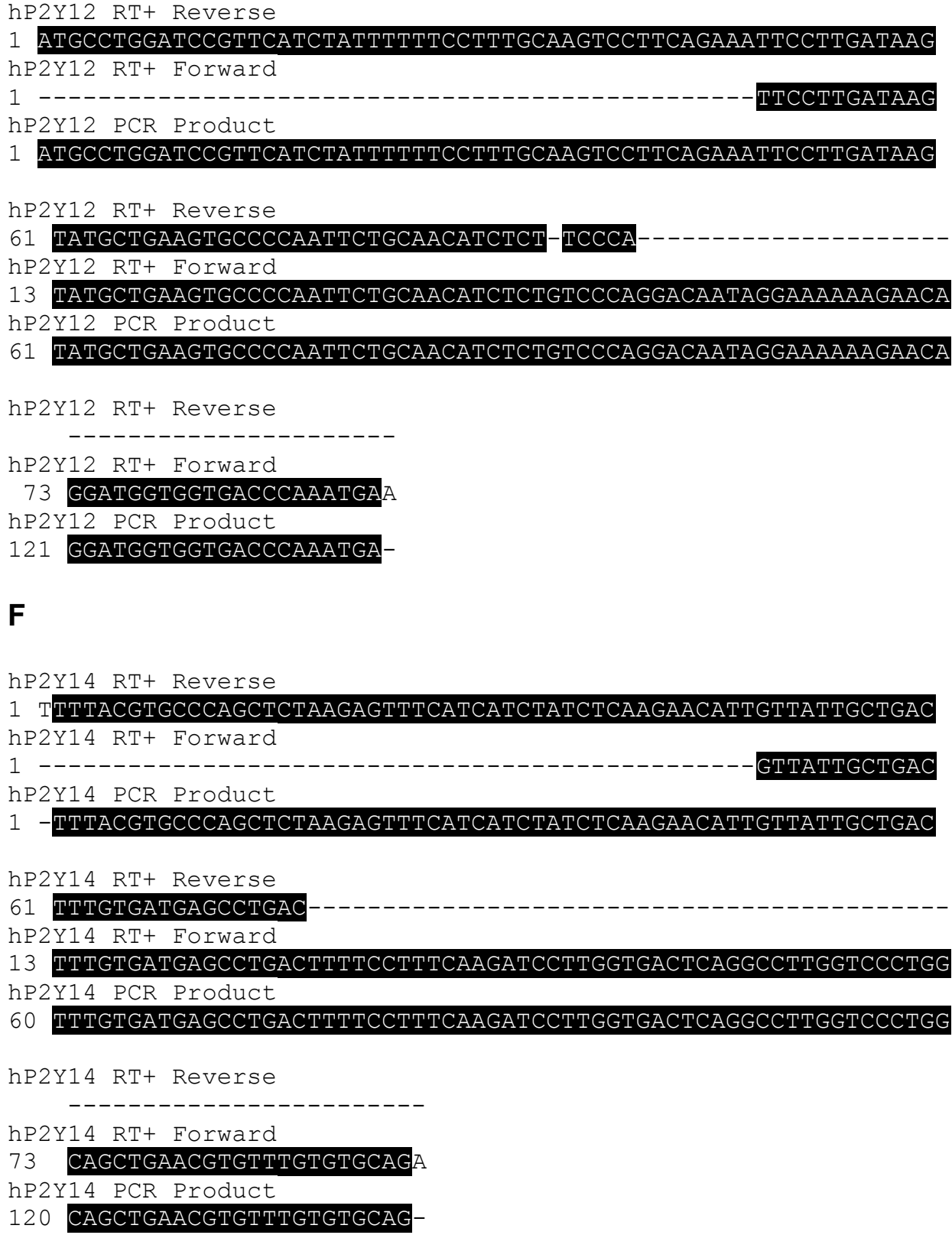

Figure 7: Alignments of the forward and reverse reads for the Sanger sequenced RT+ bands with the expected PCR products nucleotide sequences.

To confirm the identity of the expressed RT+ gel bands they were excised, purified and Sanger sequenced by GATC Biotech. The forward and reverse read sequences were then aligned with one another and the expected PCR product sequences with MUSCLE and processed with Boxshade Server to highlight similarity between the sequences. (A)hP2Y1

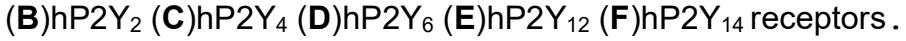




\subsubsection{The RT- Gel Bands Sequences Matched with those of the Expected PCR Products}

The sequenced $\mathrm{hP} 2 \mathrm{Y}_{1}$ receptor $\mathrm{RT}$ - bands (Figure $8 \mathrm{~A}$ ) matched with that of $\mathrm{hP} 2 \mathrm{Y}_{1}$ receptor mRNA (accession NM_002563.4) with 96\% sequence identity in the forward read and 98\% in the reverse read; in both cases this was due to several missing bases. Alignment of the sequences with each other and the expected PCR product was generally complementary aside from several missing and changed bases.

Sequencing the $\mathrm{hP} 2 \mathrm{Y}_{2}$ receptor $\mathrm{RT}$ - bands (Figure $8 \mathrm{~B}$ ) revealed both reads to correspond to all three transcript variants (accession numbers NM_176072.2, NM_176071.2 and NM_002564.3) of $\mathrm{hP2} \mathrm{Y}_{2}$ receptor mRNA with 100\% sequence identity. Likewise, the $\mathrm{hP} 2 \mathrm{Y}_{12}$ receptor RT- band sequence (Figure $8 \mathrm{C}$ ) matched with both transcript variants of hP2 12 receptor mRNA (accession numbers NM_176876.2 and NM_022788.4 with 100\% sequence identity for both read directions. For both receptors the forward and reverse read sequences aligned and matched with their expected PCR product with no differences.

As with the $\mathrm{RT}+$ product, the reverse read of the $\mathrm{hP} 2 \mathrm{Y}_{2}$ receptor $\mathrm{RT}$ - product also matched with 8 transcript variants of $h P 2 Y_{6}$ receptor mRNA (see section 3.2.2), although with $85 \%$ sequence identity compared to $65 \%$ with the RT+. The hP2Y 4 and hP2Y 14 receptors RTbands were not sequenced due to their typically extreme faintness and very inconsistent appearance. 


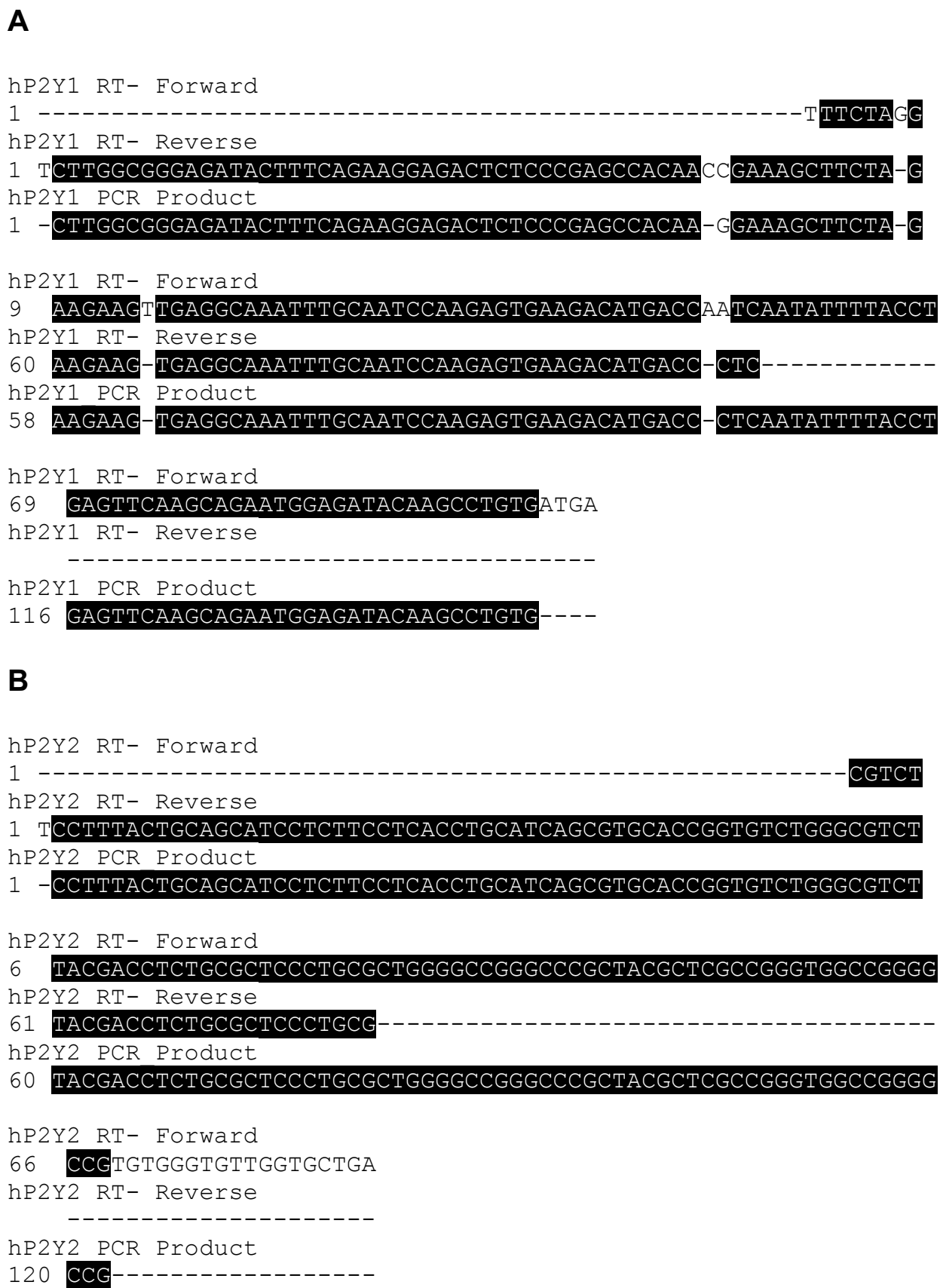




\section{C}

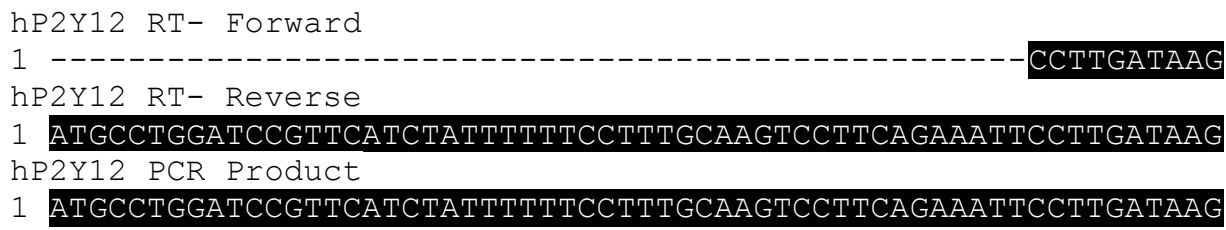

Figure 8: Alignments of the forward and reverse reads for the Sanger sequenced RT- bands with the primers resulting PCR products sequences.

To ascertain the identity of the expressed RT-gel bands they were excised, purified and Sanger sequenced by GATC Biotech. The forward and reverse read sequences were then aligned with one another and the sequence of the PCR product amplified by the primers using MUSCLE, and processed with Boxshade Server to highlight similarity between the sequences. (A)hP2 $\mathrm{Y}_{1}(\mathbf{B}) \mathrm{hP} 2 \mathrm{Y}_{2}(\mathbf{C}) \mathrm{hP} 2 \mathrm{Y}_{12}$ receptors. 


\subsubsection{FlexStation $3 \mathrm{Ca}^{2+}$ Flux Imaging of Wild Type tsA201 Cells with Natural hP2Y Agonists}

Whilst the previous section reports the expression of mRNA for the hP2Y receptor subtypes in the tsA201 cell line, the next experiment examined functional expression of the receptors using $\mathrm{Ca}^{2+}$ flux as a marker. Of the 4 natural $\mathrm{hP} 2 \mathrm{Y}$ agonists (ADP, ATP, UDP, UTP) tested on the same 96 well plate of wild type tsA201 cells (Figures 9A-E), all evoked a concentration-dependent rise in fluorescence signal, indicating the release of $\mathrm{Ca}^{2+}$.

ADP (Figure 9A) was associated with an initial response at $100 \mathrm{nM}$ and then a steady increase until starting to plateau after $10 \mu \mathrm{M}$ and peaking with $100 \mu \mathrm{M}$ ADP. The $\mathrm{pEC}_{50}$ was calculated as $6.32\left( \pm 0.04\right.$ SEM) with the fitted Hill slope as $1.22\left( \pm 0.10\right.$ SEM) and the $E_{\max }$ as $105.90 \%$ ( \pm 1.80 SEM) of the response to $10 \mu \mathrm{M}$ ADP

ATP (Figure 9B) had no appreciable effect up until $1 \mu \mathrm{M}$ where there was a sharp increase in response. The response subsequently peaked at $100 \%$ at $10 \mu \mathrm{M}$ and afterwards there was a steady decrease with increasing ATP concentrations. The calculated $\mathrm{pEC}_{50}$ was $6.04( \pm 0.01$ SEM) with a Hill slope of 1.94 ( \pm 0.33 SEM) and an $E_{\max }$ of $100.90 \%( \pm 1.24$ SEM) of the response to $10 \mu \mathrm{M}$ ATP.

UDP (Figure 9C) did not cause any response until $100 \mu \mathrm{M}$ where there was a small increase in $\mathrm{Ca}^{2+}$ signal. There was then a much more rapid rise with $1 \mathrm{mM}$ UDP, but this was not sustained and the response fell at the top $10 \mathrm{mM}$ concentration. Unfortunately, there were insufficient points in order to effectively fit a response curve.

UTP (Figure 9D) had no visible effect up until $1 \mu \mathrm{M}$, where there was a then a sharp rise in response before beginning to plateau at $100 \mu \mathrm{M}$, peaking at $1 \mathrm{mM}$ and falling at $10 \mathrm{mM}$. There was a pEC50 of $4.93\left( \pm 0.10\right.$ SEM) with a Hill slope of $0.97\left( \pm 0.19\right.$ SEM) and an $E_{\max }$ of $99.94 \%$ ( \pm 4.77 SEM) of the response to $1 \mathrm{mM}$ UTP.

When the averaged raw data for the 96 well plate was plotted as a percentage of the average response to that of $1 \mathrm{mM}$ UTP (Figure 9E), the largest fitted $E_{\max }$ was that of UTP with $100.10 \%( \pm 2.29$ SEM) followed by ADP at $82.44 \%( \pm 1.40$ SEM), ATP with $74.71 \%$ $( \pm 0.63$ SEM) and lastly UDP at approximately $29.54 \%$. 
A

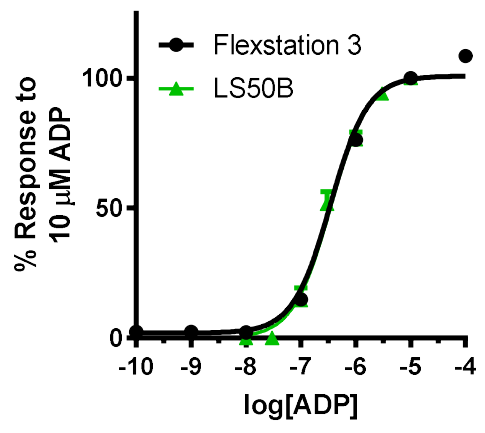

C

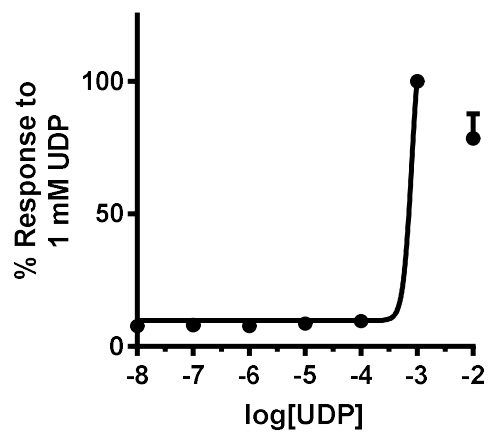

E

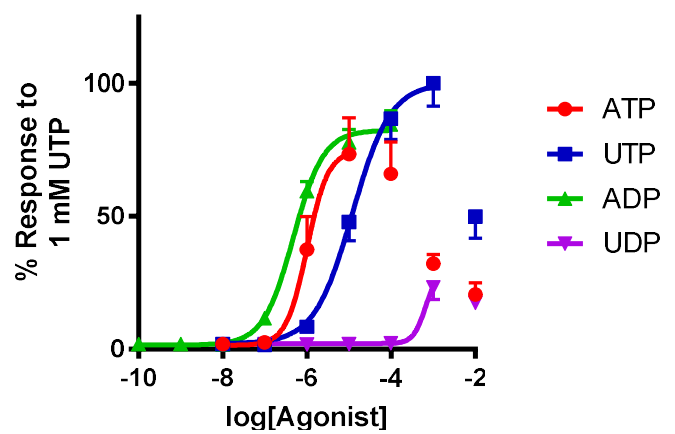

Figure 9: The effects of natural $\mathrm{P} 2 \mathrm{Y}$ receptor agonists on $\mathrm{Ca}^{2+}$ flux signal in wild type tsA201 cells.

Wild type tsA201 cells grown in a 96 well plate and incubated with $5 \mu \mathrm{M}$ Cal-520 AM fluorescent dye for 1.5 hours were stimulated with various concentrations of (A) ADP, a single read (B) ATP, note the -6 point only is a duplicate read (C) UDP and (D) UTP, using the automated dispensing system of a Molecular Devices FlexStation 3 robotic platereader, for triplicate reads except where noted and as further detailed in the text. Responses are expressed as a percentage of the response to $10 \mu \mathrm{M}$ of the agonist, except for UTP and UDP where they are a percentage of the response to $1 \mathrm{mM}$ of each due to the small or absent responses to $10 \mu \mathrm{M}$; the data was then fitted with the Hill equation in GraphPad Prism 7 with the bottom constrained to the average response to buffer only. (A) additionally superimposes the average response curve $(n=4)$ to ADP produced by the LS-50B luminance/spectrophotomer as a comparison.

(E) Plots the signals on the 96 well plate on the same graph, expressed as a percentage of the average response to $1 \mathrm{mM}$ UTP so allow comparison of the fitted $E_{\max }$ values. All error bars in this figure indicate SEM. 
3.3.0 Confirmation of Functional Tagged Receptor Expression using $\mathrm{Ca}^{2+}$ Flux Bioassay

The experiments detailed so far characterised the native expression of hP2Y receptor subtypes in the tsA201 cell line, the other aim of this project however was to biochemically study the interactions between co-expressed recombinant $h P 2 Y_{1}$ and $h P 2 Y_{12}$ receptors. Previous experiments in the Kennedy lab group used $h P 2 Y_{1}$ and $h P 2 Y_{12}$ receptors tagged with both a HA and an FP tag, which would be unsuitable for use in co-immunoprecipitation experiments. Therefore, prior to the start of the project a new set of recombinant receptors expressing a single HA (N-terminus) or C-terminus CFP/YFP tag (HA-hP2 $\mathrm{Y}_{1}, \mathrm{HA}-\mathrm{hP} 2 \mathrm{Y}_{12}$, $\mathrm{hP}_{2} \mathrm{Y}_{1}-\mathrm{YFP}, \mathrm{hP} 2 \mathrm{Y}_{12}$-CFP receptors) were designed, and in the next set of experiments it was tested as to whether they could be functionally expressed in the tsA201 cell line using $\mathrm{Ca}^{2+}$ flux as a bioassay.

\subsection{1 $\mathrm{Ca}^{2+}$ Imaging of Wild Type and Tagged hP2Y 1 Receptor Transfected tsA201 Cells Demonstrated Functional Expression of the Constructs}

When WT tsA201 cells $\mathrm{Ca}^{2+}$ responses were imaged with the LS-50B luminance/spectrophotometer - see Figure 10A for a representative trace - there was no response to ADP until $100 \mathrm{nM}$. The average responses rose rapidly with increasing ADP concentrations before starting to plateau at $3 \mu \mathrm{M}$, immediately before the final $10 \mu \mathrm{M}$ concentration (Figure 10D). A pEC50 of 6.49 ( \pm 0.04 SEM) was fitted, with a Hill slope of 1.35 $( \pm 0.14 \mathrm{SEM})$ and an $\mathrm{E}_{\max }$ of $98.77 \%( \pm 2.85 \mathrm{SEM})$.

Comparison of the FlexStation 3 robotic platereader generated ADP concentration-response curve with the averaged WT tsA201 ADP concentration response curve $(n=4)$ produced by the LS-50B luminance/spectrophotometer (see Figure $9 \mathrm{~A}$ ) using the extra sum of squares $\mathrm{F}$ test (ESSFT) did not find any statistically significant differences in the fitted $p E C_{50}$, Hill slope or $E_{\max }$ parameters, and therefore confirmed the two methods as being comparable.

When $1 \mu \mathrm{g}$ of either hP2Y ${ }_{1}$-YFP or HA-hP2 $Y_{1}$ receptor $\mathrm{cDNA}$ was transfected into the cell line and the $\mathrm{Ca}^{2+}$ response measured with the LS-50B - see Figures $10 \mathrm{~B}$ and $10 \mathrm{C}$ for respective representative traces - there was a shift to the left in the concentration-response curve (Figure 10D) compared to the WT cells. The initial 300 pM of ADP produced a small response for each, contrasting with there being no response at the initial $10 \mathrm{nM}$ 
concentration in wild type cells. Compared to the WT only cells, the response curves were shallower for both plasmids, but began to plateau out at similar concentrations.

The fitted $\mathrm{pEC}_{50}$ values for the $\mathrm{HA}-\mathrm{hP} 2 \mathrm{Y}_{1}$ and $\mathrm{hP} 2 \mathrm{Y}_{1}-\mathrm{YFP}$ receptor plasmids were 7.13 $( \pm 0.17$ SEM) and 6.96 ( \pm 0.11 SEM) respectively, which were not significantly different from one another using the ESSFT, although only the HA-hP2Y $\mathrm{pEC}_{50}$ was statistically significant from that of the WT cells ( $p \leq 0.05)$. The Hill slopes were respectively $0.40( \pm 0.04 \mathrm{SEM})$ and 0.49 ( \pm 0.04 SEM), which were not significantly different, but both were significant from the Hill slope of the WT cells ( $p \leq 0.001$ ). The plasmids fitted $E_{\max }$ values were not significantly altered from one another, but only the HA-hP2Y 1 receptors $E_{\max }$ of $114.90 \%( \pm 6.25$ SEM) of the response to $10 \mu \mathrm{M}$ ADP was statistically significant from the wild type cells $(p \leq 0.05)$. This overall suggests that both of the tagged $\mathrm{hP}_{2} \mathrm{Y}_{1}$ receptors were functionally expressed in the tsA201 cells following transfection. 

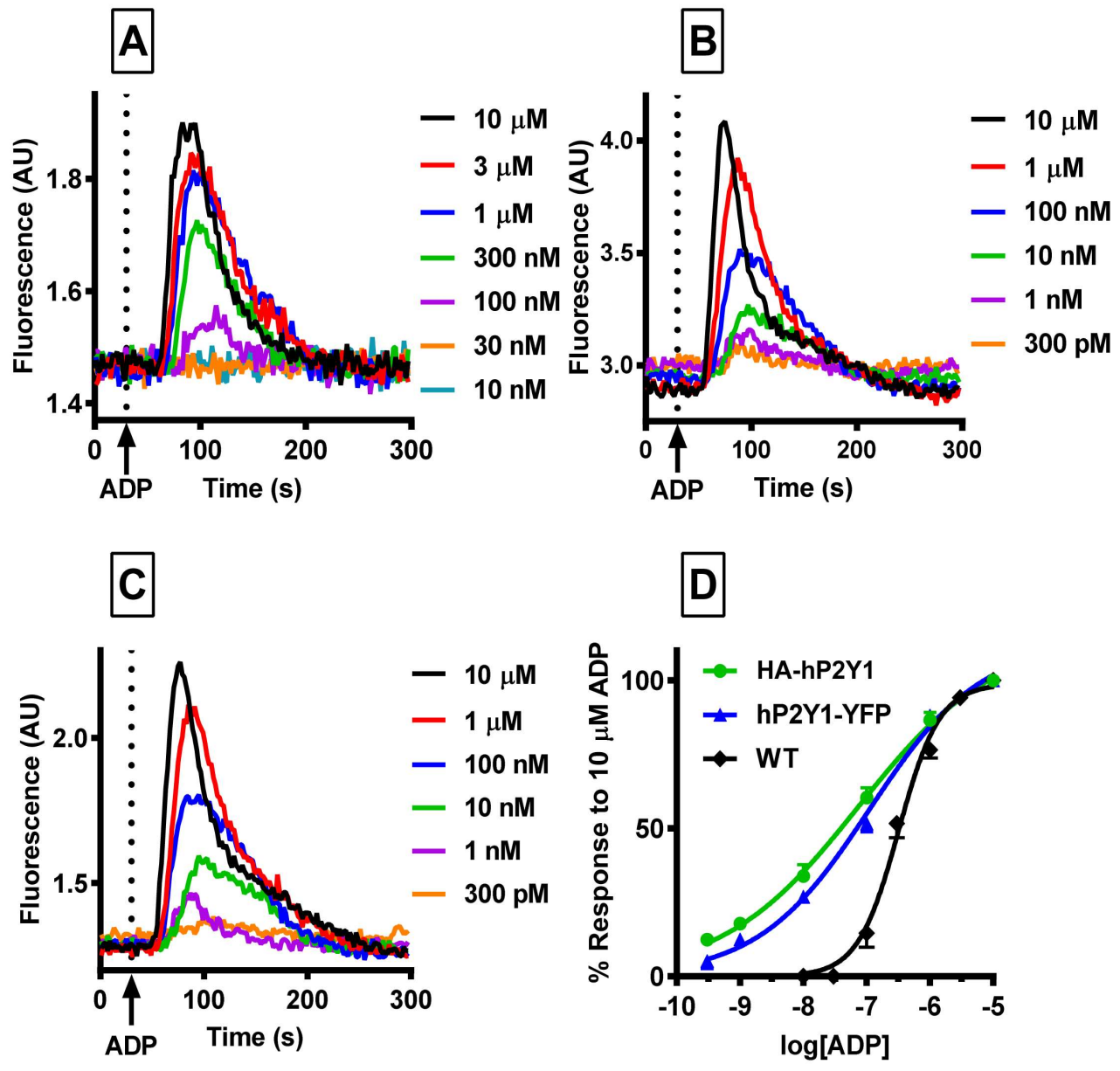

Figure 10: The effect of ADP stimulation on intracellular $\mathrm{Ca}^{2+}$ signalling in wild type tsA201 cells and when transfected with hP2Y ${ }_{1}$-YFP or HA-hP2Y 1 receptor cDNA.

The $\mathrm{Ca}^{2+}$ flux of coverslips of tsA201 cells was assayed on an LS-50B luminance/spectrophotometer using Cal-520 AM fluorescent $\mathrm{Ca}^{2+}$ dye. Representative $\mathrm{Ca}^{2+}$ traces of un-transfected wild type (WT) cells (A) and cells expressing $\mathrm{hP}_{2} \mathrm{Y}_{1}-\mathrm{YFP}$ receptors (B) or HA-hP2Y 1 receptors (C) are shown. Cells were subjected to different concentrations of ADP stimulation (at the arrow point) until the response peaked; these are representative of at least 3 independent experiments each. (D) Concentration-response curves were generated and graphically present the averaged responses to the concentrations of ADP on the cells ( $n=3$ for $h P 2 Y_{1}$-YFP receptors, $n=4$ for WT and $n=5$ for $h P 2 Y_{1}-H A$ receptors) and fitted with the Hill equation in GraphPad Prism 7. Error bars indicate SEM. 


\subsection{2 $\mathrm{Ca}^{2+}$ Imaging Established that the Tagged $\mathrm{hP}^{2} \mathrm{Y}_{12}$ Receptors could be Functionally Expressed in the ts A201 Cell Line}

$h P 2 Y_{12}$ receptors couple to the $G_{i / o}$ subunit and therefore when activated do not directly mediate any increase in $\mathrm{Ca}^{2+}$ flux (Abbracchio et al., 2006). Consistent with this the ADP evoked release of intracellular $\mathrm{Ca}^{2+}$ is not inhibited by the selective $h P 2 Y_{12}$ receptor antagonist cangrelor in wild type tsA201 cells, but is abolished by the selective hP2Y, receptor antagonist MRS2179. When recombinant $\mathrm{hP}_{2} \mathrm{Y}_{12}$ receptors are overexpressed in the tsA201 cell line though, the $\mathrm{Ca}^{2+}$ response becomes sensitive to cangrelor and is also abolished by MRS2179 (Naughton et al., 2014); this data forms the core of the hypothesis by Naughton (2014) that $\mathrm{hP}_{2} \mathrm{Y}_{1}$ and $\mathrm{hP} 2 \mathrm{Y}_{12}$ receptors can form a functional heterodimer. Consequently, in the next set of experiments it was aimed to determine the functional expression of tagged $\mathrm{hP}_{2} \mathrm{Y}_{12}$ receptors transfected into the tsA201 cell line, using the inhibition by cangrelor of ADP-induced intracellular $\mathrm{Ca}^{2+}$ release as a bioassay.

For either of the $\mathrm{hP}_{2} \mathrm{Y}_{12}-\mathrm{CFP}$ or HA-hP2 $\mathrm{Y}_{12}$ receptor plasmids transfected $(1 \mu \mathrm{g})$ into the tsA201 cell line, the repeated 3 or 4 additions of 300 nM ADP did not cause any visible appreciable change in response and linear regression analysis did not find any slopes statistically significant from zero (data not shown); see figures $11 \mathrm{~A}$ and $11 \mathrm{C}$ for representative $\mathrm{hP} 2 \mathrm{Y}_{12}-\mathrm{CFP}$ and $\mathrm{HA}-\mathrm{hP} 2 \mathrm{Y}_{12}$ receptor traces of the repeated $\mathrm{ADP}$ additions.

As further illustrated in Figures 11B, D and E, $1 \mu \mathrm{M}$ cangrelor by itself caused no change in fluorescence signal, but the average responses to $300 \mathrm{nM}$ ADP were reduced by $68.0 \%$ $( \pm 6.6$ SEM, $n=5)$ and $67.8 \%( \pm 5.3 \mathrm{SEM}, \mathrm{n}=5)$ in the presence of $1 \mu \mathrm{M}$ cangrelor for the $\mathrm{hP} 2 \mathrm{Y}_{12}$-CFP and HA-hP2Y 12 receptor plasmids correspondingly. Following 5 minutes of washout to remove the cangrelor, the mean responses of hP2 $\mathrm{Y}_{12}-\mathrm{CFP}$ and HA-hP2 12 receptors to $300 \mathrm{nM}$ ADP were not significantly different from before the addition of cangrelor, but were significantly greater than in its presence $(p \leq 0.0001$ and $p \leq 0.001$ respectively). The plasmids showed no overall statistically significant differences in response between each other. As the $\mathrm{Ca}^{2+}$ responses were supressed by the presence of the selective $\mathrm{P} 2 \mathrm{Y}_{12}$ antagonist cangrelor, it suggested that the tagged $\mathrm{hP} 2 \mathrm{Y}_{12}$ receptors had been functionally expressed in the cell line. 

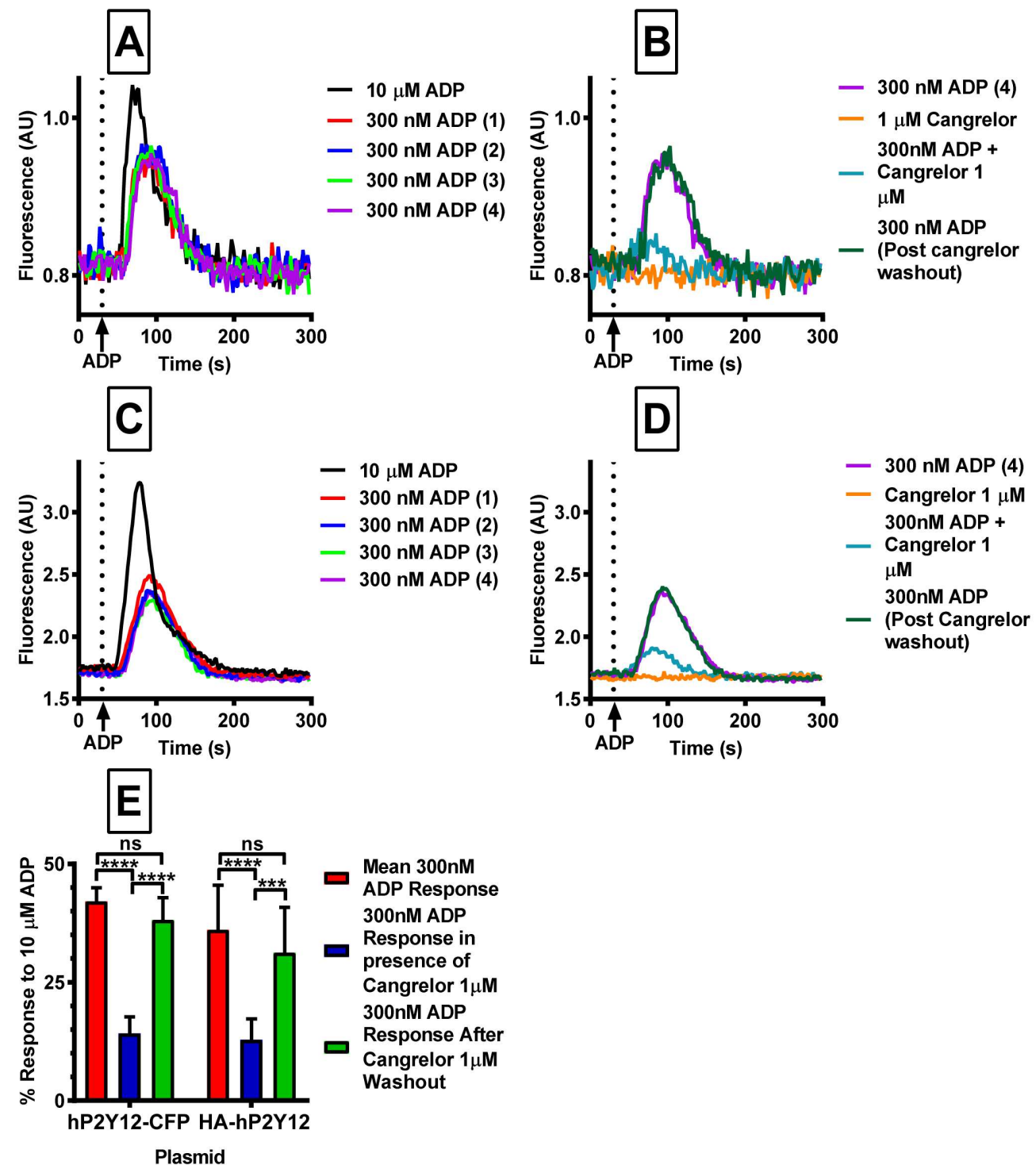

Figure 11: The effect of ADP stimulation on intracellular $\mathrm{Ca}^{2+}$ after transfecting $\mathrm{hP} 2 \mathrm{Y}_{12-}$ CFP or HA-hP2Y 12 receptor cDNA into the tsA201 cell line.

$1 \mu \mathrm{g}$ of hP2 $\mathrm{Y}_{12}-\mathrm{CFP}$ or hP2Y $\mathrm{Y}_{12}-\mathrm{HA}$ containing plasmid was transfected into tsA201 cells on coverslips and imaged on an LS-50B luminance/spectrophotometer using Cal-520 AM fluorescent $\mathrm{Ca}^{2+}$ dye. Representative $\mathrm{Ca}^{2+}$ traces are shown for $(\mathbf{A})$ hP2Y $12-\mathrm{CFP}$ and (C) HA-hP2Y 12 transfected cells when subjected to repeated $300 \mathrm{nM}$ ADP control stimulations (at the arrow point). (B) hP2 $\mathrm{Y}_{12}$-CFP and (D) HA-hP2 $\mathrm{Y}_{12}$ show the traces for the last $300 \mathrm{nM}$ ADP control stimulation, and subsequently those for the response to the $1 \mu \mathrm{M}$ of the $\mathrm{P}_{2} \mathrm{Y}_{12}$ receptor antagonist cangrelor alone, the response to $300 \mathrm{nM}$ ADP in the presence of $1 \mu \mathrm{M}$ cangrelor and the response to $300 \mathrm{nM}$ ADP after 5 minutes of washout. These two sets of traces are each representative of 5 independent experiments.

(E) Graphically presents the averaged responses from the $\mathrm{Ca}^{2+}$ traces for each plasmid $(n=5$ each) as a percentage of the initial $10 \mu M$ ADP concentration, error bars represent SEM; the plasmids were not overall statistically different from one another. ${ }^{* * *}=p \leq 0.001$ $* * * *=p \leq 0.0001 \mathrm{~ns}=$ not significant. 


\subsubsection{Co-immunoprecipitation and Western Blotting}

The previous set of experiments confirmed that HA or FP tagged $h P 2 Y_{1}$ and $h P 2 Y_{12}$ receptors were functionally expressed when transfected into the tsA201 cells. The final set of experiments therefore aimed to investigate whether they would co-immunoprecipitate when expressed together, after first determining whether the singular HA or FP tagged receptors themselves could be immunoprecipitated.

\subsubsection{GFP-Immunoprecipitation and Blotting Showed that Individual FP Tagged Receptors could be Immunoprecipitated}

Following transfection of tsA201 cells with $2.5 \mu \mathrm{g}$ of GFP, P2Y 1 -YFP or P2 $\mathrm{Y}_{12}$-CFP and immunoprecipitating for GFP, probing with anti-GFP revealed no signal in the no-cDNA untransfected control lanes for either the inputs or for the IP samples (Figure 12A). In all transfected lanes there was prominent signal at $\sim 27 \mathrm{KDa}$ visible in both the inputs and IP samples, corresponding to the GFP; this was substantially stronger in the IP lanes. The hP2 $Y_{1}$-YFP receptor IP sample presented as a "smear" signal from $\sim 40$ to $>250 \mathrm{KDa}$ (based on the pre-stained protein standards), with the band at $\sim 70 \mathrm{KDa}$ likely representing the hP2Y ${ }_{1}$-YFP receptor (predicted molecular weight $69.0 \mathrm{KDa}$ ), and other bands posttranslationally modified forms of the receptor such as homodimers or those undergone glycosylation. The hP2 $\mathrm{Y}_{12}$-CFP receptor IP sample presented as clearly defined bands with the band at $\sim 65 \mathrm{kDa}$ probably representing the CFP tagged $\mathrm{hP}_{2} \mathrm{Y}_{12}$ receptor (predicted molecular weight $66.3 \mathrm{KDa}$ ) and the other bands post-translational modifications of the receptor as with the hP2Y ${ }_{12}$-YFP. These signals typically did not show clearly in the input samples, and by being visible in the IP samples overall suggested that the FP tagged complexes had been successfully immunoprecipitated from the other proteins present in the inputs and exposed the epitope.

\subsubsection{HA-Immunoprecipitation and Blotting Demonstrated Successful Immunoprecipitation of Individually Expressed HA Tagged Receptors}

After transfecting tsA201 cells with $2.5 \mu \mathrm{g}$ of $\mathrm{HA}$ tagged $\mathrm{hP} 2 \mathrm{Y}_{1}$ or $\mathrm{P}_{2} \mathrm{Y}_{12}$ receptor and immunoprecipitating for the HA tag, probing with anti-HA showed no signal in the untransfected no-cDNA control lanes for the inputs or IP samples (Figure 12B); although prominent bands were visible in the HA-peptide control lanes these corresponded to the light 
and heavy IgG chains of the beads. The HA-hP2Y, receptor IP lane presented as a "smear" ranging from $\sim 30$ to $250 \mathrm{KDa}$ (based on the pre-stained protein standards), with the band at $\sim 40 \mathrm{KDa}$ probably representing the HA-hP2Y 1 receptor (predicted molecular weight 43.2 $\mathrm{KDa}$ ) and the other bands post-translational modifications of the receptor; the signal strength was substantially stronger in the IP sample compared to the input. The HA-hP2 $Y_{12}$ IP lane also presented as a "smear", but from $\sim 36$ to $55 \mathrm{KDa}$ with the band at $\sim 40 \mathrm{KDa}$ likely representing the $\mathrm{HA}-\mathrm{hP} 2 \mathrm{Y}_{12}$ receptor (predicted molecular weight $40.5 \mathrm{KDa}$ ); these were barely detectable in the input sample. The presence of "smear" signals in the HA-peptide controls similar to those of the IP samples suggested that the some of the bound proteins had not been competed off the beads by the peptide, however using either $6 \mu \mathrm{g}$ or $16 \mu \mathrm{g}$ of HA-peptide did not appear to alter the result (data not shown) appreciably so $8 \mu \mathrm{g}$ was used to elute in future experimentations. As a whole the HA tagged complexes appeared to have been successfully immunoprecipitated. 


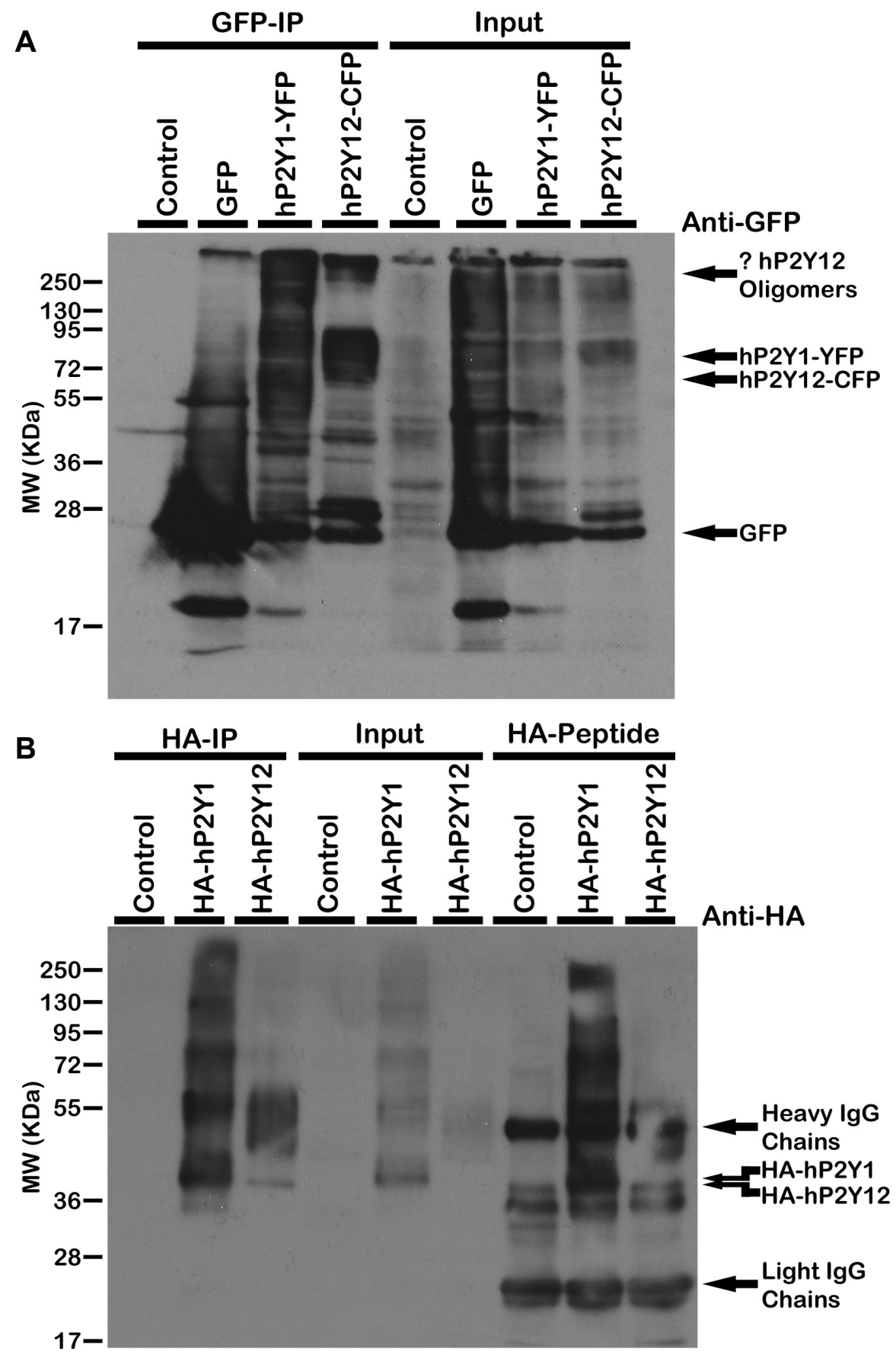

Figure 12: Immunoprecipitation of singular FP tagged and $\mathrm{HA}$ tagged $\mathrm{hP} 2 \mathrm{Y}_{1}$ and hP2 $\mathrm{Y}_{12}$ receptors.

tsA201 cells were transfected with (A) fluorescent protein (FP) tagged constructs of $h \mathrm{~h}_{2} \mathrm{Y}_{1}$ or $\mathrm{hP} 2 \mathrm{Y}_{12}$ receptors and $(\mathrm{B}) \mathrm{HA}$ tagged $\mathrm{hP} 2 \mathrm{Y}_{1}$ or $\mathrm{hP} 2 \mathrm{Y}_{12}$ receptors, along with a control lane containing no transfected cDNA. The cells were lysed and denatured to provide crude whole cell lysates as input samples, then immunoprecipitated for GFP for the FP tagged receptors and HA for the HA tagged receptors; the HA samples have a further set of "HA-peptide" lanes representing immunoprecipitated proteins not competed off of the beads. The respective protein tag was then blotted for. The HA immunoprecipitation is representative of 2 independent experiments whilst the GFP IP represents a single experiment. 


\subsubsection{HA-Immunoprecipitation of Differentially Tagged Co-expressed $\mathrm{hP}_{2} \mathrm{Y}_{1}$ and hP2Y 12 Receptors and Blotting with Anti-GFP Demonstrated a High Molecular Weight Protein Complex}

Based on the results of the individual immunoprecipitations it was decided to immunoprecipitate for the HA tag as it gave a clearer signal, and then determine if the FP tag was co-immunoprecipitated. Samples were prepared with $2.5 \mu \mathrm{g}$ each of a HA-hP2Y ${ }_{1}$ or HA$h P 2 Y_{12}$ receptor and the correspondingly opposite hP2 $\mathrm{Y}_{12}-\mathrm{CFP}$ or $\mathrm{hP} 2 \mathrm{Y}_{1}$-YFP receptor cotransfected together. Samples were also prepared of each HA tagged receptor cotransfected with $2.5 \mu \mathrm{g}$ GFP to detect any non-specific precipitation of the GFP. The samples were immunoprecipitated for the HA tag and then blotted for the FP tag to determine if the FP tagged receptor were precipitated along with the HA tagged receptor (Figure 13A).

No signals presented in the un-transfected no-cDNA control lane for the inputs or IP samples, and likewise no signals were visible in any of the IP lanes transfected with a HA tagged receptor and GFP. This suggested that the GFP alone did not immunoprecipitate with the receptors, but that it had successfully transfected as evidenced by the band at $\sim 27 \mathrm{KDa}$ in the input lanes. In both of the co-transfected receptor IP lanes a high molecular weight complex of $\sim 130$ to $>250 \mathrm{KDa}$ (based on the pre-stained protein standards) was detected, with the signal strength in the HA-hP2 $\mathrm{Y}_{12}+\mathrm{hP} 2 \mathrm{Y}_{1}$-YFP receptors IP lane being stronger and additionally visible in the input lane. After stripping and blotting with anti-HA this higher weight complex was again visible (Figure 13B), although more faintly, as were bands at $\sim 45$ $\mathrm{KDa}$ and $\sim 40 \mathrm{KDa}$ in the respective lanes, which likely corresponded to the monomeric $\mathrm{HA}$ tagged $\mathrm{hP} 2 \mathrm{Y}_{1}$ and $\mathrm{hP} 2 \mathrm{Y}_{12}$ receptors. Interestingly co-expression of the two receptors appeared to reduce the signal strength compared to the singular HA tagged receptors coexpressed with GFP.

After re-running the samples (due to stripping difficulties where the higher affinity anti-HA could not be removed - detailed in section 2.4.3) and blotting with anti- $\beta$-tubulin there was a strong band expressed across all of the input lanes at $55 \mathrm{KDa}$, which did not present in the IP lanes (Figure 13C). The membrane was stripped and anti-HA blotted with again (using a lower 1:10000 concentration due the intense staining at 1:5000) to determine if the membrane was representative of the first; identical results presented aside from the higher molecular weight complexes being slightly more visible (Figure 13D). This is unfortunately only representative of a single co-IP experiment however due to insufficient time being available for further repeats. 


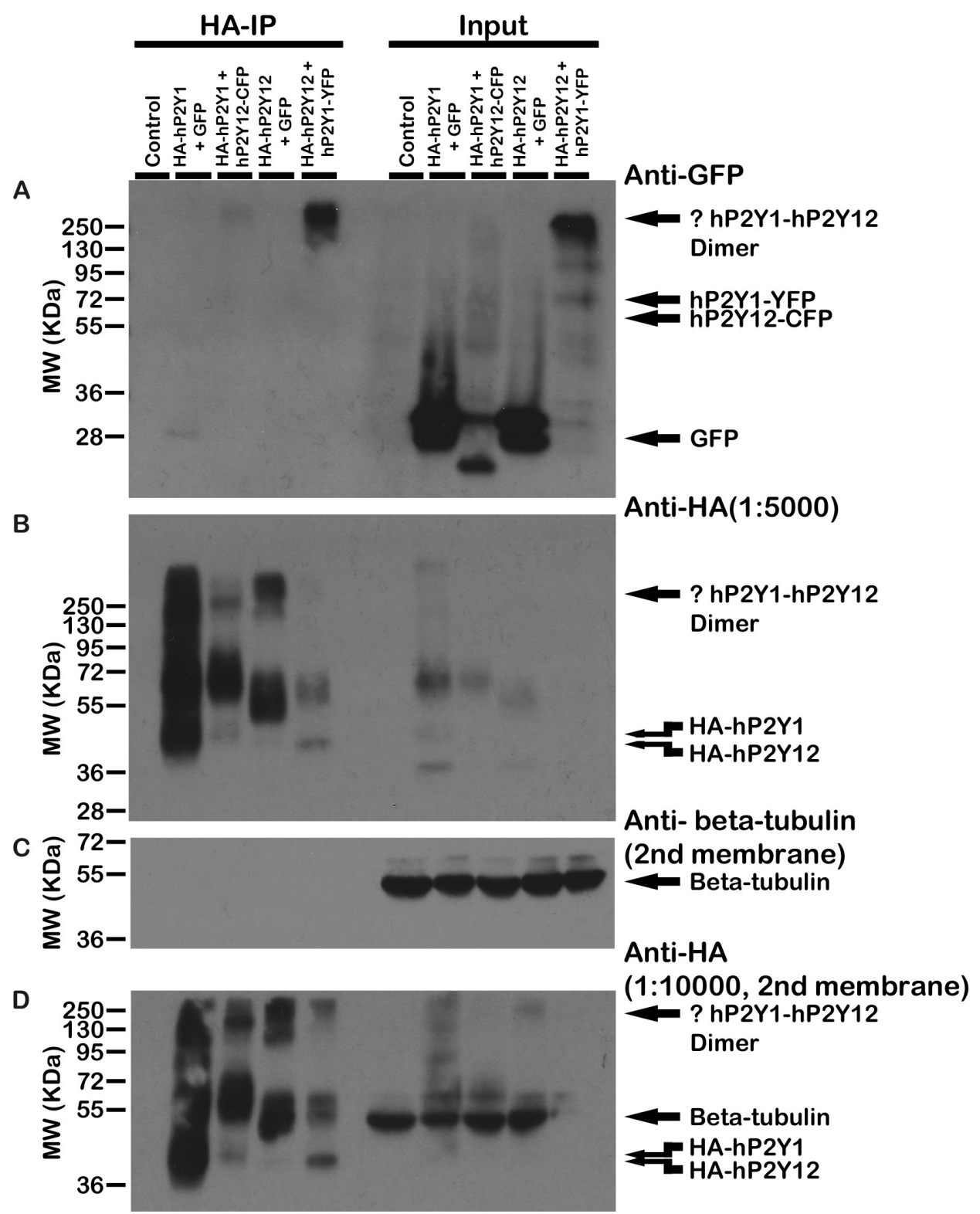

Figure 13: HA co-IP of co-expressed tagged $\mathrm{hP}_{2} \mathrm{Y}_{1}$ and $\mathrm{hP}_{2} \mathrm{Y}_{12}$ receptors in tsA201 cells

tsA201 cells were co-transfected with a HA tagged form of $h P 2 \mathrm{Y}_{1}$ or $\mathrm{hP} 2 \mathrm{Y}_{12}$ and an FP tagged construct of the opposing receptor; other samples had no cDNA transfected (control) or had $\mathrm{HA}$ tagged $\mathrm{hP}_{2} \mathrm{Y}_{1}$ or $\mathrm{hP}_{2} \mathrm{Y}_{12}$ receptor cDNA plus separate GFP $\mathrm{cDNA}$ transfected. These were lysed and denatured to provide crude "input" samples before being immunoprecipitated for the HA tag to purify. The FP tag was then blotted for with anti-GFP to detect any physical association of the HA tagged and FP tagged receptors following the immunoprecipitation (A). After stripping the membrane was re-probed with anti-HA to confirm that the HA tagged receptors were present in the IP samples (B). The samples were re-run on a separate gel and the membrane then blotted for the loading control anti- $\beta$-tubulin to confirm that protein was present (C). Following stripping this second membrane was re-probed with anti-HA to ensure that the results between the two membranes were complementary - note that the $\beta$-tubulin staining remains as it did not strip fully (D). This panel is representative of a single experiment. 
Chapter 4: Discussion and Conclusions 


\subsubsection{Endogenous hP2Y Receptor Expression in the tsA201 cell line}

As the overall expression of $\mathrm{hP2Y}$ receptor subtypes present in the tsA201 cell line is relatively unknown, qualitative RT-PCR and Sanger sequencing were used to characterise individual receptor mRNA expression: this demonstrated the presence of mRNA for $h P 2 Y_{1}, 2$, 4, 6, 12, 14 receptors. $\mathrm{Ca}^{2+}$ flux imaging was also used to try to ascertain functional hP2Y receptor expression, which demonstrated concentration dependent responses to all 4 of the natural P2Y agonists tested, these being ADP, ATP, UDP and UTP.

The tsA201 cell line is an SV40 transformed derivative of the HEK-293 cell line stably expressing the large-T antigen to improve plasmid copy number and protein expression (Mellon et al., 1981). Previous whole genome sequencing of the HEK-293 cell line and related derivatives (including the similarly SV40 transformed HEK-293T line) has revealed them to be typically complementary in expression of most genes, including expressing mRNA sequences for all of the hP2Y receptors (Lin et al., 2014), but many individual studies have found differing results using complementary techniques as will be further detailed.

The presence of $\mathrm{P}_{2} \mathrm{Y}_{1}$ mRNA in this study is consistent with previous reports in HEK-293 cells and derived cell lines (Schachter et al., 1997; Moore et al., 2001; Fischer et al., 2003; Wirkner et al., 2004; Atwood et al., 2011). Functional hP2Y 1 receptor expression in the tsA201 cell line is strongly suggested from the concentration dependent increases in $\mathrm{Ca}^{2+}$ signal upon ADP stimulation in this project, and from past work in the Kennedy lab where the responses to ADP continued in the presence of the antagonist cangrelor, which inhibits ADP sensitive $h P 2 Y_{12},{ }_{13}$ receptors, but were abolished by the selective $\mathrm{P} 2 \mathrm{Y}_{1}$ receptor antagonist MRS2179 (Naughton et al., 2014). This has been observed in other HEK-293 derived cell lines (Suzuki et al., 2011), with similar $\mathrm{pEC}_{50}$ values for ADP also reported (Mundell and Benovic, 2000; Werry et al., 2002). In addition, Western blotting and immunocytochemical staining have demonstrated $\mathrm{hP} 2 \mathrm{Y}_{1}$ protein expression in HEK-293 cell lines (Fischer et al., 2003; Wirkner et al., 2004).

As ADP also acts on the $\mathrm{hP}_{2} \mathrm{Y}_{12}$ and $\mathrm{hP} 2 \mathrm{Y}_{13}$ receptors there is the possibility of expression of these in the tsA201 cell line: this is supported by the presence of $h P 2 Y_{12}$ receptor mRNA in this project, but PCR products for $\mathrm{hP}_{2} \mathrm{Y}_{13}$ receptor mRNA were absent. Although both receptors are $\mathrm{G}_{\mathrm{i} / \mathrm{o}}$ linked and not traditionally associated with signalling through $\mathrm{Ca}^{2+}, \mathrm{hP}_{2} \mathrm{Y}_{12}$ receptors are known to modulate the $\mathrm{Ca}^{2+}$ response induced through the $\mathrm{hP} 2 \mathrm{Y}_{1}$ receptor (Hardy et al., 2004; Suzuki et al., 2011). Data from the Kennedy lab group has previously 
suggested the presence of a low level of functional hP2 $\mathrm{Y}_{12}$ receptors in tsA201 cells, based on how cangrelor can subtly alter the $\mathrm{Ca}^{2+}$ response induced through the $\mathrm{hP} 2 \mathrm{Y}_{1}$ receptor (Naughton, 2014). Analogous conclusions were drawn by Suzuki et al. (2011) in similarly SV40 transformed HEK-293T cells, although cangrelor caused a decrease in $\mathrm{Ca}^{2+}$ signal compared to an increase as described by Naughton (2014), which may be related to the increased concentration used. Inbe et al. (2004) also found $\mathrm{hP} 2 \mathrm{Y}_{12}$ receptor mRNA in HEK293 cells, and contrastingly $\mathrm{hP}_{2} \mathrm{Y}_{13}$ receptor mRNA as well, which is consistent with the whole genome sequencing of HEK-293 cell lines by Lin et al. (2014), where hP2Y 12, 13 receptor mRNA was present in all those sequenced, although at varying expression levels.

The responses to ATP and UTP in the tsA201 cells in this project are overall likely indicative of $\mathrm{hP}_{2} \mathrm{Y}_{2}$ and/or $\mathrm{hP} 2 \mathrm{Y}_{4}$ expression: both of these stained faintly on agarose gels after RTPCR and their identities were confirmed by Sanger sequencing. Whilst ATP also acts as a full agonist on the $G_{q}$ coupled $h P 2 Y_{11}$ receptors, no PCR products were observed in difference to reports in other HEK-293 derived cell lines (Moore et al., 2001; Wirkner et al. 2004). Despite both $\mathrm{hP}_{2} \mathrm{Y}_{2}$ and $\mathrm{hP} 2 \mathrm{Y}_{4}$ receptors responding to UTP, because ATP acts as an antagonist at the $\mathrm{hP}_{2} \mathrm{Y}_{4}$ receptor (Kennedy et al., 2000) any ATP induced $\mathrm{Ca}^{2+}$ responses in the tsA201 cells are likely from $\mathrm{hP} 2 \mathrm{Y}_{2}$ receptor binding due to the lack of $\mathrm{hP} 2 \mathrm{Y}_{11}$ receptor mRNA, although ATP additionally acts as a partial agonist at the $\mathrm{hP} 2 \mathrm{Y}_{1}$ receptor as detailed later. The reduced potencies of ATP and UTP compared to ADP suggests that any hP2 $2 \mathrm{Y}_{2,4}$ receptors are expressed at a lower level compared to ADP sensitive $\mathrm{hP} 2 \mathrm{Y}_{1}$ receptors.

Dickson et al. (2013) have demonstrated UTP sensitivity and a decreased response to UTP in the presence of $100 \mu \mathrm{M}$ suramin in the tsA201 cell line, along with hP2Y 2 protein expression using Western blotting; this was reduced by $\mathrm{hP}_{2} \mathrm{Y}_{2}$ receptor small interfering RNA (siRNA) knockdown. Whilst they also proposed that hP2 $\mathrm{Y}_{11}$ was absent based on the inability of UTP to raise cAMP, UTP has since been found to not act at the hP2 $\mathrm{Y}_{11}$ receptor (Morrow et al., 2014). Mundell and Benovic (2000) have also reported $100 \mu \mathrm{M}$ of ATP or UTP to analogously raise inositol phosphate accumulation in HEK-293 cells, which suggests $\mathrm{hP} 2 \mathrm{Y}_{2}$ and/or $\mathrm{hP}_{2} \mathrm{Y}_{4}$ receptor expression. In other HEK-293 derived cell lines there is much conflicting evidence both suggesting and contesting $\mathrm{hP}_{2} \mathrm{Y}_{2}$ receptor expression (Moore et al., 2001; Schäfer et al., 2003; Wirker et al., 2004).

There is the possibility that the ATP induced $\mathrm{Ca}^{2+}$ responses observed were due to ATP acting exclusively as a partial agonist at the hP2Y, receptor in the tsA201 cells (Palmer et al., 1998; Waldo and Harden, 2004). This is seen as unlikely though because the fitted $E_{\max }$ parameters of the ADP and ATP concentration response curves from the FlexStation 3 were 
very similar, rather than ATP showing the clear sub-maximal response associated with partial agonism. The Hill slope of above unity for ATP could further suggest it acting on multiple targets - it is accepted though that the Hill slope and $E_{\max }$ obtained for the ATP are likely somewhat inaccurate due to there only being a single point in the middle of the curve and few points overall from $0-100 \%$. The additional partial agonist action of ATP at the $\mathrm{hP}_{2} \mathrm{Y}_{1}$ receptor may also perhaps explain the greater $\mathrm{pEC}_{50}$ of ATP compared to UTP as the two are usually seen as equal in potency at the $\mathrm{hP}_{2} \mathrm{Y}_{2}$ receptor (Velázquez et al., 2000). Contrastingly Mundell and Benovic (2000) have reported that in WT HEK-293 cells ADP, ATP and UTP each raised inositol phosphate accumulation by similar levels; although this may be reflective of the different signalling assay used, $\mathrm{Ca}^{2+}$ concentration-response curves for ADP and ATP also revealed them to have very similar $\mathrm{EC}_{50}$ values.

Despite the responses to UTP and the $\mathrm{hP}_{2} \mathrm{Y}_{4}$ receptor mRNA expression in this project, there is unfortunately little prior evidence to directly support or refute $\mathrm{hP}_{2} \mathrm{Y}_{4}$ receptor functional expression specifically in the tsA201 cell line. Similar results have been published for $\mathrm{hP}_{2} \mathrm{Y}_{4}$ mRNA expression in the parent HEK-293 cell line, with Moore et al. (2001) showing $\mathrm{hP}_{2} \mathrm{Y}_{4}$ as having the second highest mRNA expression level of the P2Y receptors characterised and Wirker et al. (2001) finding mRNA, plus also a small number of hP2Y 4 receptors with immunocytochemistry. The UTP concentration-response curve demonstrated a higher $E_{\max }$ compared to ATP when plotted on the same graph, which could indicate both UTP sensitive $\mathrm{hP}_{2} \mathrm{Y}_{2}$ and $\mathrm{hP}_{2} \mathrm{Y}_{4}$ receptors being activated and inducing greater $\mathrm{Ca}^{2+}$ release. Based on the past literature and the findings of this project, it is therefore likely that tsA201 cells express functional $\mathrm{hP}_{2} \mathrm{Y}_{2}$ receptors, but it is unclear as to functional $\mathrm{hP} 2 \mathrm{Y}_{4}$ receptor expression without further study.

$\mathrm{hP}_{2} \mathrm{Y}_{6}$ and $\mathrm{hP}_{2} \mathrm{Y}_{14}$ receptor mRNA were detected in the tsA201 cell line in this project. This corresponds with the previous whole genome sequencing by Lin et al., (2014) in the HEK293 cell line and derivatives; other studies have found hP2Y 6 receptor (Wirker et al., 2001) or hP2Y $_{14}$ receptor (Moore et al., 2003) mRNA, but Schäfer et al. (2003) and Moore et al. (2001) did not find evidence of $\mathrm{hP}_{2} \mathrm{Y}_{6}$ receptor mRNA (hP2Y 14 receptor mRNA was not searched for in these studies). As a small response was found to high $(\geq 1 \mathrm{mM})$ concentrations of UDP in this project it suggests a low level of functional expression of either or both types of receptor as they uniquely respond to UDP out of the hP2Y receptors. It is unfortunately not possible to differentiate between the two though with the present data due to the lack of any insights on the response to UDP-glucose, which only acts on the hP2 $\mathrm{Y}_{14}$ receptor. 
Despite initial reports suggesting a competitive antagonist action of UDP on the hP2Y 14 receptor (Fricks et al., 2008), later assays have confirmed its action as an agonist at the $\mathrm{hP}_{2}{ }_{14}$ receptor (Carter et al., 2009). Previous $\mathrm{Ca}^{2+}$ signalling assays in tsA201 cells in the Kennedy lab group have suggested a small response to UDP-glucose from $100 \mathrm{nM}$ to 100 $\mu \mathrm{M}$, but similarly to this project no response to UDP at $10 \mu \mathrm{M}$ (Naughton, 2014). In contrast, other studies with WT HEK-293 derived cell lines have reported no $\mathrm{Ca}^{2+}$ response to UDP or UDP-glucose (Werry et al., 2002), except when co-expressing chimeric Ga subunits (Moore et al., 2003). This is because $h P 2 Y_{14}$ does not couple to the $G_{q}$ subunit, so it is unclear why Naughton (2014) found a response; there is evidence that in other cell lines the $P 2 Y_{14} G_{i / 0} \beta Y$ subunit may act on $\mathrm{PLC} \beta$ and induce $\mathrm{Ca}^{2+}$ signalling, or that the $\mathrm{hP} 2 \mathrm{Y}_{14}$ receptor may mediate $\mathrm{Ca}^{2+}$ signalling through the $\mathrm{hP} 2 \mathrm{Y}_{6}$ receptor, similar to the $\mathrm{hP} 2 \mathrm{Y}_{1}-\mathrm{hP} 2 \mathrm{Y}_{12}$ relationship (Bianco et al., 2005; Wypych and Barańska, 2013). These signalling effects have not been characterised in HEK-293 type cell lines though, and additionally both UDP and UDPglucose have been identified as failing to inhibit forskollin mediated cAMP accumulation in wild type HEK-293 cells (Carter et al., 2009), which suggests the absence of hP2Y 14 receptors.

Without further data using UDP-glucose, cAMP inhibition assays and selective hP2Y, ligands, any conclusions on the presence of functional hP2 $\mathrm{Y}_{6}$ or $\mathrm{hP}_{2} \mathrm{Y}_{14}$ receptors in the tsA201 cell line are at best speculation. However, based on the available data hP2 $\mathrm{Y}_{6}$ receptors are more likely due to them being well established as coupling to the $G_{q}$ subunit and signalling through $\mathrm{Ca}^{2+}$, unlike the $\mathrm{hP} 2 \mathrm{Y}_{14}$ receptor.

It is unclear as to the expression of $\mathrm{hP}_{2} \mathrm{Y}_{11}$ or $\mathrm{hP} 2 \mathrm{Y}_{13}$ receptor mRNA in this project as RTPCR showed no RT+ products of the expected size, but it also unfortunately appeared to fail to amplify any of the positive controls correctly. Raising the primers concentrations and plasmid amounts only gave products which were substantially larger than expected, and likely represent mis-primes or the plasmid vector itself as the cycler extension time was insufficient to generate products of the size generated (Tate, personal communication, 2016). The reason for this became apparent when the plasmid sequences were later available: the primers could not bind due to small numbers of nucleotide base changes in the plasmids encoded receptor sequences. This information unfortunately came too late for other positive controls to be sourced; HepG2 cDNA was evaluated as an alternative, but gave no products either, and it is therefore possible that it did not express mRNA for either receptor despite the previous reports. 
The products formed in the RT- controls in this study are likely reflective of a low concentration of contaminating genomic DNA based on their sequences matching the expected PCR products. This is despite the multiple rounds of DNAse I treatment, but Schachter et al. (1997) have reported experiencing a similar issue with $\mathrm{hP} 2 \mathrm{Y}_{1}$ and $\mathrm{hP} 2 \mathrm{Y}_{2}$ receptor $\mathrm{RT}$-PCR. It is interesting that RNAse $\mathrm{I}_{\mathrm{f}}$ treatment of the templates caused large reductions in $\mathrm{hP}_{2} \mathrm{Y}_{1}$ receptor $\mathrm{RT}$ - band staining, but not with the $\mathrm{hP} 2 \mathrm{Y}_{2}$ receptor $\mathrm{RT}-$, and it did not affect the RT+ for either, which could suggest an off-target reverse transcriptase action of the polymerase on the RNA present in the RT-. This is seen as unlikely with a Taq based PCR polymerase mastermix like used (Shi et al., 2015), especially as reverse transcriptase activity is $\mathrm{Mn}^{2+}$ dependent compared to the $\mathrm{Mg}^{2+}$ required for $\mathrm{PCR}$ polymerase activity (Mülhardt and Beese, 2007). Alternatively, the products could represent pseudogenes for the receptors, but no pseudo-genes are currently known to exist in the hP2Y receptor family, except for possibly the hP2Y6 receptor (Maier et al., 1997).

Similarly, the reasons for the amplicons forming in the water controls are unclear, but contamination of the reagents by airborne plasmid DNA or previous PCR products looks to be the most obvious cause, and these likely additionally contributed to the RT- bands. This theory is supported by how setting up the PCR reactions in a UV exposed laminar flow cabinet appeared to eliminate the amplicons on nearly all occasions, and also reduced or removed the RT- bands in the majority of cases.

It is accepted that the functional data presented here is limited in that selective pharmacological ligands were not used, so any conclusions on most individual receptors presence are more speculative than explicit. Additionally, another especially valid point is that as briefly mentioned the $P 2 Y_{12}$ like $G_{i / o}$ coupled receptors are traditionally not characterised as signalling, at least directly, through intracellular $\mathrm{Ca}^{2+}$.

\subsubsection{Tagged Receptor Construct Cellular Expression}

In order to determine if the HA or FP tagged $\mathrm{hP}_{2} \mathrm{Y}_{1}$ and $\mathrm{hP} 2 \mathrm{Y}_{12}$ receptor constructs were functionally expressed in the tsA201 cell line following transfection, $\mathrm{Ca}^{2+}$ flux assays were used to determine the responses to ligands. ADP stimulated a response in wild type tsA201 cells with a similar potency to past studies with the cell line in the lab group (Naughton et al., 2014) and also other HEK-293 type cell lines (Mundell and Benovic, 2000; Werry et al,.

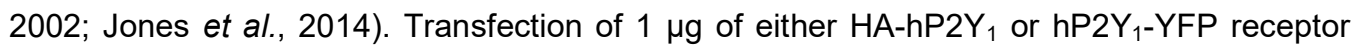
cDNA was associated with a leftward shift in the fitted concentration response curve, a 
corresponding increase in the $\mathrm{pEC}_{50}$ and a slightly raised $\mathrm{E}_{\max }$. This is consistent with receptor overexpression and there being an increased number of binding sites present (Chen et al., 2000).

The transfection also significantly reduced the Hill slope for both of the tagged hP2 $\mathrm{Y}_{1}$ receptor constructs compared to the WT cells, which was likely a result of the receptor overexpression moving a greater proportion of receptors to a higher affinity, activated state and thereby raising basal activity levels (Chen et al., 2000; Kenakin, 2014). Another possibility is that this reflects the heterogeneous mixed population of the overexpressed transfected receptors and the endogenous receptors present, so the balance of the P2Y receptors expressed had been un-naturally shifted, which thereby induced differing combinations of receptor conformational or dimeric states that showed varying affinities to ADP (Colquhoun, 1998).

To test for expression of the tagged $\mathrm{hP}_{2} \mathrm{Y}_{12}$ receptor constructs, the cells were transfected with $1 \mu \mathrm{g}$ of $\mathrm{HA}-\mathrm{hP} 2 \mathrm{Y}_{12}$ or $\mathrm{hP}_{2} \mathrm{Y}_{12}-\mathrm{CFP} \mathrm{cDNA}$. The cells were repeatedly stimulated with 300 $\mathrm{nM}$ of ADP (this being close to the $\mathrm{EC}_{50}$ of WT tsA201 cells), which demonstrated reproducible responses for both plasmids; the response was then measured again when in the presence of $1 \mu \mathrm{M}$ of the $\mathrm{hP}_{2} \mathrm{Y}_{12}$ receptor antagonist cangrelor and again after washout. In WT tsA201 cells cangrelor has been found in previous work in the lab group to have no inhibitory effect on $\mathrm{Ca}^{2+}$ signals (Naughton et al., 2014) due to its target hP2Y 12 receptors not being $G_{q}$ coupled, but in this project when either of the $h P 2 Y_{12}$ receptor plasmids were expressed in the cell line the cangrelor significantly suppressed the $\mathrm{Ca}^{2+}$ response and the prior response to $300 \mathrm{nM}$ ADP was restored after washout. This corresponds with the previous studies in the lab group, and suggests that $\mathrm{hP}_{2} \mathrm{Y}_{12}$ receptors had been functionally expressed as the ADP induced $\mathrm{Ca}^{2+}$ signals were sensitive to cangrelor, which only directly acts competitively on $\mathrm{hP}_{2} \mathrm{Y}_{12}$ receptors and has no action on the endogenous $\mathrm{hP} 2 \mathrm{Y}_{1}$ receptors inducing the $\mathrm{Ca}^{2+}$ signal (Suzuki et al., 2011). It is fully accepted however that this was not the most appropriate method to determine $\mathrm{hP}_{2} \mathrm{Y}_{12}$ receptor expression as they do not directly couple to $\mathrm{Ca}^{2+}$ signalling, and cAMP inhibition assays would have been more suitable.

Overall this suggested that the HA or FP tagged forms of the $\mathrm{hP}_{2} \mathrm{Y}_{1}$ and $\mathrm{hP} 2 \mathrm{Y}_{12}$ receptors could be functionally expressed in the tsA201 cell line. Therefore, they could be used in coimmunoprecipitation studies to try to detect physical interactions between the two receptors. 


\subsubsection{Interactions between the $\mathrm{hP}_{2} \mathrm{Y}_{1}$ and $\mathrm{hP2}_{12} \underline{\text { receptors }}$}

To try to determine if the $\mathrm{hP}_{2} \mathrm{Y}_{1}$ and $\mathrm{hP}_{2} \mathrm{Y}_{12}$ receptors physically interacted to form a functional constitutive heterodimer as per the theory proposed by Shrestha et al. (2010), coimmunoprecipitation experiments were performed. In the first set of experiments it was confirmed that when transfected in individually both the HA and FP tagged forms of the receptors could be successfully immunoprecipitated from the initial whole cell lysate "inputs" using the respective antibody conjugated agarose beads. The "smear" staining and multiple bands present on the Western blots likely represent various post-translationally modified forms of the receptors, for example by glycosylation (Yoshioka et al., 2001; Zhong et al., 2004) and homodimer formation. Both hP2 $\mathrm{Y}_{1}$ (Choi et al., 2008) and $\mathrm{hP} 2 \mathrm{Y}_{12}$ receptors are known to form homodimers, with the heavier bands visible in the $\mathrm{hP}^{2} \mathrm{Y}_{12}$ receptor anti-GFP IP corresponding with the report by Savi et al. (2006) of dimeric and oligomeric hP2 12 receptor complexes. These were not as prominent in the anti-HA IP, which may be related to the resolving gel percentage being inappropriate for the size of the protein, and/or the concentration of DTT used, which $\mathrm{P}_{2} \mathrm{Y}_{12}$ receptor homo-oligomers are sensitive to (Savi et al., 2006).

As the individual receptors could be immunoprecipitated, it was then moved on to the main aim of whether co-expressed receptors could be HA co-immunoprecipitated: one HA tagged $\mathrm{hP}_{2} \mathrm{Y}_{1}$ or $\mathrm{hP}_{2} \mathrm{Y}_{12}$ receptor was co-expressed with an FP tagged version of the opposing receptor. These were in addition to no-cDNA and HA tagged receptor plus GFP control samples to detect any non-specific signals or protein aggregation.

On the one co-IP experiment performed, the formation of a detectable higher molecular weight protein of $\sim 130$ to $>250 \mathrm{KDa}$ (based on pre-stained protein standards) and expressing an FP tag was visible in samples expressing HA-hP2 $\mathrm{Y}_{1}+\mathrm{hP} 2 \mathrm{Y}_{12}$-CFP or HA$h P 2 Y_{12}+h P 2 Y_{1}-Y F P$ receptors when immunoprecipitating for the HA tag and blotting for the FP tag. This suggested a physical association between the two receptors as the FP tagged receptor had been immunoprecipitated with the HA tagged receptor rather than being purified out. With the tools used though it is difficult to know with any certainty what the complex was comprised of due to the likelihood of both post-translational modifications of the receptors and from dimers forming between other receptors or proteins present (discussed further later on). 
The no-cDNA, HA-hP2Y 1 receptor co-expressed with GFP and HA-hP2Y 12 receptor coexpressed with GFP controls did not show signals, implying that this was not due to protein aggregation during cell lysis, however protein was present in all the inputs before the IP as demonstrated by the strong anti- $\beta$-tubulin staining at the expected $\sim 55 \mathrm{KDa}$. This heavier FP tag expressing protein complex was furthermore visible when blotting for the HA tagged receptor, which confirmed the presence of both tagged receptors in the complex. These results potentially could suggest the formation of a constitutive heterodimer complex between the $\mathrm{hP}_{2} \mathrm{Y}_{1}$ and $\mathrm{hP} 2 \mathrm{Y}_{12}$ receptors, but based on the tools used, and as it is only from a single experiment, it is not possible to currently either support or refute this hypothesis; there is past literature (detailed below) both for and against the formation of a specific heterodimer. It is also important to remember the dynamic nature of dimerisation as this experiment only represents the cells at a single point in time, and any heterodimer may form or dissociate in response to other factors such as receptor density or agonist stimulation.

Evidence for the formation of a constitutive heterodimer between $h P 2 Y_{1}$ and $h P 2 Y_{12}$ receptors has been previously presented by Schicker et al. (2009) based on FRET studies in the tsA201 cell line where co-transfection of the two receptors was associated with a significant FRET signal. However, this was also the result when most other hP2Y receptors were transfected in, raising doubt as to whether this could have been a non-specific effect of the FRET study - even though the authors took great care with positive and negative controls -, or if purinergic receptors will promiscuously dimerise with other receptors to exert required physiological signalling pathways as the authors proposed. Indeed, not only P2Y receptors, but also various co-expressed adenosine receptor subtypes were associated with an increase in FRET signal, including adenosine $A_{1}$ or $A_{2 A}$ receptors when co-expressed with $\mathrm{hP}_{2} \mathrm{Y}_{1}$ or $\mathrm{hP}_{2} \mathrm{Y}_{12}$ receptors. $\mathrm{A}_{1}-\mathrm{P}_{2} \mathrm{Y}_{1}$ heterodimers have already been characterised previously (Yoshioka et al., 2001; Yoshioka et al., 2002), but for both the hP2Y 1 and hP2Y 12 receptors physical interaction was also confirmed with $\mathrm{A}_{2 \mathrm{~A}}$ receptors by co-IP in the Schicker et al. study. It is known that HEK-293T cells (Suzuki et al., 2011) and the parent HEK-293 cell line (Inbe et al., 2004) endogenously express $A_{1}$ and $A_{2 A}$ receptors, so there could a third or potentially even greater number of partners involved in any dimerisation or crosstalk between $\mathrm{hP}_{2} \mathrm{Y}_{1}$ and $\mathrm{hP} 2 \mathrm{Y}_{12}$ receptors in tsA201 cells. This may potentially explain the high molecular weight of the co-immunoprecipitated complex in this project, especially as a possible multimeric $\mathrm{P}_{2} \mathrm{Y}_{1}-\mathrm{P}_{2} \mathrm{Y}_{12}-\mathrm{A}_{2 \mathrm{~A}}$ receptor complex has already been described by Nakata et al. (2010).

The other possibility for the proposed dimerisation effects previously observed in the signalling assays is that they could be from receptor cross talk without any physical 
interaction. The $\mathrm{G}_{\mathrm{i} / \mathrm{o}}$ linked $\mathrm{hP} 2 \mathrm{Y}_{12}$ receptor is unable to directly induce $\mathrm{Ca}^{2+}$ release itself, but there is extensive research in both platelets (Hardy et al., 2004) and C6 glioma cells (Barańska et al., 2004; Suplat et al. 2007; Wypych and Barańska, 2013) which indicates that $\mathrm{hP}_{2} \mathrm{Y}_{1}$ and $\mathrm{hP} 2 \mathrm{Y}_{12}$ receptors have a synergistic relationship to regulate agonist induced $\mathrm{Ca}^{2+}$ release, similar to as described in the tsA201 cells by Naughton et al., 2014. The signalling appears to be triggered and negatively modulated through the $\mathrm{hP}_{2} \mathrm{Y}_{1}$ receptor and positively modulated through the activated $\mathrm{hP}_{2} \mathrm{Y}_{12}$ receptors inhibitory actions on cAMP as the effect is PTX-sensitive, again similar to as characterised in the previous tsA201 cell signalling studies. The platelet and C6 glioma studies mentioned have further indicated that the link between the two receptors which enables $\mathrm{hP}_{2} \mathrm{Y}_{12}$ to modulate $\mathrm{Ca}^{2+}$ release appears be the activation of phosphatidylinositol-4,5-bisphosphate 3-kinase (PI3-K), the activity of which is up-regulated by the $\mathrm{hP} 2 \mathrm{Y}_{12}$ receptor mediated inhibition of cAMP, but is down-regulated by $\mathrm{hP} 2 \mathrm{Y}_{1}$ receptor activation. This data however has not been characterised yet in any HEK293 type cells so it is unknown if it may apply to the signalling effects seen in tsA201 cells. The overall potential signalling pathways and heterodimer formations in the tsA201 cell line in this discussion section are visually presented in Figure 14.

It is interesting to note that for the co-IP experiment performed in this project, co-expression of both $\mathrm{hP}_{2} \mathrm{Y}_{1}$ and $\mathrm{hP} 2 \mathrm{Y}_{12}$ receptors appeared to cause a decrease in expression on the Western blot compared to the singular receptors co-expressed with GFP controls; this may suggest that the $\mathrm{hP}_{2} \mathrm{Y}_{1}$ and $\mathrm{hP}_{2} \mathrm{Y}_{12}$ receptors have a dynamic effect on each other's expression levels. Whilst siRNA knockdown of $\mathrm{hP}_{2} \mathrm{Y}_{1}$ receptors did not appear to have a subsequent effect on $\mathrm{hP}_{2} \mathrm{Y}_{12}$ mRNA expression in C6 glioma cells in one study (Wypych and Pomorski, 2012), factors such as the presence or absence of serum in the culture media have been found to alter the molecular and surface expression of the two receptors and promote the modulating pathway of one receptor over the other (Wypych and Barańska, 2013). The other possibility is that this reduced expression was simply from a non-specific decrease in transfection efficiency induced by co-expression of the additional GPCR, but there was insufficient time to test this hypothesis using an unrelated receptor. 


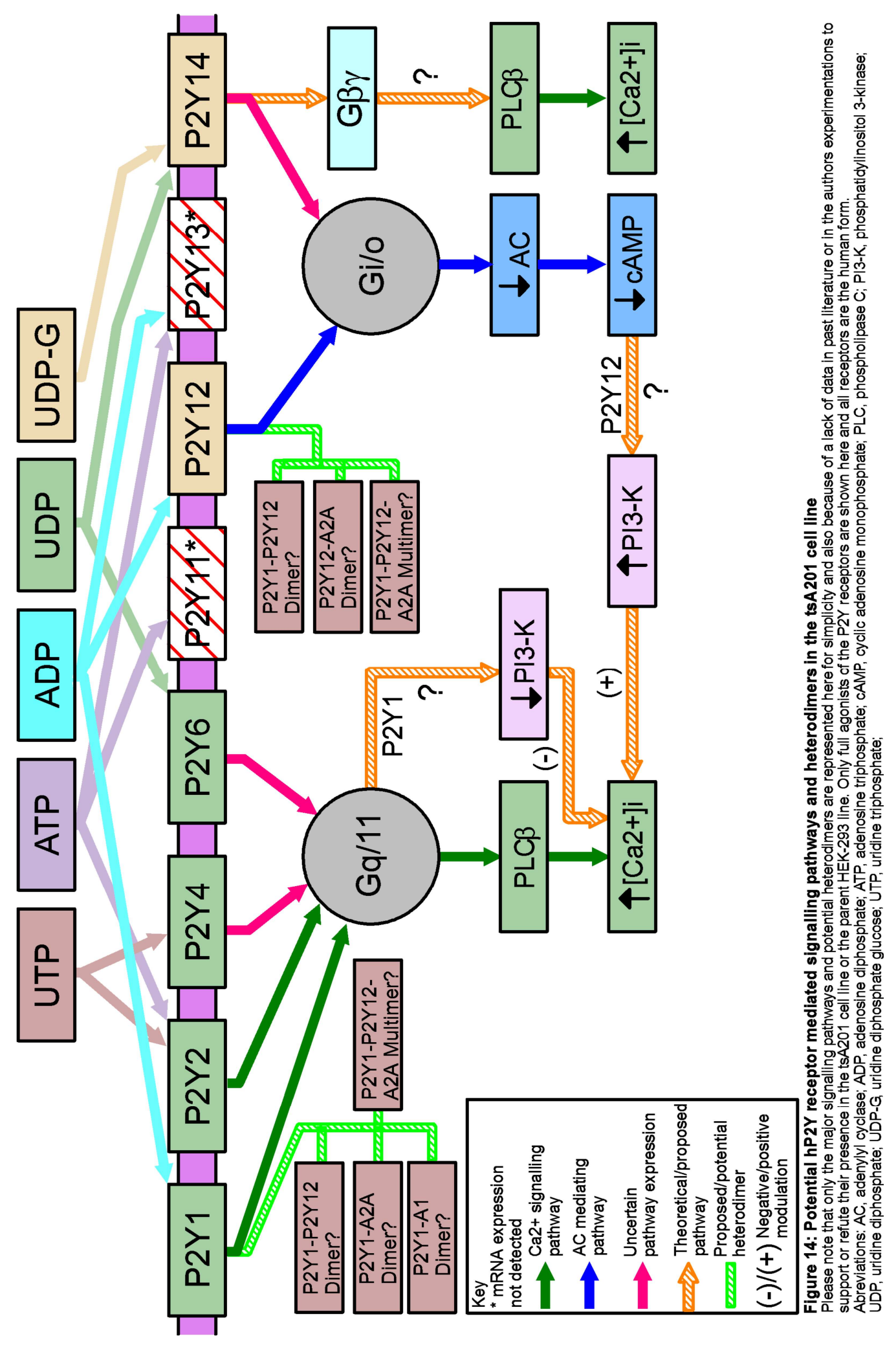


One particularly pertinent point though is that the signalling phenomenon proposed to indicate formation of a hP2 $\mathrm{Y}_{1}-\mathrm{hP} 2 \mathrm{Y}_{12}$ receptor heterodimer by the Shrestha et al. (2010) and Naughton et al. (2014) studies has only ever been characterised in tsA201 cells. Therefore, the signalling effects could be from the influence of any of the many endogenously expressed purinergic family receptors, or indeed simply be a cell line specific effect. It is therefore proposed that signalling, co-localisation and co-IP studies need to be characterised in another cell line to exclude this possibility, whether or not the two receptors ultimately are confirmed to co-immunoprecipitate in tsA201 cells.

This itself however leads on to another important question: even if this dimer complex can be co-immunoprecipitated in an overexpression system, does it exist in native cells, or moreover in an in-vivo system and if so what is its functional purpose? Although $\mathrm{P}_{2} \mathrm{Y}_{1}$ and $\mathrm{P}^{2} \mathrm{Y}_{12}$ receptors are both known to have roles in pain in animal models, there is a present deficiency in information on their roles in human pain. The mixed pro/anti nociceptive effects of stimulating/inhibiting ligands at the individual $P 2 Y_{1}$ and $P 2 Y_{12}$ receptors further makes it uncertain as to the form of any ligand that could target the dimer - would it be an agonist or antagonist?. It is unclear therefore as to whether a $\mathrm{hP} 2 \mathrm{Y}_{1}-\mathrm{hP} 2 \mathrm{Y}_{12}$ receptor heterodimer could even be a viable target for the modulation of pain sensing neurones, as postulated from the results of the Shrestha et al. (2010) study.

\subsubsection{Conclusions}

To conclude, in this project it was aimed to investigate endogenous hP2Y receptor expression in the tsA201 cell line, confirm that the new tagged receptor constructs could be functionally expressed in the cell line and examine whether the tagged $h P 2 Y_{1}$ and $h P 2 Y_{12}$ receptors physically interacted and could be co-immunoprecipitated. Molecular expression of hP2Y 1, 2, 4, 6, 12, 14 receptor mRNA was indicated by RT-PCR and Sanger sequencing. Furthermore, functional $\mathrm{Ca}^{2+}$ flux assays indicated responses to ADP, ATP, UDP and UTP, which based on previous literature suggests functional expression of $h P 2 Y_{1,2}, 12$ receptors and possibly hP2Y 4,6, 14 receptors, but additional studies need to be completed to clarify this. The HA or FP tagged receptor constructs were successfully functionally expressed in the cell line, and when the $\mathrm{hP}_{2} \mathrm{Y}_{1}$ and $\mathrm{hP} 2 \mathrm{Y}_{12}$ receptors were co-expressed together it was possible to co-immunoprecipitate a higher molecular weight complex bearing the opposing tag to that immunoprecipitated, therefore implying the formation of a possible constitutive heterodimer complex. Because of other potentially interacting receptors, and as this co-IP data is based 
on a single experiment, it is not possible with the current information to confirm or refute the formation of specific $h P 2 Y_{1}-h P 2 Y_{12}$ heterodimers in the tsA201 cell line.

\subsubsection{Potential Future Work}

The data presented in this study is suggestive of several hP2Y receptor subtypes being expressed in the tsA201 cell line. P2Y receptor antibodies have been associated with a high degree of cross-reactivity (Tung et al., 2004), but various studies discussed here have been able to successfully use antibody mediated techniques. It is suggested therefore that this would be a viable future direction in which to ascertain endogenous tsA201 P2Y receptor expression, along with using selective ligands, cAMP assays and quantitative RNA sequencing of the cell line to give an overall, detailed insight into the receptors expressions.

The co-IP data in the tsA201 cell line needs to be repeated in order to confirm any reproducibility, along with investigating the effect of factors such as agonist stimulation on any potential dimer formation; co-localisation and RET studies could be used to further investigate these in live cells and to confirm if the receptors co-localise. As discussed there is a strong probability of interactions with other endogenous receptors in the tsA201 cell line, so the signalling and co-IP data ideally needs to additionally be characterised in another cell line to exclude this possibility; selective gene knockdown of endogenous receptors in the tsA201 cells could also be used to determine whether the presence/absence of any specific receptor type alters the results. Utilising stably transfected $1321 \mathrm{~N} 1$ cells, which lack endogenous $\mathrm{P} 2 \mathrm{Y}$ receptors, could represent one option as it removes the presence of most other potentially influencing receptors, and furthermore bypasses the possibility of experimental variances induced through transient transfection. As PI3-K has previously been reported to be the linking mechanism through which $\mathrm{hP}_{2} \mathrm{Y}_{1}$ and $\mathrm{hP} 2 \mathrm{Y}_{12}$ receptors can both modulate $\mathrm{Ca}^{2+}$ release in other cell types, its activity should be additionally assessed to determine if this is simply a subset of the crosstalk already characterised in other cells, or a unique mechanism. Depending on the results of these studies, potential longer term work could involve trying to investigate the effects in native receptors, in ex-vivo tissue or in-vivo. 


\section{References}

Abbracchio, M.P., Burnstock, G., 1994. Purinoceptors: Are there families of P2X and P2Y purinoceptors? Pharmacol. Ther. 64, 445-475.

Abbracchio, M.P., Burnstock, G., Boeynaems, J.-M., Barnard, E.A., Boyer, J.L., Kennedy, C., Knight, G.E., Fumagalli, M., Gachet, C., Jacobson, K.A., Weisman, G.A., 2006. International Union of Pharmacology LVIII: Update on the P2Y G Protein-Coupled Nucleotide Receptors: From Molecular Mechanisms and Pathophysiology to Therapy. Pharmacol. Rev. 58, 281-341.

Abbracchio, M.P., Burnstock, G., Boeynaems, J.-M., Barnard, E.A., Boyer, J.L., Kennedy, C., Miras-Portugal, M.T., King, B.F., Gachet, C., Jacobson, K.A., Weisman, G.A., 2005. The recently deorphanized GPR80 (GPR99) proposed to be the P2Y15 receptor is not a genuine P2Y receptor. Trends Pharmacol. Sci. 26, 8-9.

Agrawal, S., Harburger, J., Stallings, G., Agrawal, N., Garg, J., 2013. Clopidogrel-Induced Recurrent Polyarthritis. J. Investig. Med. High Impact Case Reports 1.

Almeida, T.F., Roizenblatt, S., Tufik, S., 2004. Afferent pain pathways: a neuroanatomical review. Brain Res. 1000, 40-56.

Andó, R.D., Méhész, B., Gyires, K., Illes, P., Sperlágh, B., 2010. A comparative analysis of the activity of ligands acting at $\mathrm{P} 2 \mathrm{X}$ and $\mathrm{P} 2 \mathrm{Y}$ receptor subtypes in models of neuropathic, acute and inflammatory pain. Br. J. Pharmacol. 159, 1106-1117.

Angers, S., Salahpour, A., Joly, E., Hilairet, S., Chelsky, D., Dennis, M., Bouvier, M., 2000. Detection of $\beta 2$-adrenergic receptor dimerization in living cells using bioluminescence resonance energy transfer (BRET). Proc. Natl. Acad. Sci. 97, 3684-3689.

Atwood, B.K., Lopez, J., Wager-Miller, J., Mackie, K., Straiker, A., 2011. Expression of G protein-coupled receptors and related proteins in HEK293, AtT20, BV2, and N18 cell lines as revealed by microarray analysis. BMC Genomics $12,1-14$.

Barańska, J., Czajkowski, R., Sabała, P., 2004. Cross-talks between nucleotide receptorinduced signaling pathways in serum-deprived and non-starved glioma C6 cells. Adv. Enzyme Regul. 44, 219-232. 
Barragán-Iglesias, P., Mendoza-Garcés, L., Pineda-Farias, J.B., Solano-Olivares, V., Rodríguez-Silverio, J., Flores-Murrieta, F.J., Granados-Soto, V., Rocha-González, H.I., 2015. Participation of peripheral P2Y1, P2Y6 and P2Y11 receptors in formalin-induced inflammatory pain in rats. Pharmacol. Biochem. Behav. 128, 23-32.

Basbaum, A.I., Bautista, D.M., Scherrer, G., Julius, D., 2009. Cellular and Molecular Mechanisms of Pain. Cell 139, 267-284.

Beaulieu, J.-M., Gainetdinov, R.R., 2011. The Physiology, Signaling, and Pharmacology of Dopamine Receptors. Pharmacol. Rev. 63, 182-217.

Bennett, G.J., 2000. Update on the Neurophysiology of Pain Transmission and Modulation: Focus on the NMDA-Receptor. J. Pain Symptom Manage. 19, 2-6.

Bettler, B., Kaupmann, K., Mosbacher, J., Gassmann, M., 2004. Molecular Structure and Physiological Functions of GABAB Receptors. Physiol. Rev. 84, 835-867.

Bianco, F., Fumagalli, M., Pravettoni, E., D’Ambrosi, N., Volonte, C., Matteoli, M., Abbracchio, M.P., Verderio, C., 2005. Pathophysiological roles of extracellular nucleotides in glial cells: differential expression of purinergic receptors in resting and activated microglia. Brain Res. Rev. 48, 144-156.

Bortolato, A., Mobarec, J.C., Provasi, D., Filizola, M., 2009. Progress in Elucidating the Structural and Dynamic Character of G Protein-Coupled Receptor Oligomers for Use in Drug Discovery. Curr. Pharm. Des. 15, 4017-4025.

Burnstock, G., 2009. Purinergic signalling: past, present and future. Brazilian J. Med. Biol. Res. 42, 3-8.

Burnstock, G., Kennedy, C., 1985. Is there a basis for distinguishing two types of P2purinoceptor? Gen. Pharmacol. Vasc. Syst. 16, 433-440.

Burnstock, G., 2013a. Purinergic Signalling: Pathophysiology and Therapeutic Potential. Keio J. Med. 62, 63-73.

Burnstock, G., 2013.b Purinergic mechanisms and pain-An update. Eur. J. Pharmacol. 716, 24-40. 
Burnstock, G., Sawynok, J., 2010. Adenosine Triphosphate And Adenosine Receptors and Pain. In: Beaulieu, P., Lussier, D., Porreca, F., Dickenson, A.H. (Eds.), Pharmacology of Pain. IASP Press, Washington D.C, pp. 303-326.

Calebiro, D., Rieken, F., Wagner, J., Sungkaworn, T., Zabel, U., Borzi, A., Cocucci, E., Zürn, A., Lohse, M.J., 2013. Single-molecule analysis of fluorescently labeled G-proteincoupled receptors reveals complexes with distinct dynamics and organization. Proc. Natl. Acad. Sci. 110, 743-748.

Calver, A.R., Medhurst, A.D., Robbins, M.J., Charles, K.J., Evans, M.L., Harrison, D.C., Stammers, M., Hughes, S.A., Hervieu, G., Couve, A., Moss, S.J., Middlemiss, D.N., Pangalos, M.N., 2000. The expression of GABAB1 and GABAB2 receptor subunits in the cNS differs from that in peripheral tissues. Neuroscience 100, 155-170.

Carter, R.L., Fricks, I.P., Barrett, M.O., Burianek, L.E., Zhou, Y., Ko, H., Das, A., Jacobson, K.A., Lazarowski, E.R., Harden, T.K., 2009. Quantification of G(i)-Mediated Inhibition of Adenylyl Cyclase Activity Reveals That UDP Is a Potent Agonist of the Human P2Y(14) Receptor. Mol. Pharmacol. 76, 1341-1348.

Chabre, M., le Maire, M., 2005. Monomeric G-Protein-Coupled Receptor as a Functional Unit. Biochemistry 44, 9395-9403.

Chakrabarti, S., Liu, N.-J., Gintzler, A.R., 2010. Formation of $\mu$-/k-opioid receptor heterodimer is sex-dependent and mediates female-specific opioid analgesia. Proc. Natl. Acad. Sci. 107, 20115-20119.

Chen, G., Way, J., Armour, S., Watson, C., Queen, K., Jayawickreme, C.K., Chen, W.-J., Kenakin, T., 2000. Use of Constitutive G Protein-Coupled Receptor Activity for Drug Discovery. Mol. Pharmacol. 57, 125-134.

Choi, R.C.Y., Simon, J., Tsim, K.W.K., Barnard, E.A., 2008. Constitutive and Agonistinduced Dimerizations of the P2Y1 Receptor: RELATIONSHIP TO INTERNALIZATION AND SCAFFOLDING. J. Biol. Chem. 283, 11050-11063.

Cohen, S.P., Mao, J., 2014. Neuropathic pain: mechanisms and their clinical implications. BMJ 348. 
Collier, H.O.J., James, G.W.L., Schneider, C., 1966. Antagonism by Aspirin and Fenamates of Bronchoconstriction and Nociception induced by Adenosine-5[prime]-triphosphate. Nature 212, 411-412.

Colquhoun, D., 1998. Binding, gating, affinity and efficacy: The interpretation of structureactivity relationships for agonists and of the effects of mutating receptors. Br. J. Pharmacol. 125, 923-947.

Costigan, M., Scholz, J., Woolf, C.J., 2009. Neuropathic Pain: A Maladaptive Response of the Nervous System to Damage. Annu. Rev. Neurosci. 32, 1-32.

Coulter, C.J., Montandon, S. V, 2012. Prasugrel as a Safe Alternative for ClopidogrelInduced Polyarthralgias. Pharmacother. J. Hum. Pharmacol. Drug Ther. 32, e24-e26.

Couve, A., Filippov, A.K., Connolly, C.N., Bettler, B., Brown, D.A., Moss, S.J., 1998. Intracellular Retention of Recombinant GABAB Receptors. J. Biol. Chem. 273, 2636126367.

Dakik, H.A., Salti, I., Haidar, R., Uthman, I.W., 2002. Ticlopidine associated with acute arthritis. BMJ 324, 27.

D’Ambrosi, N., lafrate, M., Saba, E., Rosa, P., Volonté, C., 2007. Comparative analysis of P2Y4 and P2Y6 receptor architecture in native and transfected neuronal systems. Biochim. Biophys. Acta - Biomembr. 1768, 1592-1599.

D’Ambrosi, N., lafrate, M., Vacca, F., Amadio, S., Tozzi, A., Mercuri, N., Volonté, C., 2006. The P2Y4 receptor forms homo-oligomeric complexes in several CNS and PNS neuronal cells. Purinergic Signal. 2, 575-582.

Devor, M., 2009. Ectopic discharge in $A \beta$ afferents as a source of neuropathic pain. Exp. Brain Res. 196, 115-128.

Dickson, E.J., Falkenburger, B.H., Hille, B., 2013. Quantitative properties and receptor reserve of the IP3 and calcium branch of Gq-coupled receptor signaling. J. Gen. Physiol. 141, 521-535.

Dubin, A.E., Patapoutian, A., 2010. Nociceptors: the sensors of the pain pathway. J. Clin. Invest. 120, 3760-3772. 
Ecke, D., Hanck, T., Tulapurkar, M.E., Schäfer, R., Kassack, M., Stricker, R., Reiser, G., 2008. Hetero-oligomerization of the P2Y11 receptor with the P2Y1 receptor controls the internalization and ligand selectivity of the P2Y11 receptor. Biochem. J. 409, 107-116.

Erb, L., Weisman, G.A., 2012. Coupling of P2Y receptors to G proteins and other signaling pathways. Wiley Interdiscip. Rev. Membr. Transp. Signal. 1, 789-803.

Fabbretti, E., 2013. ATP P2X3 receptors and neuronal sensitization. Front. Cell. Neurosci. 7.

Ferre, S., Baler, R., Bouvier, M., Caron, M.G., Devi, L.A., Durroux, T., Fuxe, K., George, S.R., Javitch, J.A., Lohse, M.J., Mackie, K., Milligan, G., Pfleger, K.D.G., Pin, J.-P., Volkow, N.D., Waldhoer, M., Woods, A.S., Franco, R., 2009. Building a new conceptual framework for receptor heteromers. Nat Chem Biol 5, 131-134.

Ferré, S., Casadó, V., Devi, L.A., Filizola, M., Jockers, R., Lohse, M.J., Milligan, G., Pin, J.P., Guitart, X., 2014. G Protein-Coupled Receptor Oligomerization Revisited: Functional and Pharmacological Perspectives. Pharmacol. Rev. 66, 413-434.

Fischer, W., Wirkner, K., Weber, M., Eberts, C., Köles, L., Reinhardt, R., Franke, H., Allgaier, C., Gillen, C., Illes, P., 2003. Characterization of P2X3, P2Y1 and P2Y4 receptors in cultured HEK293-hP2X3 cells and their inhibition by ethanol and trichloroethanol. J. Neurochem. 85, 779-790.

Fotiadis, D., Liang, Y., Filipek, S., Saperstein, D.A., Engel, A., Palczewski, K., 2004. The G protein-coupled receptor rhodopsin in the native membrane. FEBS Lett. 564, 281-288.

Fraser, C.M., Venter, J.C., 1982. The size of the mammalian lung $\beta 2$-adrenergic receptor as determined by target size analysis and immunoaffinity chromatography. Biochem. Biophys. Res. Commun. 109, 21-29.

Fricks, I.P., Maddileti, S., Carter, R.L., Lazarowski, E.R., Nicholas, R.A., Jacobson, K.A., Harden, T.K., 2008. UDP Is a Competitive Antagonist at the Human P2Y14 Receptor. J. Pharmacol. Exp. Ther. 325, 588-594.

Gachet, C., 2012. P2Y(12) receptors in platelets and other hematopoietic and nonhematopoietic cells. Purinergic Signal. 8, 609-619.

Garg, A., Radvan, J., Hopkinson, N., 2000. Clopidogrel associated with acute arthritis. BMJ $320,483$. 
George, S.R., Fan, T., Xie, Z., Tse, R., Tam, V., Varghese, G., O'Dowd, B.F., 2000. Oligomerization of $\mu$ - and $\delta$-Opioid Receptors: Generation of Novel Functional Properties. J. Biol. Chem. 275, 26128-26135.

Gereau, R.W., Cavallone, L.F., 2013. Mechanisms of pain transmission and transduction. Anesth. Pharmacol. Basic Princ. Clin. Pract.

Goddard, A.D., Watts, A., 2012. Contributions of fluorescence techniques to understanding G protein-coupled receptor dimerisation. Biophys. Rev. 4, 291-298.

Gomes, I., Jordan, B.A., Gupta, A., Trapaidze, N., Nagy, V., Devi, L.A., 2000. Heterodimerization of $\mu$ and $\delta$ Opioid Receptors: A Role in Opiate Synergy. J. Neurosci. 20, RC110-RC110.

Gomes, I., Gupta, A., Filipovska, J., Szeto, H.H., Pintar, J.E., Devi, L.A., 2004. A role for heterodimerization of $\mu$ and $\delta$ opiate receptors in enhancing morphine analgesia. Proc. Natl. Acad. Sci. U. S. A. 101, 5135-5139.

Gomes, I., ljzerman, A.P., Ye, K., Maillet, E.L., Devi, L.A., 2011. G Protein-Coupled Receptor Heteromerization: A Role in Allosteric Modulation of Ligand Binding. Mol. Pharmacol. 79, 1044-1052.

Goree, J.R., Lavoie, E.G., Fausther, M., Dranoff, J.A., 2014. Expression of mediators of purinergic signaling in human liver cell lines. Purinergic Signal. 10, 631-638.

Gurevich, V. V, Gurevich, E. V, 2008. GPCR monomers and oligomers: it takes all kinds. Trends Neurosci. 31, 74-81.

Hanack, C., Moroni, M., Lima, W.C., Wende, H., Kirchner, M., Adelfinger, L., SchrenkSiemens, K., Tappe-Theodor, A., Wetzel, C., Kuich, P.H., Gassmann, M., Roggenkamp, D., Bettler, B., Lewin, G.R., Selbach, M., Siemens, J., 2015. GABA Blocks Pathological but Not Acute TRPV1 Pain Signals. Cell 160, 759-770.

Hebert, T.E., Moffett, S., Morello, J.-P., Loisel, T.P., Bichet, D.G., Barret, C., Bouvier, M., 1996. A Peptide Derived from a $\beta 2$-Adrenergic Receptor Transmembrane Domain Inhibits Both Receptor Dimerization and Activation. J. Biol. Chem. 271, 16384-16392.

Heeney, M.M., Hoppe, C.C., Abboud, M.R., Inusa, B., Kanter, J., Ogutu, B., Brown, P.B., Heath, L.E., Jakubowski, J.A., Zhou, C., Zamoryakhin, D., Agbenyega, T., Colombatti, 
R., Hassab, H.M., Nduba, V.N., Oyieko, J.N., Robitaille, N., Segbefia, C.I., Rees, D.C., 2015. A Multinational Trial of Prasugrel for Sickle Cell Vaso-Occlusive Events. N. Engl. J. Med. 374, 625-635.

Hollopeter, G., Jantzen, H.-M., Vincent, D., Li, G., England, L., Ramakrishnan, V., Yang, R.B., Nurden, P., Nurden, A., Julius, D., Conley, P.B., 2001. Identification of the platelet ADP receptor targeted by antithrombotic drugs. Nature 409, 202-207.

Horváth, G., Gölöncsér, F., Csölle, C., Király, K., Andó, R.D., Baranyi, M., Koványi, B., Máté, Z., Hoffmann, K., Algaier, I., Baqi, Y., Müller, C.E., Von Kügelgen, I., Sperlágh, B., 2014. Central P2Y12 receptor blockade alleviates inflammatory and neuropathic pain and cytokine production in rodents. Neurobiol. Dis. 70, 162-178.

Hughes, J.P., Hatcher, J.P., Chessell, I.P., 2007. The role of P2X7 in pain and inflammation. Purinergic Signal. 3, 163-169.

IASP, 2012. IASP Taxonomy. [Online] Available from http://www.iasp-pain.org/Taxonomy. [Accessed: 14/09/2016].

Inbe, H., Watanabe, S., Miyawaki, M., Tanabe, E., Encinas, J.A., 2004. Identification and Characterization of a Cell-Surface Receptor, P2Y15, for AMP and Adenosine. J. Biol. Chem. 279, 19790-19799.

Jacobson, K.A., Ivanov, A.A., de Castro, S., Harden, T.K., Ko, H., 2009. Development of selective agonists and antagonists of P2Y receptors. Purinergic Signal. 5, 75-89.

Jacobson, L.H., Bettler, B., Kaupmann, K., Cryan, J.F., 2006. GABAB(1) Receptor Subunit Isoforms Exert a Differential Influence on Baseline but Not GABAB Receptor AgonistInduced Changes in Mice. J. Pharmacol. Exp. Ther. 319, 1317-1326.

Jacquet, S., Malaval, C., Martinez, L.O., Sak, K., Rolland, C., Perez, C., Nauze, M., Champagne, E., Tercé, F., Gachet, C., Perret, B., Collet, X., Boeynaems, J.M., Barbaras, R., 2005. The nucleotide receptor P2Y13 is a key regulator of hepatic HighDensity Lipoprotein (HDL) endocytosis. Cell. Mol. Life Sci. C. 62, 2508-2515.

Janssens, R., Communi, D., Pirotton, S., Samson, M., Parmentier, M., Boeynaems, J.M., 1996. Cloning and tissue distribution of the human P2Y1 receptor. Biochem. Biophys. Res. Commun. 221, 588-593. 
Jones, K.A., Borowsky, B., Tamm, J.A., Craig, D.A., Durkin, M.M., Dai, M., Yao, W.-J., Johnson, M., Gunwaldsen, C., Huang, L.-Y., Tang, C., Shen, Q., Salon, J.A., Morse, K., Laz, T., Smith, K.E., Nagarathnam, D., Noble, S.A., Branchek, T.A., Gerald, C., 1998. GABAB receptors function as a heteromeric assembly of the subunits GABABR1 and GABABR2. Nature 396, 674-679.

Jin, L.-Q., Goswami, S., Cai, G., Zhen, X., Friedman, E., 2003. SKF83959 selectively regulates phosphatidylinositol-linked D1 dopamine receptors in rat brain. J. Neurochem. 85, 378-386.

Jones, S., Evans, R.J., Mahaut-Smith, M.P., 2014. Ca2+ Influx through P2X1 Receptors Amplifies P2Y1 Receptor-Evoked Ca2+ Signaling and ADP-Evoked Platelet Aggregation. Mol. Pharmacol. 86, 243-251.

Jordan, B.A., Devi, L.A., 1999. G-protein-coupled receptor heterodimerization modulates receptor function. Nature 399, 697-700.

Kamal, M., Maurice, P., Jockers, R., 2011. Expanding the Concept of G Protein-Coupled Receptor (GPCR) Dimer Asymmetry towards GPCR-Interacting Proteins. Pharmaceuticals 4, 273-284.

Kaupmann, K., Huggel, K., Heid, J., Flor, P.J., Bischoff, S., Mickel, S.J., McMaster, G., Angst, C., Bittiger, H., Froestl, W., Bettler, B., 1997. Expression cloning of GABAB receptors uncovers similarity to metabotropic glutamate receptors. Nature 386, 239246.

Kaupmann, K., Malitschek, B., Schuler, V., Heid, J., Froestl, W., Beck, P., Mosbacher, J., Bischoff, S., Kulik, A., Shigemoto, R., Karschin, A., Bettler, B., 1998. GABAB-receptor subtypes assemble into functional heteromeric complexes. Nature 396, 683-687.

Kenakin, T.P., 2014. Chapter 3 - Drug-Receptor Theory. In: A Pharmacology Primer (Fourth Edition). Academic Press, San Diego, pp. 45-62.

Kennedy, C., Chootip, K., Mitchell, C., Syed, N.-I.H., Tengah, A., 2013. P2X and P2Y nucleotide receptors as targets in cardiovascular disease. Future Med. Chem. 5, 431439. 
Kennedy, C., Qi, A.-D., Herold, C.L., Harden, T.K., Nicholas, R.A., 2000. ATP, an Agonist at the Rat P2Y4 Receptor, Is an Antagonist at the Human P2Y4 Receptor. Mol. Pharmacol. 57, 926-931.

Khakh, B.S., Burnstock, G., Kennedy, C., King, B.F., North, R.A., Séguéla, P., Voigt, M., Humphrey, P.P.A., 2001. International Union of Pharmacology. XXIV. Current Status of the Nomenclature and Properties of P2X Receptors and Their Subunits. Pharmacol. Rev. 53, 107-118.

Kruger, L., Kavookjian, A.M., Kumazawa, T., Light, A.R., Mizumura, K., 2003. Nociceptor structural specialization in canine and rodent testicular "free" nerve endings. J. Comp. Neurol. 463, 197-211.

Labianca, R., Sarzi-Puttini, P., Zuccaro, S., Cherubino, P., Vellucci, R., Fornasari, D., 2012. Adverse Effects Associated with Non-opioid and Opioid Treatment in Patients with Chronic Pain. Clin. Drug Investig. 32, 53-63.

Lee, S.P., So, C.H., Rashid, A.J., Varghese, G., Cheng, R., Lança, A.J., O'Dowd, B.F., George, S.R., 2004. Dopamine D1 and D2 Receptor Co-activation Generates a Novel Phospholipase C-mediated Calcium Signal. J. Biol. Chem. 279, 35671-35678.

Limbird, L.E., Lefkowitz, R.J., 1976. Negative cooperativity among beta-adrenergic receptors in frog erythrocyte membranes. J. Biol. Chem. 251, 5007-5014.

Lin, Y.-C., Boone, M., Meuris, L., Lemmens, I., Van Roy, N., Soete, A., Reumers, J., Moisse, M., Plaisance, S., Drmanac, R., Chen, J., Speleman, F., Lambrechts, D., Van de Peer, Y., Tavernier, J., Callewaert, N., 2014. Genome dynamics of the human embryonic kidney 293 lineage in response to cell biology manipulations. Nat Commun 5.

Lutz, S., Freichel-Blomquist, A., Yang, Y., Rümenapp, U., Jakobs, K.H., Schmidt, M., Wieland, T., 2005. The Guanine Nucleotide Exchange Factor p63RhoGEF, a Specific Link between Gq/11-coupled Receptor Signaling and RhoA. J. Biol. Chem. 280, 11134-11139.

Maggi, A., U'Prichard, D.C., Enna, S.J., 1980. beta-Adrenergic regulation of alpha 2adrenergic receptors in the central nervous system. Science (80-. ). 207, 645-647. 
Maggio, R., Vogel, Z., Wess, J., 1993. Coexpression studies with mutant muscarinic/adrenergic receptors provide evidence for intermolecular "cross-talk" between G-protein-linked receptors. Proc. Natl. Acad. Sci. 90, 3103-3107.

Magni, G., Ceruti, S., 2013. P2Y purinergic receptors: New targets for analgesic and antimigraine drugs. Biochem. Pharmacol. 85, 466-477.

Malin, S.A., Molliver, D.C., 2010. Gi- and Gq-coupled ADP (P2Y) receptors act in opposition to modulate nociceptive signaling and inflammatory pain behavior. Mol. Pain 6, 21.

Margeta-Mitrovic, M., Jan, Y.N., Jan, L.Y., 2001. Function of GB1 and GB2 subunits in G protein coupling of GABAB receptors. Proc. Natl. Acad. Sci. 98, 14649-14654.

Marteau, F., Le Poul, E., Communi, D., Communi, D., Labouret, C., Savi, P., Boeynaems, J.M., Gonzalez, N.S., 2003. Pharmacological Characterization of the Human P2Y13 Receptor. Mol. Pharmacol. 64, 104-112.

Martin, S.C., Russek, S.J., Farb, D.H., 1999. Molecular Identification of the Human GABABR2: Cell Surface Expression and Coupling to Adenylyl Cyclase in the Absence of GABABR1. Mol. Cell. Neurosci. 13, 180-191.

Marucci, G., Lammi, C., Buccioni, M., Dal Ben, D., Lambertucci, C., Amantini, C., Santoni, G., Kandhavelu, M., Abbracchio, M.P., Lecca, D., Volpini, R., Cristalli, G., 2011. Comparison and optimization of transient transfection methods at human astrocytoma cell line 1321N1. Anal. Biochem. 414, 300-302.

Marullo, S., Bouvier, M., 2007. Resonance energy transfer approaches in molecular pharmacology and beyond. Trends Pharmacol. Sci. 28, 362-365.

McLawhon, R.W., Ellory, J.C., Dawson, G., 1983. Molecular size of opiate (enkephalin) receptors in neuroblastoma-glioma hybrid cells as determined by radiation inactivation analysis. J. Biol. Chem. 258, 2102-2105.

Mellon, P., Parker, V., Gluzman, Y., Maniatis, T., 1981. Identification of DNA sequences required for transcription of the human a1-globin gene in a new SV40 host-vector system. Cell 27, 279-288. 
Moore, D., Chambers, J., Waldvogel, H., Faull, R., Emson, P., 2000. Regional and cellular distribution of the P2Y1 purinergic receptor in the human brain: Striking neuronal localisation. J. Comp. Neurol. 421, 374-384.

Moore, D.J., Chambers, J.K., Wahlin, J.-P., Tan, K.B., Moore, G.B., Jenkins, O., Emson, P.C., Murdock, P.R., 2001. Expression pattern of human P2Y receptor subtypes: a quantitative reverse transcription-polymerase chain reaction study. Biochim. Biophys. Acta - Gene Struct. Expr. 1521, 107-119.

Moore, D.J., Murdock, P.R., Watson, J.M., Faull, R.L.M., Waldvogel, H.J., Szekeres, P.G., Wilson, S., Freeman, K.B., Emson, P.C., 2003. GPR105, a novel Gi/o-coupled UDPglucose receptor expressed on brain glia and peripheral immune cells, is regulated by immunologic challenge: possible role in neuroimmune function. Mol. Brain Res. 118, 10-23.

Moriyama, T., lida, T., Kobayashi, K., Higashi, T., Fukuoka, T., Tsumura, H., Leon, C., Suzuki, N., Inoue, K., Gachet, C., Noguchi, K., Tominaga, M., 2003. Possible Involvement of P2Y2 Metabotropic Receptors in ATP-Induced Transient Receptor Potential Vanilloid Receptor 1-Mediated Thermal Hypersensitivity. J. Neurosci. 23, 6058-6062.

Morrow, G.B., Nicholas, R.A., Kennedy, C., 2014. UTP is not a biased agonist at human P2Y(11) receptors. Purinergic Signal. 10, 581-585.

Mülhardt, C., Beese, E.W., 2007. 4 - The Polymerase Chain Reaction. In: Molecular Biology and Genomics. Academic Press, Burlington, pp. 65-94.

Mundell, S.J., Benovic, J.L., 2000. Selective Regulation of Endogenous G Protein-coupled Receptors by Arrestins in HEK293 Cells. J. Biol. Chem. 275, 12900-12908.

Murthy, K.S., Makhlouf, G.M., 1998. Coexpression of Ligand-gated P2X and G Proteincoupled P2Y Receptors in Smooth Muscle: PREFERENTIAL ACTIVATION OF P2Y RECEPTORS COUPLED TO PHOSPHOLIPASE C (PLC)- $\beta 1$ VIA Gaq/11 AND TO PLC- $\beta 3$ VIA GßYi3. J. Biol. Chem. 273, 4695-4704.

Nakata, H., Suzuki, T., Namba, K., Oyanagi, K., 2010. Dimerization of G protein-coupled purinergic receptors: increasing the diversity of purinergic receptor signal responses and receptor functions. J. Recept. Signal Transduct. 30, 337-346. 
Naughton, R., 2014. Investigation of P2Y1 and P2Y12 receptor heterodimerisation (THESIS). SIPBS. The University of Strathclyde, Glasgow, UK.

Naughton, R., Paton, K., Bushell, T., Kennedy, C., 2014. Evidence that human P2Y1 and P2Y12 receptors form functional heterodimers. In: BPS 5th Focused Meeting on Cell Signalling, Proceedings of the British Pharmacological Society. University of Leicester, Leicester, UK.

Ng, S.Y.L., Lee, L.T.O., Chow, B.K.C., 2013. Receptor oligomerization: from early evidence to current understanding in class B GPCRs. Front. Endocrinol. (Lausanne). 3.

Nylander, S., Schulz, R., 2016. Effects of P2Y12 receptor antagonists beyond platelet inhibition - comparison of ticagrelor with thienopyridines. Br. J. Pharmacol. 173, 11631178.

O'Connor, S., Montalescot, G., Collet, J.-P., 2011. The P2Y(12) receptor as a target of antithrombotic drugs. Purinergic Signal. 7, 325-332.

Okada, M., Nakagawa, T., Minami, M., Satoh, M., 2002. Analgesic Effects of Intrathecal Administration of P2Y Nucleotide Receptor Agonists UTP and UDP in Normal and Neuropathic Pain Model Rats. J. Pharmacol. Exp. Ther. 303, 66-73.

Ossipov, M.H., Dussor, G.O., Porreca, F., 2010. Central modulation of pain. J. Clin. Invest. 120, 3779-3787.

Overton, M.C., Blumer, K.J., 2002. Use of fluorescence resonance energy transfer to analyze oligomerization of G-protein-coupled receptors expressed in yeast. Methods $27,324-332$.

Pacheco, M.A., Jope, R.S., 1997. Comparison of [3H]Phosphatidylinositol and [3H]Phosphatidylinositol 4,5-Bisphosphate Hydrolysis in Postmortem Human Brain Membranes and Characterization of Stimulation by Dopamine D1 Receptors. J. Neurochem. 69, 639-644.

Palczewski, K., 2010. Oligomeric forms of G protein-coupled receptors (GPCRs). Trends Biochem. Sci. 35, 595-600. 
Palmer, R.K., Boyer, J.L., Schachter, J.B., Nicholas, R.A., Harden, T.K., 1998. Agonist Action of Adenosine Triphosphates at the Human P2Y1 Receptor. Mol. Pharmacol. 54, 1118-1123.

Park, P.S.H., Wells, J.W., 2004. Oligomeric potential of the M2 muscarinic cholinergic receptor. J. Neurochem. 90, 537-548.

Parr, C.E., Sullivan, D.M., Paradiso, A.M., Lazarowski, E.R., Burch, L.H., Olsen, J.C., Erb, L., Weisman, G.A., Boucher, R.C., Turner, J.T., 1994. Cloning and expression of a human P2U nucleotide receptor, a target for cystic fibrosis pharmacotherapy. Proc. Natl. Acad. Sci. 91, 3275-3279.

Persani, L., Calebiro, D., Bonomi, M., 2007. Technology Insight: modern methods to monitor protein-protein interactions reveal functional TSH receptor oligomerization. Nat Clin Pr. End Met 3, 180-190.

Pin, J.-P., Neubig, R., Bouvier, M., Devi, L., Filizola, M., Javitch, J.A., Lohse, M.J., Milligan, G., Palczewski, K., Parmentier, M., Spedding, M., 2007. International Union of Basic and Clinical Pharmacology. LXVII. Recommendations for the Recognition and Nomenclature of G Protein-Coupled Receptor Heteromultimers. Pharmacol. Rev. 59, $5-13$.

Pinard, A., Seddik, R., Bettler, B., Thomas, P.B., 2010. GABAB Receptors: Physiological Functions and Mechanisms of Diversity. In: Advances in Pharmacology. Academic Press, pp. 231-255.

Prezeau, L., Rives, M.-L., Comps-Agrar, L., Maurel, D., Kniazeff, J., Pin, J.-P., 2010. Functional crosstalk between GPCRs: with or without oligomerization. Curr. Opin. Pharmacol. 10, 6-13.

Puretic, M.B., Demarin, V., 2012. Neuroplasticity mechanisms in the pathophysiology of chronic pain. Acta Clin Croat 51, 425-429.

Ramsay, D., Kellett, E., McVey, M., Rees, S., Milligan, G., 2002. Homo- and heterooligomeric interactions between G-protein-coupled receptors in living cells monitored by two variants of bioluminescence resonance energy transfer (BRET): hetero-oligomers between receptor subtypes form more efficiently than between less. Biochem. J. 365, $429-440$. 
Rang, H.P., Dale, M.M., Ritter, J., Flower, R., Henderson, G., 2011. Rang and Dale's pharmacology, 7th ed. Elsevier/Churchill Livingstone, Edinburgh; New York.

Rashid, A.J., So, C.H., Kong, M.M.C., Furtak, T., El-Ghundi, M., Cheng, R., O’Dowd, B.F., George, S.R., 2007. D1-D2 dopamine receptor heterooligomers with unique pharmacology are coupled to rapid activation of $\mathrm{Gq} / 11$ in the striatum. Proc. Natl. Acad. Sci. 104, 654-659.

Richardson, J.D., Vasko, M.R., 2002. Cellular Mechanisms of Neurogenic Inflammation. J. Pharmacol. Exp. Ther. 302, 839-845.

Ringkamp, M., Raja, S.N., Campbell, J.N., Meyer, R.A., 2013. Peripheral Mechanisms of Cutaneous Nociception. Wall \& Melzack's Textbook of Pain.

Rios, C.D., Jordan, B.A., Gomes, I., Devi, L.A., 2001. G-protein-coupled receptor dimerization: modulation of receptor function. Pharmacol. Ther. 92, 71-87.

Salim, K., Fenton, T., Bacha, J., Urien-Rodriguez, H., Bonnert, T., Skynner, H.A., Watts, E., Kerby, J., Heald, A., Beer, M., McAllister, G., Guest, P.C., 2002. Oligomerization of Gprotein-coupled Receptors Shown by Selective Co-immunoprecipitation. J. Biol. Chem. 277, 15482-15485.

Sanger, F., Nicklen, S., Coulson, A.R., 1977. DNA sequencing with chain-terminating inhibitors. Proc. Natl. Acad. Sci. U. S. A. 74, 5463-5467.

Satoh, J., Tosaki, Y., Sakai, K., Yanaizu, M., Kino, Y., 2016. P2Y12 expression on microglia in the human brain. Clin. Exp. Neuroimmunol. 7, 366-368.

Savi, P., Zachayus, J.-L., Delesque-Touchard, N., Labouret, C., Hervé, C., Uzabiaga, M.-F., Pereillo, J.-M., Culouscou, J.-M., Bono, F., Ferrara, P., Herbert, J.-M., 2006. The active metabolite of Clopidogrel disrupts P2Y12 receptor oligomers and partitions them out of lipid rafts. Proc. Natl. Acad. Sci. U. S. A. 103, 11069-11074.

Schachter, J.B., Sromek, S.M., Nicholas, R.A., Harden, T.K., 1997. HEK293 human embryonic kidney cells endogenously express the P2Y1 and P2Y2 receptors. Neuropharmacology 36, 1181-1187. 
Schäfer, R., Sedehizade, F., Welte, T., Reiser, G., 2003. ATP- and UTP-activated P2Y receptors differently regulate proliferation of human lung epithelial tumor cells. Am. J. Physiol. - Lung Cell. Mol. Physiol. 285, L376.

Schicker, K., Hussl, S., Chandaka, G.K., Kosenburger, K., Yang, J.-W., Waldhoer, M., Sitte, H.H., Boehm, S., 2009. A membrane network of receptors and enzymes for adenine nucleotides and nucleosides. Biochim. Biophys. Acta - Mol. Cell Res. 1793, 325-334.

Shi, C., Shen, X., Niu, S., Ma, C., 2015. Innate Reverse Transcriptase Activity of DNA Polymerase for Isothermal RNA Direct Detection. J. Am. Chem. Soc. 137, 1380413806.

Shirasaki, H., Kanaizumi, E., Seki, N., Kikuchi, M., Himi, T., 2013. Expression and Localization of Purinergic P2Y12 Receptor in Human Nasal Mucosa. Allergol. Int. 62, 239-244.

Shrestha, S.S., Parmar, M., Kennedy, C., Bushell, T.J., 2010. Two-pore potassium ion channels are inhibited by both $\mathrm{Gq} / 11$ - and Gi-coupled P2Y receptors. Mol. Cell. Neurosci. 43, 363-369.

Simon, J., Filippov, A.K., Göransson, S., Wong, Y.H., Frelin, C., Michel, A.D., Brown, D.A., Barnard, E.A., 2002. Characterization and Channel Coupling of the P2Y12 Nucleotide Receptor of Brain Capillary Endothelial Cells. J. Biol. Chem. 277, 31390-31400.

So, C.H., Varghese, G., Curley, K.J., Kong, M.M.C., Alijaniaram, M., Ji, X., Nguyen, T., O'Dowd, B.F., George, S.R., 2005. D1 and D2 Dopamine Receptors Form Heterooligomers and Cointernalize after Selective Activation of Either Receptor. Mol. Pharmacol. 68, 568-578.

Steeds, C.E., 2013. The anatomy and physiology of pain. Surg. 31, 49-53.

Suplat, D., Krzemiński, P., Pomorski, P., Barańska, J., 2007. P2Y(1) and P2Y(12) receptor cross-talk in calcium signalling: Evidence from nonstarved and long-term serumdeprived glioma C6 cells. Purinergic Signal. 3, 221-230.

Suzuki, T., Namba, K., Tsuga, H., Nakata, H., 2006. Regulation of pharmacology by heterooligomerization between $\mathrm{A} 1$ adenosine receptor and $\mathrm{P} 2 \mathrm{Y} 2$ receptor. Biochem. Biophys. Res. Commun. 351, 559-565. 
Suzuki, T., Obara, Y., Moriya, T., Nakata, H., Nakahata, N., 2011. Functional interaction between purinergic receptors: effect of ligands for $\mathrm{A} 2 \mathrm{~A}$ and $\mathrm{P} 2 \mathrm{Y} 12$ receptors on $\mathrm{P} 2 \mathrm{Y} 1$ receptor function. FEBS Lett. 585, 3978-3984.

Szidonya, L., Cserző, M., Hunyady, L., 2008. Dimerization and oligomerization of G-proteincoupled receptors: debated structures with established and emerging functions. J. Endocrinol. 196, 435-453.

Tang, T.-S., Bezprozvanny, I., 2004. Dopamine Receptor-mediated Ca2+ Signaling in Striatal Medium Spiny Neurons. J. Biol. Chem. 279, 42082-42094.

Tate, R., 2016. Gel results (15/08/2016).

Teitler, M., Klein, M.T., 2012. A new approach for studying GPCR dimers: Drug-induced inactivation and reactivation to reveal GPCR dimer function in vitro, in primary culture, and in vivo. Pharmacol. Ther. 133, 205-217.

Thienhaus, O., Cole, B.E., 2002. The Classification of Pain. In: Weiner, R.S. (Ed.), Pain Management: A Practical Guide for Clinicians. CRC Press, Boca Raton, Florida, p. 28.

Thomas, P., Smart, T.G., 2005. HEK293 cell line: A vehicle for the expression of recombinant proteins. J. Pharmacol. Toxicol. Methods 51, 187-200.

Tozaki-Saitoh, H., Tsuda, M., Miyata, H., Ueda, K., Kohsaka, S., Inoue, K., 2008. P2Y12 Receptors in Spinal Microglia Are Required for Neuropathic Pain after Peripheral Nerve Injury. J. Neurosci. 28, 4949-4956.

Tsuda, M., Masuda, T., Tozaki-Saitoh, H., Inoue, K., 2013. P2X4 receptors and neuropathic pain. Front. Cell. Neurosci. 7.

Tung, E.K.K., Choi, R.C.Y., Siow, N.L., Jiang, J.X.S., Ling, K.K.Y., Simon, J., Barnard, E.A., Tsim, K.W.K., 2004. P2Y2 Receptor Activation Regulates the Expression of Acetylcholinesterase and Acetylcholine Receptor Genes at Vertebrate Neuromuscular Junctions. Mol. Pharmacol. 66, 794-806.

Üçeyler, N., Sommer, C., 2006. Wallerian degeneration and neuropathic pain. Drug Discov. Today Dis. Mech. 3, 351-356. 
Undie, A.S., Weinstock, J., Sarau, H.M., Friedman, E., 1994. Evidence for a Distinct D1 Like Dopamine Receptor that Couples to Activation of Phosphoinositide Metabolism in Brain. J. Neurochem. 62, 2045-2048.

van Hecke, O., Torrance, N., Smith, B.H., 2013. Chronic pain epidemiology and its clinical relevance. Br. J. Anaesth. 111, 13-18.

Velázquez, B., Garrad, R.C., Weisman, G.A., González, F.A., 2000. Differential agonistinduced desensitization of P2Y2 nucleotide receptors by ATP and UTP. Mol. Cell. Biochem. 206, 75-89.

Venter, J.C., Horne, P., Eddy, B., Greguski, R., Fraser, C.M., 1984. Alpha 1-adrenergic receptor structure. Mol. Pharmacol. 26, 196-205.

Vischer, H.F., Watts, A.O., Nijmeijer, S., Leurs, R., 2011. G protein-coupled receptors: walking hand-in-hand, talking hand-in-hand? Br. J. Pharmacol. 163, 246-260.

Voscopoulos, C., Lema, M., 2010. When does acute pain become chronic? Br. J. Anaesth. 105, i69-i85.

Waldo, G.L., Harden, T.K., 2004. Agonist Binding and Gq-Stimulating Activities of the Purified Human P2Y1 Receptor. Mol. Pharmacol. 65, 426-436.

Wang, D., Sun, X., Bohn, L.M., Sadée, W., 2005. Opioid Receptor Homo- and Heterodimerization in Living Cells by Quantitative Bioluminescence Resonance Energy Transfer. Mol. Pharmacol. 67, 2173-2184.

Wang, H.Y., Undie, A.S., Friedman, E., 1995. Evidence for the coupling of Gq protein to D1like dopamine sites in rat striatum: possible role in dopamine-mediated inositol phosphate formation. Mol. Pharmacol. 48, 988-994.

Weisman, G.A., Yu, N., Liao, Z., Gonzalez, F., Erb, L., Seye, C.I., 2006. P2 receptors in health and disease. Biotechnol Genet Eng Rev 22, 171-195.

Werry, T.D., Christie, M.I., Dainty, I.A., Wilkinson, G.F., Willars, G.B., 2002. Ca2+ signalling by recombinant human CXCR2 chemokine receptors is potentiated by P2Y nucleotide receptors in HEK cells. Br. J. Pharmacol. 135, 1199-1208. 
White, J.H., Wise, A., Main, M.J., Green, A., Fraser, N.J., Disney, G.H., Barnes, A.A., Emson, P., Foord, S.M., Marshall, F.H., 1998. Heterodimerization is required for the formation of a functional GABAB receptor. Nature 396, 679-682.

Wirkner, K., Schweigel, J., Gerevich, Z., Franke, H., Allgaier, C., Barsoumian, E.L., Draheim, $\mathrm{H}$., Illes, P., 2004. Adenine nucleotides inhibit recombinant $\mathrm{N}$-type calcium channels via G protein-coupled mechanisms in HEK 293 cells; involvement of the P2Y(13) receptortype. Br. J. Pharmacol. 141, 141-151.

Wun, T., Soulieres, D., Frelinger, A.L., Krishnamurti, L., Novelli, E.M., Kutlar, A., Ataga, K.I., Knupp, C.L., McMahon, L.E., Strouse, J.J., Zhou, C., Heath, L.E., Nwachuku, C.E., Jakubowski, J.A., Riesmeyer, J.S., Winters, K.J., 2013. A double-blind, randomized, multicenter phase 2 study of prasugrel versus placebo in adult patients with sickle cell disease. J. Hematol. Oncol. 6, 17.

Wypych, D., Pomorski, P., 2012. P2Y1 nucleotide receptor silencing and its effect on glioma C6 calcium signaling. Acta Biochim Pol 59, 711-717.

Wypych, D., Barańska, J., 2013. Cross-Talk in Nucleotide Signaling in Glioma C6 Cells. In: Barańska, J. (Ed.), Glioma Signaling. Springer Netherlands, Dordrecht, pp. 31-59.

Yoshioka, K., Saitoh, O., Nakata, H., 2002. Agonist-promoted heteromeric oligomerization between adenosine A1 and P2Y1 receptors in living cells. FEBS Lett. 523, 147-151.

Yoshioka, K., Saitoh, O., Nakata, H., 2001. Heteromeric association creates a P2Y-like adenosine receptor. Proc. Natl. Acad. Sci. 98, 7617-7622.

Zhang, K., Zhang, J., Gao, Z.-G., Zhang, D., Zhu, L., Han, G.W., Moss, S.M., Paoletta, S., Kiselev, E., Lu, W., Fenalti, G., Zhang, W., Müller, C.E., Yang, H., Jiang, H., Cherezov, V., Katritch, V., Jacobson, K.A., Stevens, R.C., Wu, B., Zhao, Q., 2014. Structure of the human P2Y(12) receptor in complex with an antithrombotic drug. Nature 509, 115-118.

Zhong, X., Kriz, R., Seehra, J., Kumar, R., 2004. N-linked glycosylation of platelet P2Y12 ADP receptor is essential for signal transduction but not for ligand binding or cell surface expression. FEBS Lett. 562, 111-117.

Zhu, H., Yu, Y., Zheng, L., Wang, L., Li, C., Yu, J., Wei, J., Wang, C., Zhang, J., Xu, S., Wei, X., Cui, W., Wang, Q., Chen, X., 2015. Chronic inflammatory pain upregulates 
expression of P2Y2 receptor in small-diameter sensory neurons. Metab. Brain Dis. 110. 